\title{
Chemistry of $\mathrm{OH}$ in remote clouds and its role in the production of formic acid and peroxymonosulfate
}

\section{Citation}

Jacob, Daniel J. 1986. "Chemistry of $\mathrm{OH}$ in Remote Clouds and Its Role in the Production of Formic Acid and Peroxymonosulfate." Journal of Geophysical Research 91 (D9): 9807. doi:10.1029/jd091id09p09807.

\section{Published Version}

doi:10.1029/JD091iD09p09807

\section{Permanent link}

http://nrs.harvard.edu/urn-3:HUL.InstRepos:14121762

\section{Terms of Use}

This article was downloaded from Harvard University's DASH repository, and is made available under the terms and conditions applicable to Other Posted Material, as set forth at http:// nrs.harvard.edu/urn-3:HUL.InstRepos:dash.current.terms-of-use\#LAA

\section{Share Your Story}

The Harvard community has made this article openly available.

Please share how this access benefits you. Submit a story.

Accessibility 


\title{
Chemistry of $\mathrm{OH}$ in Remote Clouds and Its Role in the Production of Formic Acid and Peroxymonosulfate
}

\author{
DANIEL J. JACOB
}

Center for Earth and Planetary Physics, Harvard Univerity, Cambridge, Massachusetts

\begin{abstract}
The chemistry of $\mathrm{OH}$ in a remote nonprecipitating tropical cloud is studied with a coupled gas-phase and aqueous-phase chemical model. The model takes into account the radial dependence of the concentrations of short-lived aqueous-phase species, in particular, $\mathrm{O}_{3}(\mathrm{aq})$ and $\mathrm{OH}(\mathrm{aq})$. The radical $\mathrm{OH}(\mathrm{aq})$ is produced rapidly by the aqueous-phase reactions $\mathrm{O}_{2}{ }^{-}+\mathrm{O}_{3}$ and $\mathrm{H}_{2} \mathrm{O}_{2}+h v$ and is removed primarily by oxidation of $\mathrm{H}_{2} \mathrm{C}(\mathrm{OH})_{2}, \mathrm{H}_{2} \mathrm{O}_{2}$, and $\mathrm{HCOO}^{-}$. Gas-droplet transfer of $\mathrm{OH}$ must be modeled as a reversible process, that is, the droplets cannot be assumed to be diffusion-limited $\mathrm{OH}(\mathrm{g})$ sinks. A strong $\mathrm{OH}(\mathrm{aq})$ concentration gradient exists between the surface and the interior of the droplets. The concentration of $\mathrm{OH}(\mathrm{aq})$ is strongly dependent on $p \mathrm{H}$ but is only weakly dependent on the sticking coefficient, the droplet radius, or the liquid water content of the cloud. Formic acid is rapidly produced by the aqueous-phase reaction $\mathrm{H}_{2} \mathrm{C}(\mathrm{OH})_{2}+\mathrm{OH}$, but $\mathrm{HCOO}^{-}$is in turn rapidly oxidized by $\mathrm{OH}(\mathrm{aq})$. The $\mathrm{HCOOH}$ concentration in cloud is shown to be strongly dependent on cloud water $p \mathrm{H}$; clouds with $p \mathrm{H}$ greater than 5 are not efficient $\mathrm{HCOOH}$ sources. A novel mechanism is proposed for the oxidation of $\mathrm{S}(\mathrm{IV})$ by $\mathrm{OH}(\mathrm{aq})$. The main product is predicted to be $\mathrm{HSO}_{5}{ }^{-}$(peroxymonosulfate). Peroxymonosulfate appears to be stable in remote clouds and could contribute a large fraction of total cloud water sulfur.
\end{abstract}

\section{INTRODUCTION}

The hydroxyl radical $\mathrm{OH}$ plays a central role in tropospheric chemistry. Reaction with $\mathrm{OH}$ in the gas phase constitutes the primary sink for a number of atmospheric species, such as $\mathrm{CH}_{4}$ and $\mathrm{CO}$. Oxidation of $\mathrm{SO}_{2}$ and $\mathrm{NO}_{2}$ by $\mathrm{OH}(\mathrm{g})$ plays an important role in producing $\mathrm{H}_{2} \mathrm{SO}_{4}$ and $\mathrm{HNO}_{3}$, the main components of acidic precipitation [Calvert and Stockwell, 1984]. The chemistry of $\mathrm{OH}(\mathrm{g})$ in the remote troposphere under cloud-free conditions has been studied in detail [Chameides and Tan, 1981; Logan et al., 1981; National Research Council, 1984], but much less attention has been paid to the chemistry of $\mathrm{OH}$ in clouds. Complications to the chemistry arise in a cloud because of gas-droplet transfer and aqueous-phase reactions. The aqueous-phase radical $\mathrm{OH}(\mathrm{aq})$ is a very strong oxidant; reactions of $\mathrm{OH}(\mathrm{aq})$ in cloud droplets may have important implications for the composition of cloud water and, more generally, for the chemical transformations of atmospheric species. The object of this paper is to provide a model description of the chemistry of $\mathrm{OH}(\mathrm{g})$ and $\mathrm{CH}(\mathrm{aq})$ in clouds and to discuss two globally important aqueous-phase processes involving $\mathrm{OH}(\mathrm{aq})$ : the production of $\mathrm{HCOOH}$ and the oxidation of S(IV).

The chemistry of $\mathrm{OH}$ is tied to that of $\mathrm{HO}_{2}$ and $\mathrm{H}_{2} \mathrm{O}_{2}$, and it is convenient to group these three species into a chemical family: odd hydrogen (odd $\mathrm{H}$ ). The odd $\mathrm{H}$ species are interconverted in the gas phase by a number of fast reactions, which constitute the odd $\mathrm{H}$ cycle [cf. Logan et al., 1981]. Cloud formation perturbs the gas-phase odd $\mathrm{H}$ cycle as a result of the scavenging of water-soluble species by the droplets. The odd $\mathrm{H}$ species are all soluble in water and cycle rapidly in the aqueous phase by reactions analogous to the reactions in the gas phase [Chameides and Davis, 1982; Chameides, 1984; Schwartz, 1984]. The radical OH(aq) produced in this aqueous-phase odd $\mathrm{H}$ cycle interacts with $\mathrm{OH}(\mathrm{g})$ by gas-droplet transfer and oxidizes reduced species in the

Copyright 1986 by the American Geophysical Union.

Paper number 6D0268.

0148-0227/86/006D-0268\$05.00 aqueous phase at rates often approaching the diffusion limit [Anbar and Neta, 1967].

The reaction of $\mathrm{OH}(\mathrm{aq})$ with hydrated formaldehyde, $\mathrm{H}_{2} \mathrm{C}(\mathrm{OH})_{2}$, produces $\mathrm{HCOOH}$ [Chameides, 1984]. Formic acid has been identified as an important contributor to the acidity of precipitation at remote sites [Keene et al., 1983]. Aqueous-phase production of $\mathrm{HCOOH}$ by the above reaction is considerably more rapid than gas-phase production by breakup of double-bonded hydrocarbons [Stockwell and Calvert, 1983] or by oxidation of $\mathrm{CH}_{2} \mathrm{O}(\mathrm{g})$ by $\mathrm{HO}_{2}(\mathrm{~g})$ [Su et al., 1979]. Because of this aqueous-phase source, clouds have been proposed as a major global source of $\mathrm{HCOOH}$ in the troposphere [Chameides, 1984; Adewuyi et al., 1984]. However, cloud droplets are also efficient sinks for $\mathrm{HCOOH}$ because of the very rapid oxidation of $\mathrm{HCOO}^{-}$by $\mathrm{OH}(\mathrm{aq})$. A major point of this paper will be to show that the concentration of $\mathrm{HCOOH}$ in cloud is strongly dependent on the cloud water $p \mathrm{H}$.

Another important process involving $\mathrm{OH}(\mathrm{aq})$ is the oxidation of $\mathrm{SO}_{2}$. Scavenging of $\mathrm{SO}_{2}$ by cloud droplets, followed by aqueous-phase oxidation of S(IV), has been suggested to be the dominant mechanism for global production of $\mathrm{H}_{2} \mathrm{SO}_{4}$ i:i the troposphere [Hegg, 1985]. The most important aqueousphase S(IV) oxidants in remote clouds are thought to be $\mathrm{H}_{2} \mathrm{O}_{2}(\mathrm{aq}), \mathrm{O}_{3}(\mathrm{aq})$, and $\mathrm{OH}(\mathrm{aq})$ [Chameides, 1984]. The oxidation reactions with $\mathrm{H}_{2} \mathrm{O}_{2}(\mathrm{aq})$ and $\mathrm{O}_{3}(\mathrm{aq})$ are well understood [McArdle and Hoffmann, 1983; Hoigne et al., 1985; Hoffmann, $1986]$, but the mechanism of the chain reaction initiated by $\mathrm{OH}(\mathrm{aq})$ attack on S(IV) is more uncertain. McElroy [1986] has recently pointed out major faults in the mechanisms assumed by previous cloud chemistry models. I will develop here a novel mechanism for the oxidation of S(IV) by $\mathrm{OH}(\mathrm{aq})$ which is consistent with currently available kinetic data. A major feature of this mechanism is that the chain carrier intermediate $\mathrm{SO}_{5}{ }^{-}$may oxidize other species besides $\mathrm{S}$ (IV), thereby terminating the oxidation chain. The main product is predicted to be $\mathrm{HSO}_{5}{ }^{-}$(peroxymonosulfate). I will argue that $\mathrm{HSO}_{5}{ }^{-}$may be a stable sulfur species in remote clouds and may constitute an important fraction of total cloud water sulfur. 
The discussion will be based on a detailed gas-phase/ aqueous-phase chemical model simulating the chemistry of a nonprecipitating cloud in the remote troposphere. An innovative feature of the model is its treatment of the radial dependence of the concentrations of short-lived aqueous-phase species, in particular, $\mathrm{OH}(\mathrm{aq})$. The concentration of $\mathrm{OH}(\mathrm{aq})$ at the droplet surface may differ considerably from that in the droplet interior, and this has important implications in determining the $\mathrm{OH}(\mathrm{aq})$ volatilization flux. Previous models of cloud water chemistry have assumed that the droplets constitute diffusion-limited sinks for $\mathrm{OH}(\mathrm{g})$ [Chameides and Davis, 1982; Chameides, 1984; Seigneur et al., 1985]; however, $\mathrm{OH}(\mathrm{g})$ is only moderately soluble in water, with a Henry's law constant of about $20 \mathrm{M} \mathrm{atm}^{-1}$. Therefore gas-droplet transfer of $\mathrm{OH}$ must be modeled as a reversible process in which both the absorption flux and the volatilization flux are considered. An analytical solution for the $\mathrm{OH}(\mathrm{aq})$ radial concentration profile will be presented, which can easily be incorporated into complex cloud chemistry models.

\section{Cloud Chemistry Model}

\section{Cloud Formation}

Cloud formation is simulated by isobaric cooling of a boundary layer air parcel in a tropical spring atmosphere. The standard model conditions are listed in Tables $1 a$ and $1 b$. The temperature of the air parcel is assumed to drop instantaneously from its initial value $(297 \mathrm{~K})$ down to a value at which a specified liquid water content $\left(5 \times 10^{-7} \mathrm{vol} / \mathrm{vol}\right.$ in the standard simulation) is produced by condensation on preexisting nuclei. The cloud droplets are assumed to be monodisperse and to reach instantaneously a droplet radius fixed by input to the model (10 $\mu \mathrm{m}$ in the standard simulation). The droplets do not precipitate and follow the air parcel with negligible inertia.

The radiation field is initially calculated for clear noontime conditions, with the parameters of Table $1 a$. Cloud formation enhances radiation in the upper region of the cloud (because of scattering from below) and weakens radiation in the lower region of the cloud (because of increased optical depth). An intermediate level is considered where cloud formation causes no net change in the radiation field; sensitivity analyses are conducted to examine the effect of insolation changes.

TABLE 1a. Standard Model Conditions: Model Parameters

\begin{tabular}{lcc}
\hline \multicolumn{1}{c}{ Parameter } & Value \\
\hline Latitude & $15^{\circ}$ \\
Solar declination & $0^{\circ}$ \\
Suface albedo & 0.07 \\
Temperature & \\
$\quad$ Before cloud formation & $297 \mathrm{~K}$ \\
$\quad$ In cloud & $293 \mathrm{~K}$ \\
Relative humidity & & \\
$\quad$ Before cloud formation & $80 \%$ \\
$\quad$ In cloud & $100 \%$ \\
Liquid water content & $0.5 \mathrm{~g} \mathrm{~m}^{-3}\left(5 \times 10^{-7} \mathrm{vol} / \mathrm{vol}\right)$ \\
Droplet radius & $10 \mu \mathrm{m}$ \\
Sticking coefficient & 0.1 \\
Condensation nuclei & $7 \times 10^{-9}$ moles m ${ }^{-3} \mathrm{NaCl},{ }^{a}$ \\
& [from Gillette and Blifford, 1971] \\
\hline
\end{tabular}

Radiation field is calculated for clear-sky conditions. Values for vertical columns of ozone, water vapor, and aerosol are from Logan et al. [1981].

${ }^{a} \mathrm{H}^{+}$or $\mathrm{OH}^{-}$are added in $\mathrm{pH}$ sensitivity calculations.
TABLE $1 b$. Standard Model Conditions: Initial Concentrations of Gas-Phase Species Before Cloud Formation

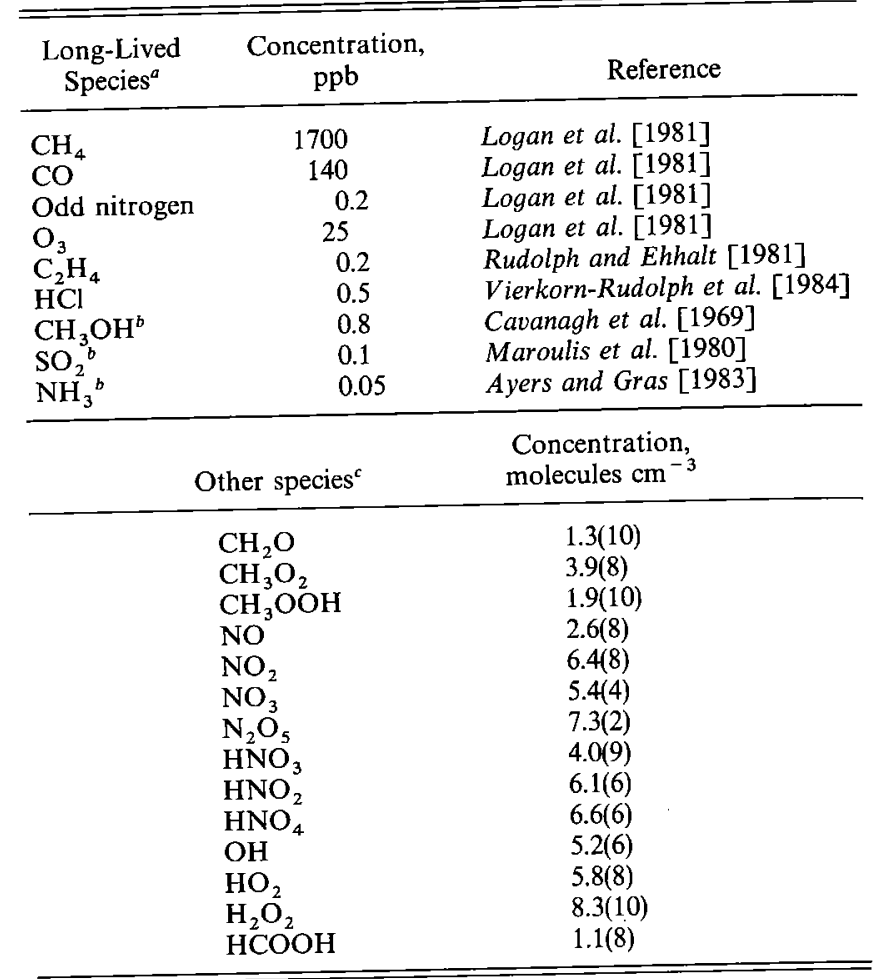

Read $1.3(10)$ as $1.3 \times 10^{10}$.

${ }^{a}$ Concentrations of these species are held at a fixed value throughout the simulation.

${ }^{b}$ Concentrations of these species are held at a fixed value only in the absence of cloud (see text).

'Initial concentrations of these species are calculated from the concentrations of long-lived species by iteration of the gas-phase mechanism over successive diurnal cycles (see text).

\section{Gas-Phase Chemical Mechanism}

A standard gas-phase mechanism for the $\mathrm{H}_{x} \mathrm{O}_{y}$ $\mathrm{N}_{x} \mathrm{O}_{y}-\mathrm{CH}_{4}-\mathrm{CO}$ system is used, which includes over 100 reactions. The reader is referred to Logan et al. [1981] for a detailed discussion of this mechanism. Rate constants have been updated following the recommendations of the Jet Propulsion Laboratory [1983]. The radical $\mathrm{OH}(\mathrm{g})$ is produced by

(RG1)

$$
\mathrm{O}_{3}+h v \rightarrow \mathrm{O}_{2}+\mathrm{O}\left({ }^{1} D\right)
$$

followed by

(RG2)

$$
\mathrm{O}\left({ }^{1} D\right)+\mathrm{H}_{2} \mathrm{O} \rightarrow 2 \mathrm{OH}
$$

and by

$$
\mathrm{H}_{2} \mathrm{O}_{2}+h v \rightarrow 2 \mathrm{OH}
$$

Reactions of $\mathrm{HO}_{2}(\mathrm{~g})$ with $\mathrm{O}_{3}$ and $\mathrm{NO}$ may also be important:

$$
\begin{aligned}
& \mathrm{HO}_{2}+\mathrm{O}_{3} \rightarrow \mathrm{OH}+2 \mathrm{O}_{2} \\
& \mathrm{HO}_{2}+\mathrm{NO} \rightarrow \mathrm{OH}+\mathrm{NO}_{2}
\end{aligned}
$$

Removal of $\mathrm{OH}(\mathrm{g})$ is mostly by reactions with $\mathrm{CH}_{4}$ and $\mathrm{CO}$ :

$$
\begin{gathered}
\mathrm{CH}_{4}+\mathrm{OH} \stackrel{\stackrel{\mathrm{O}_{2}}{\rightarrow} \mathrm{CH}_{3} \mathrm{O}_{2}+\mathrm{H}_{2} \mathrm{O}}{\mathrm{O}}+\stackrel{\mathrm{O}_{2}}{\rightarrow} \mathrm{CO}_{2}+\mathrm{HO}_{2}
\end{gathered}
$$

where it is assumed that $\mathrm{CH}_{3}(\mathrm{~g})$ and $\mathrm{H}(\mathrm{g})$ radicals react instantaneously with $\mathrm{O}_{2}$ to give the indicated products. 
TABLE $2 a$. Aqueous-Phase Chemistry: Henry's Law Constants

\begin{tabular}{|c|c|c|c|c|}
\hline $\begin{array}{l}\text { Reaction } \\
\text { No. }\end{array}$ & Species & $\begin{array}{l}K_{\mathrm{H}, 298} \\
M \mathrm{~atm}^{-1}\end{array}$ & $\begin{array}{c}\Delta \mathrm{H}_{298}{ }^{\circ}, \\
\mathrm{kcal}^{-1} \\
\mathrm{~mol}^{-1}\end{array}$ & Reference \\
\hline (H1) & $\mathrm{O}_{3}$ & $1.10(-2)$ & -4.8 & Hoffmann and Calvert [1985] \\
\hline$(\mathrm{H} 2)$ & $\mathrm{OH}^{3}$ & $2.5(1)$ & $-10.5^{a, b}$ & $\begin{array}{l}\text { National Bureau of Standards [1971]; } \\
\text { Klaning et al. }[1985]\end{array}$ \\
\hline (H3) & $\mathrm{HO}_{2}$ & 2.(3) & $-13.2^{a}$ & Schwartz [1984] \\
\hline (H4) & $\mathrm{H}_{2} \mathrm{O}_{2}$ & $7.4(4)$ & -13.2 & Lind and Kok [1986] \\
\hline (H5) & $\mathrm{CH}_{3} \mathrm{O}_{2}$ & $6 .(0)^{a}$ & $-11.2^{a}$ & see footnote ${ }^{c}$ \\
\hline (H6) & $\mathrm{CH}_{3} \mathrm{OOH}$ & $2.2(2)$ & -11.2 & Lind and Kok [1986] \\
\hline (H7) & $\mathrm{CH}_{3} \mathrm{OH}$ & $2.2(2)$ & -9.8 & Snider and Dawson [1985] \\
\hline (H8) & $\mathrm{CH}_{2} \mathrm{O}$ & $6.3(3)^{d}$ & -12.9 & Ledbury and Blair $[1925]$ \\
\hline (H9) & $\mathrm{HCOOH}$ & $3.7(3)^{e}$ & -11.4 & Latimer $[1952]$ \\
\hline (H10) & $\mathrm{CO}_{2}$ & $3.4(-2)$ & -4.85 & Hoffman and $\vec{C}$ alvert [1985] \\
\hline (H11) & NO & $1.9(-3)$ & -2.94 & Schwartz and White [1981] \\
\hline (H12) & $\mathrm{HNO}_{2}$ & $4.9(1)$ & -9.5 & Schwartz and White [1981] \\
\hline (H13) & $\mathrm{NO}_{2}$ & $1.2(-2)$ & -5.0 & Schwartz and White [1981] \\
\hline (H14) & $\mathrm{N}_{2} \mathrm{O}_{5}$ & $\infty^{n}$ & & \\
\hline (H15) & $\mathrm{NO}_{3}$ & $2.1(5)^{a}$ & $-17.3^{a}$ & $K_{\mathrm{H} 19}$ \\
\hline (H16) & $\mathrm{SO}_{2}$ & $1.2(0)$ & -6.27 & Hoffman and Calvert [1985] \\
\hline$(\mathrm{H} 17)$ & $\mathrm{NH}_{3}$ & $7.4(1)$ & -6.80 & Hales and Drewes [1979] \\
\hline $\begin{array}{l}\text { Reaction } \\
\text { No. }\end{array}$ & Reaction & $\begin{array}{c}K_{\mathrm{H}, 298} \\
M^{2} \mathrm{~atm}^{-1}\end{array}$ & $\begin{array}{c}\Delta \mathrm{H}_{298}{ }^{\circ} \\
\mathrm{kcal}^{-1} \\
\mathrm{~mol}^{-1}\end{array}$ & Reference \\
\hline (HI8) & $\mathrm{HCl}(\mathrm{g})=\mathrm{H}^{+}+\mathrm{Cl}^{-}$ & $2.05(6)$ & -18 & Hoffman and Calvert [1985] \\
\hline$(\mathrm{H} 19)$ & $\mathrm{HNO}_{3}(\mathrm{~g})=\mathrm{H}^{+}+\mathrm{NO}_{3}{ }^{-}$ & $3.3(6)$ & -17.3 & Schwartz and White [1981] \\
\hline \multicolumn{5}{|c|}{$\begin{array}{l}\text { Read } 1.10(-2) \text { as } 1.10 \times 10^{-2} \text {. } \\
{ }^{a} \text { Estimated value. } \\
{ }^{b} \text { Assumed to be the same as for } \mathrm{H}_{2} \mathrm{O} \text { [Latimer, 1952]. } \\
{ }^{c} \text { The relation } K_{\mathrm{H} 5}=K_{\mathrm{H}_{6} \mathrm{O}}\left(K_{\mathrm{H3}} / K_{\mathrm{H} 4}\right) \text { is assumed. } \\
{ }^{d} \text { Equilibrium } \mathrm{CH}_{2} \mathrm{O}(\mathrm{g}) \stackrel{\mathrm{H}_{2} \mathrm{C}}{\leftrightharpoons} \mathrm{H}_{2} \mathrm{C}(\mathrm{OH})_{2} \text {. } \\
{ }^{e} \mathrm{~K}_{\mathrm{H} 9}=5.6 \times 10^{3} \mathrm{M} \text { atm }{ }^{-1} \\
\text { ensitivity calculation (see text). }\end{array}$} \\
\hline
\end{tabular}

The species $\mathrm{HCOOH}(\mathrm{g})$ has been added to the gas-phase chemical mechanism of Logan et al. [1981] because of its importance in cloud. It is produced in the gas phase by addition of $\mathrm{HO}_{2}(\mathrm{~g})$ to $\mathrm{CH}_{2} \mathrm{O}(\mathrm{g})$ [Su et al., 1979; Atkinson and Lloyd, 1984]:

$$
\begin{gathered}
\mathrm{CH}_{2} \mathrm{O}+\mathrm{HO}_{2} \leftrightarrows \mathrm{O}_{2} \mathrm{CH}_{2} \mathrm{OH} \\
K=6.7 \times 10^{-15} \mathrm{~cm}^{3}
\end{gathered}
$$

$$
\begin{gathered}
\mathrm{O}_{2} \mathrm{CH}_{2} \mathrm{OH}+\mathrm{HO}_{2} \rightarrow \mathrm{HCOOH}+\mathrm{H}_{2} \mathrm{O}+\mathrm{O}_{2} \\
k=2 \times 10^{-12} \mathrm{~cm}^{3} \mathrm{~s}^{-1}
\end{gathered}
$$

(RG10)

$$
\mathrm{O}_{2}
$$

$$
\mathrm{O}_{2} \mathrm{CH}_{2} \mathrm{OH}+\mathrm{NO} \stackrel{\mathrm{O}_{2}}{\rightarrow} \mathrm{HCOOH}+\mathrm{NO}_{2}+\mathrm{HO}_{2}
$$

$$
k=7 \times 10^{-12} \mathrm{~cm}^{3} \mathrm{~s}^{-1}
$$

(RG11)

$$
\begin{gathered}
\mathrm{O}_{2} \mathrm{CH}_{2} \mathrm{OH}+\mathrm{O}_{2} \mathrm{CH}_{2} \mathrm{OH} \stackrel{\mathrm{O}_{2}}{\rightarrow} 2 \mathrm{HCOOH}+2 \mathrm{HO}_{2} \\
k=1.2 \times 10^{-13} \mathrm{~cm}^{3} \mathrm{~s}^{-1}
\end{gathered}
$$

and is also a low-yield product of the gas-phase reaction of $\mathrm{C}_{2} \mathrm{H}_{4}$ with $\mathrm{O}_{3}$. The stoichiometry proposed by Chameides [1984] was adopted here:

d CO:

react in-
The gas-phase sink for $\mathrm{HCOOH}(\mathrm{g})$ is reaction with $\mathrm{OH}(\mathrm{g})$ [Zetzsch and Stuhl, 1982]:

(RG13)

$$
\begin{gathered}
\mathrm{HCOOH}+\mathrm{OH} \stackrel{\mathrm{O}_{2}}{\rightarrow} \mathrm{CO}_{2}+\mathrm{HO}_{2}+\mathrm{H}_{2} \mathrm{O} \\
k=3.2 \times 10^{-13} \mathrm{~cm}^{3} \mathrm{~s}^{-1}
\end{gathered}
$$

The species $\mathrm{CH}_{3} \mathrm{OH}(\mathrm{g}), \mathrm{SO}_{2}(\mathrm{~g})$, and $\mathrm{NH}_{3}(\mathrm{~g})$ have also been added to the gas-phase mechanism. These species have fairly long lifetimes (several days) against oxidation by $\mathrm{OH}(\mathrm{g})$, their main gas-phase chemical sink; in a cloud, however, they may be rapidly depleted by gas-droplet transfer. Their concentrations are held at a fixed value under cloud-free conditions, and this constraint is relaxed upon cloud formation to allow them to be scavenged by the cloud droplets.

\section{Aqueous-Phase Chemical Mechanism}

The aqueous-phase chemical mechanism is given in Table 2. The mechanism draws from the earlier work of Graedel and Wechsler [1981], Chameides and Davis [1982], Jacob and Hoffmann [1983]; Graedel and Goldberg [1983], Chameides [1984], and Hoffmann and Calvert [1985]. A number of reactions have been added to the above mechanisms, and rate constants have been updated based on recent literature. Rates and equilibrium constants were estimated for reactions for which no data are available. Reactions that are too slow to affect the chemistry over the lifetime of a cloud were generally excluded from Table $2 c$, although a few of these reactions are listed to stress that the reaction in question is indeed slow. These slow reactions are indicated by footnote $d$ (Table $2 c$.) The reactions of 
TABLE $2 b$. Aqueous-Phase Chemistry: Aqueous-Phase Equilibrium Constants

\begin{tabular}{|c|c|c|c|c|}
\hline $\begin{array}{c}\text { Reaction } \\
\text { No. }\end{array}$ & Reaction & $\begin{array}{c}K_{298} \\
M^{n}\end{array}$ & $\begin{array}{c}\Delta \mathrm{H}_{298^{\circ}}{ }^{\circ}, \\
\mathrm{kcal} \\
\mathrm{mol}^{-1}\end{array}$ & Reference \\
\hline (RA1) & $\mathrm{H}_{2} \mathrm{O}=\mathrm{H}^{+}+\mathrm{OH}^{-}$ & $1.00(-14)$ & 13.34 & Hoffmann and Calvert [1985] \\
\hline (RA2) & $\mathrm{HO}_{2}=\mathrm{H}^{+}+\mathrm{O}_{2}^{-}$ & $2.05(-5)$ & 0. & Bielski [1978] \\
\hline (RA3) & $\mathrm{H}_{2} \mathrm{O}_{2}=\mathrm{H}^{+}+\mathrm{HO}_{2}^{-}$ & $1.58(-12)$ & 7.4 & Hoffmann and Calvert [1985] \\
\hline (RA4) & $\mathrm{HCOOH}=\mathrm{H}^{+}+\mathrm{HCOO}^{-}$ & $1.78(-4)$ & 0.3 & Sillen and Martell [1964] \\
\hline (RA5) & $\mathrm{HNO}_{2}=\mathrm{H}^{+}+\mathrm{NO}_{2}^{-}$ & $5.1(-4)$ & 2.5 & Schwartz and White [1981] \\
\hline (RA6) & $\mathrm{H}_{2} \mathrm{CO}_{3}=\mathrm{H}^{+}+\mathrm{HCO}_{3}^{-}$ & $4.4(-7)$ & 2.0 & Hoffmann and Calvert [1985] \\
\hline (RA7) & $\mathrm{SO}_{2} \cdot \mathrm{H}_{2} \mathrm{O}=\mathrm{H}^{+}+\mathrm{HSO}_{3}-$ & $1.3(-2)$ & -4.0 & Hoffmann and Calvert [1985] \\
\hline (RA8) & $\mathrm{HSO}_{3}{ }^{-}=\mathrm{H}^{+}+\mathrm{SO}_{3}{ }^{2-}$ & $6.31(-8)$ & -2.99 & Hoffmann and Calvert [1985] \\
\hline (RA9) & $\mathrm{NH}_{3} \cdot \mathrm{H}_{2} \mathrm{O}=\mathrm{NH}_{4}^{+}+\mathrm{OH}^{-}$ & $1.7(-5)$ & 0.9 & Hoffmann and Calvert [1985] \\
\hline (RA10) & $\mathrm{CH}_{2} \mathrm{O} \stackrel{\mathrm{H}_{2} \mathrm{O}}{=} \mathrm{H}_{2} \mathrm{C}(\mathrm{OH})_{2}$ & $1.8(3)$ & -8.04 & Bell $[1966]$ \\
\hline (RA11) & $\mathrm{Cl}^{-}+\overrightarrow{\mathrm{Cl}}=\mathrm{Cl}_{2}-$ & $1.9(5)$ & $0 .{ }^{b}$ & Jayson et al. [1973] \\
\hline (RA12) & $\mathrm{HOCH}_{2} \mathrm{SO}_{3}^{-}=-\mathrm{OCH}_{2} \mathrm{SO}_{3}^{-}+\mathrm{H}^{+}$ & $2.0(-12)$ & $0 . .^{b}$ & Sorensen and Andersen $[1970]$ \\
\hline
\end{tabular}

Read $1.00(-14)$ as $1.00 \times 10^{-14}$.

${ }^{a}$ Baxendale et al. [1971].

${ }^{b}$ Estimated value.

$\mathrm{CO}_{3}{ }^{-}, \mathrm{Cl}_{2}{ }^{-}$, and aqueous-phase odd $\mathrm{N}$ species were included in the calculations for consistency with previous models but were found to play a negligible role in the droplet chemistry of interest here. They will not be discussed further.

Very few data are available for the activation energies $E_{a}$ of aqueous-phase radical reactions. When no data were available, $E_{a}$ was estimated from the rate constant $k$ at $298 \mathrm{~K}$ and a typical value $A=1 . \times 10^{10} M^{-1} \mathrm{~s}^{-1}$ for the preexponential factor in the Arrhenius epression. A lower limit to the apparent activation energy of an aqueous-phase bimolecular reaction is the temperature dependence of the diffusion-controlled reaction, which corresponds to $E_{a} \approx 3 \mathrm{kcal} \mathrm{mol}^{-1}$ in an Arrhenius formulation [Glasstone et al., 1941]. If $A=1 \times 10^{10}$ $M^{-1} \mathrm{~s}^{-1}$ were assumed for reactions with $k>7 \times 10^{7} M^{-1}$ $\mathrm{s}^{-1}$, activation energies below this lower limit would be predicted; instead, $E_{a}=3 \mathrm{kcal} \mathrm{mol}^{-1}$ was assumed for all reactions with $k>7 \times 10^{7} M^{-1} \mathrm{~s}^{-1}$. Estimates of $E_{a}$ by the above method are consistent with experimental data for the two aqueous-phase radical reactions in Table $2 c$ for which data are available: $E_{a}=4.7 \mathrm{kcal} \mathrm{mol}^{-1}$ and $\log A=9.8$ for $\mathrm{HO}_{2}$ $+\mathrm{HO}_{2}$ [Thomas and Ingold, 1968], and $E_{a}=3.4 \mathrm{kcal} \mathrm{mol}^{-1}$ and $\log A=9.9$ for $\mathrm{OH}+\mathrm{H}_{2} \mathrm{O}_{2}$ [Christensen et al., 1982].

The focus of discussion in this paper is the chemistry of a mature cloud, 1 hour after cloud formation. The assumption that the newly formed cloud droplets reach a stable $10-\mu \mathrm{m}$ radius "instantaneously" must be discussed from this standpoint. The time required for activated nuclei to reach such a size under typical supersaturated conditions is of the order of a minute [Pruppacher and Klett, 1978]. Scavenging of soluble gases by the cloud droplets proceeds on a similar time scale [Levine and Schwartz, 1982; Jacob, 1985]. During the first few minutes of cloud formation, soluble gases are progressively depleted from the gas phase by the growing droplets; the rates of these transient processes cannot be simulated accurately by the model because no attempt is made to simulate droplet growth. However, the net result, that soluble gases are depleted during the first few minutes of cloud formation, is predicted properly. For the present purpose a precise determination of the actual rates at which transient chemical processes occur in the initially growing cloud is of no real importance. Past this initial period, changes in the chemical composition of the cloud proceed at a much slower pace.

Cloud water $p \mathrm{H}$ stabilizes within minutes following cloud formation and subsequently changes very little over the lifetime of the cloud. The main chemical processes controlling the $p \mathrm{H}$ are (1) the dissolution of condensation nuclei, (2) the scavenging of acidic and alkaline gases initially present in the air $\left(\mathrm{HNO}_{3}, \mathrm{SO}_{2}, \mathrm{HCl}, \mathrm{HCOOH}, \mathrm{CO}_{2}, \mathrm{NH}_{3}\right.$ ), and (3) the oxidation of S(IV). All of these processes take place on a time scale of minutes [Chameides, 1984; Jacob, 1985]. Production of $\mathrm{HCOOH}$ in the aqueous phase proceeds over a longer time scale but is too small to have a significant effect on $p \mathrm{H}$. When condensation takes place on neutral nuclei, as in the standard simulation, the cloud water $p \mathrm{H}$ is given to a good approximation by a balance of the major acidic $\left(\mathrm{HNO}_{3}, \mathrm{SO}_{2}, \mathrm{HCl}\right.$, $\left.\mathrm{HCOOH}, \mathrm{CO}_{2}\right)$ and alkaline $\left(\mathrm{NH}_{3}\right)$ species present in the atmosphere before cloud formation (Table $1 b$ ). If quantitative oxidation of $\mathrm{SO}_{2}$ to $\mathrm{H}_{2} \mathrm{SO}_{4}$ is assumed [Chameides, 1984], the $p \mathrm{H}$ can be calculated readily. With the conditions of Table 1 , one finds $p \mathrm{H}=4.16$.

This rather low $p \mathrm{H}$ value is due mostly to the scavenging of acidic gases, whose concentrations in the remote troposphere may vary considerably from the values given in Table $1 b$. The cloud water $p \mathrm{H}$ is also very sensitive to the acidity of the condensation nuclei. Therefore it is necessary to study the sensitivity of the calculations to the cloud water $p \mathrm{H}$ imposed by the initial conditions. A series of simulations were conducted where $\mathrm{H}^{+}$or $\mathrm{OH}^{-}$were added to the neutral nuclei in various quantities to give cloud water $p H$ values ranging from 3 to 7 . This method for specifying the initial atmospheric acidity is somewhat artificial because it ignores the thermodynamic partitioning of the acidity between the gas phase and the aerosol phases [cf. Jacob et al., 1986a, b]. However, modifying the acidity of the nuclei is for the present purpose equivalent to modifying the initial concentrations of acidic or alkaline gases, because these gases are rapidly scavenged upon cloud formation.

\section{Gas-Droplet Transfer}

Consider a gas-phase species $i$ present in the cloud with concentration $n_{i}$ (measured in molecules per cubic centimeter of air) and dissolving in the cloud droplets to give aqueousphase species $j$ with concentration $C_{j}(M)$. Mass transport in clouds is controlled by molecular diffusion [Schwartz, 1986]. The absorption flux $\Phi_{\text {in }}$ (in molecules per cubic centimeter of air per second) of species $i$ to the cloud droplets is given by 
TABLE 2c. Aqueous-Phase Chemistry: Aqueous-Phase Reaction Rate Constants

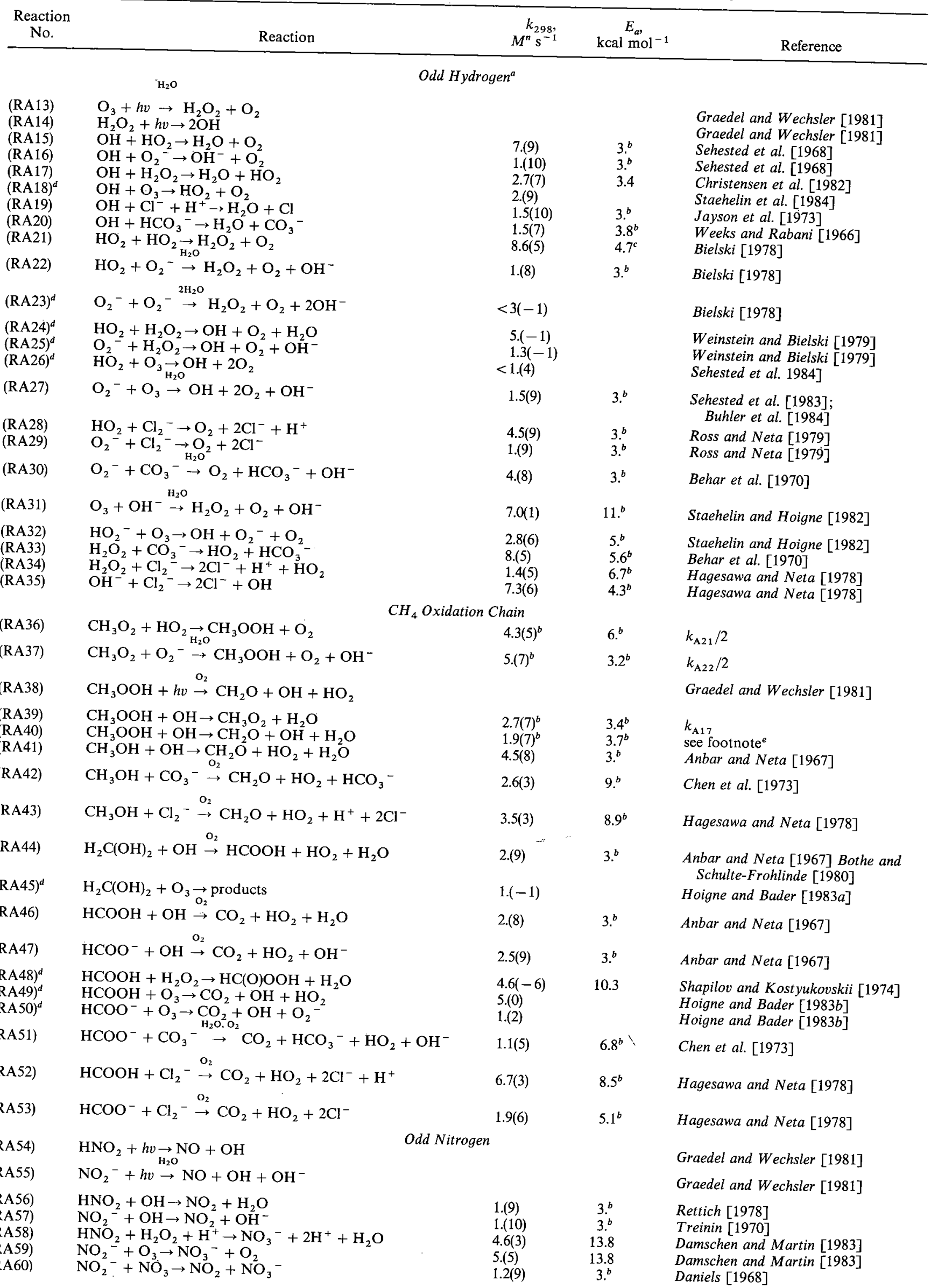

ze life-

ng the

a scav-

the air

oxida-

e scale

ion of

ir time

When

indard

sproxi-

$\mathrm{HCl}$,

the at-

titative

4], the

able 1 ,

ging of isphere

$b$. The

of the

dy the

nposed

induct-

sclei in

ig from

ic acid.

lynam-

ind the

difying

iivalent

llkaline

1 cloud

Id with timeter jueousport in 1986]. zeter of . by
$\mathrm{O}_{3}+h v \rightarrow \mathrm{H}_{2} \mathrm{O}_{2}+\mathrm{O}_{2}$

$+h v \rightarrow 2 \mathrm{OH}$

$\mathrm{OH}+\mathrm{O}_{2} \rightarrow \mathrm{OH}^{-}+\mathrm{O}_{2}$

$\mathrm{OH}+\mathrm{H}_{2} \mathrm{O}_{2} \rightarrow \mathrm{H}_{2} \mathrm{O}+\mathrm{HO}_{2}$

$\rightarrow \mathrm{HO}_{2}+\mathrm{O}_{2}$

$\mathrm{HO}_{2}+\mathrm{HO}_{2} \rightarrow \mathrm{H}_{2} \mathrm{O}_{2}+\mathrm{O}_{2}$

$\mathrm{HO}_{2}+\mathrm{O}_{2}^{-} \rightarrow \mathrm{H}_{2} \mathrm{O}_{2}+\mathrm{O}_{2}+\mathrm{OH}^{-}$

$\mathrm{O}_{2}^{-}+\mathrm{O}_{2}^{-} \rightarrow \mathrm{H}_{2} \mathrm{O}_{2}+\mathrm{O}_{2}+2 \mathrm{OH}^{-}$

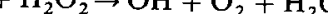

$\mathrm{HO}_{2}+\mathrm{O}_{3} \underset{\mathrm{H}_{2} \mathrm{O}}{\rightarrow} \mathrm{OH}+2 \mathrm{O}_{2}$

$1.3(-1)$

$1 .(4)$

$4.5(9)$

$\mathrm{O}_{2}{ }^{-}+\mathrm{Cl}_{2}{ }^{-} \rightarrow \mathrm{O}_{2} \mathrm{O}^{2}+2 \mathrm{Cl}^{-}$

$\mathrm{O}_{3}+\mathrm{OH}^{-} \stackrel{\mathrm{H}_{2} \mathrm{O}}{\rightarrow} \mathrm{H}_{2} \mathrm{O}_{2}+\mathrm{O}_{2}+\mathrm{OH}^{-}$

$+\mathrm{O}_{3} \rightarrow \mathrm{OH}+\mathrm{O}_{2}^{-}+\mathrm{O}_{2}$

$\mathrm{H}_{2} \mathrm{O}_{2}+\mathrm{Cl}_{2}{ }^{-} \rightarrow 2 \mathrm{Cl}^{-}+\mathrm{H}^{+}+\mathrm{HO}_{2}$

$\mathrm{CH}_{3} \mathrm{O}_{2}+\mathrm{HO}_{2} \rightarrow \mathrm{CH}_{3} \mathrm{OOH}+\mathrm{O}_{2}$

$\mathrm{CH}_{3} \mathrm{O}_{2}+\mathrm{O}_{2}^{-} \rightarrow \mathrm{CH}_{3} \mathrm{OOH}+\mathrm{O}_{2}+\mathrm{OH}^{-}$

$\mathrm{CH}_{3} \mathrm{OOH}+h v \rightarrow \mathrm{CH}_{2} \mathrm{O}+\mathrm{OH}+\mathrm{HO}_{2}$

$\mathrm{CH}_{3} \mathrm{OH}+\mathrm{OH} \rightarrow \mathrm{CH}_{2} \mathrm{O}+\mathrm{HO}_{2}+\mathrm{H}_{2} \mathrm{O}$

$\mathrm{CH}_{3} \mathrm{OH}+\mathrm{CO}_{3}{ }^{-} \rightarrow \mathrm{CH}_{2} \mathrm{O}+\mathrm{HO}_{2}+\mathrm{HCO}_{3}{ }^{-}$

$\rightarrow \mathrm{CH}_{2} \mathrm{O}+\mathrm{HO}_{2}+\mathrm{H}^{+}+2 \mathrm{Cl}^{-}$

$\left(\frac{10}{20}\right.$

1. $(-1)$

\section{(RA46)}

\section{(RA47)}

(RA50)

(RA51)

(RA52)

(RA53)

(RA54)

$\mathrm{HNO}_{2}+h v \rightarrow \mathrm{NO}+\mathrm{OH}$

$1.2(9)$
Graedel and Wechsler [1981]

Gredel and Wechsler [1981]

Sehested et al [1968]

Christensen et al. [1982]

Bielski [1978]

Weinstein and Bielski [1979]

Weinstein and Bielski [1979]

hested et al. 1984]

Ross and Neta [1979]

Ross and Neta [1979]

Behar et al. [1970]

Hagesawa and Neta [1978]

$k_{A 21} / 2$

A22/2

see footnote

Anbar and Neta [1967]

al. [1973]

nbar and Neta [1967] Bothe and Schulte-Frohlinde [1980]

Shapilov and Kostyukovskii [1974]

Hoigne and Bader [1983b]

Daniels [1968] 
TABLE $2 c . \quad$ (continued)

\begin{tabular}{|c|c|c|c|c|}
\hline $\begin{array}{l}\text { Reaction } \\
\text { No. }\end{array}$ & Reaction & $\begin{array}{l}k_{298} \\
M^{n} \mathrm{~s}^{-1}\end{array}$ & $\begin{array}{c}E_{a} \\
\mathrm{kcal}^{\mathrm{mol}^{-1}}\end{array}$ & Reference \\
\hline \multicolumn{5}{|c|}{ Odd Nitrogen (continued) } \\
\hline $\begin{array}{l}(\text { RA61) } \\
(\text { RA62) }\end{array}$ & $\begin{array}{l}\mathrm{NO}_{2}^{-}+\mathrm{Cl}_{2}^{-} \rightarrow \mathrm{NO}_{2}+2 \mathrm{Cl}^{-} \\
\mathrm{NO}_{2}+\underset{\mathrm{H}_{2} \mathrm{O}}{\mathrm{OH}} \rightarrow \mathrm{NO}_{3}^{-}+\mathrm{H}^{+}\end{array}$ & $\begin{array}{l}2.5(8) \\
1.3(9)\end{array}$ & $3 .^{b}$ & $\begin{array}{l}\text { Hagesawa and Neta }[1978] \\
\text { Gratzel et al. }[1970]\end{array}$ \\
\hline (RA63) & $2 \mathrm{NO}_{2} \underset{\mathrm{H}_{2} \mathrm{O}}{\rightarrow} \mathrm{HNO}_{2}+\mathrm{H}^{+}+\mathrm{NO}_{3}^{-}$ & 1.(8) & 3. ${ }^{b}$ & Lee and Schwartz [1981] \\
\hline (RA64) & $\mathrm{NO}_{2}+\mathrm{NO} \underset{\mathrm{H}_{2} \mathrm{O}}{\stackrel{\mathrm{H}_{2} \mathrm{O}}{\rightarrow}} 2 \mathrm{H}^{+}+2 \mathrm{NO}_{2}^{-}$ & 3.(8) & 3. ${ }^{b}$ & Hoffmann and Calvert [1985] \\
\hline (RA65) & $\mathrm{NO}_{3}{ }^{-}+h v \rightarrow \mathrm{NO}_{2}+\mathrm{OH}+\mathrm{OH}^{-}$ & & & Graedel and Wechsler [1981] \\
\hline $\begin{array}{l}\text { (RA66) } \\
\text { (RA67) } \\
\text { (RA68) } \\
\text { (RA69) } \\
\text { (RA70) }\end{array}$ & $\begin{array}{l}\mathrm{NO}_{3}+h v \rightarrow \mathrm{NO}+\mathrm{O}_{2} \\
\mathrm{NO}_{3}+\mathrm{HO}_{2} \rightarrow \mathrm{NO}_{3}^{-}+\mathrm{H}^{+}+\mathrm{O}_{2} \\
\mathrm{NO}_{3}+\mathrm{O}_{2}^{-} \rightarrow \mathrm{NO}_{3}^{-}+\mathrm{O}_{2} \\
\mathrm{NO}_{3}+\mathrm{H}_{2} \mathrm{O}_{2} \rightarrow \mathrm{NO}_{3}^{-}+\mathrm{H}^{+}+\mathrm{HO}_{2} \\
\mathrm{NO}_{3}+\mathrm{Cl}^{-} \rightarrow \mathrm{NO}_{3}^{-}+\mathrm{Cl}\end{array}$ & $\begin{array}{l}4.5(9)^{b} \\
1 .(9)^{b} \\
1 .(6) \\
1 .(8)\end{array}$ & $\begin{array}{l}3 .{ }^{b} \\
3 .^{b} \\
5.5^{b} \\
3 .^{b}\end{array}$ & $\begin{array}{l}\text { Graedel and Wechsler }[1981] \\
k_{\mathrm{A} 28} \\
k_{\mathrm{A} 29} \\
\text { Chameides }[1984] \\
\text { Ross and Neta }[1979]\end{array}$ \\
\hline (RA71) & $\mathrm{NO}_{3}+\mathrm{CH}_{3} \mathrm{OH} \underset{\mathrm{O}_{2}}{\stackrel{\mathrm{O}_{2}}{\rightarrow}} \mathrm{NO}_{3}^{-}+\mathrm{H}^{+}+\mathrm{CH}_{2} \mathrm{O}+\mathrm{HO}_{2}$ & $1 .(6)^{b}$ & $5.5^{b}$ & Dogliotti and Hayon [1967] \\
\hline (RA72) & $\mathrm{NO}_{3}+\mathrm{HCOOH} \stackrel{\mathrm{O}_{2}}{\rightarrow} \mathrm{NO}_{3}^{-}+\mathrm{H}^{+}+\mathrm{CO}_{2}+\mathrm{HO}_{2}$ & $2.1(5)$ & $6.4^{b}$ & Dogliotti and Hayon [1967] \\
\hline & $\begin{array}{r}\mathrm{NO}_{3}+\mathrm{HCOO}^{-} \stackrel{\mathrm{O}_{2}}{\rightarrow} \mathrm{NO}_{3}^{-}+\mathrm{CO}_{2}+\underset{S(I V) \text { Complexati }}{\mathrm{HO}_{2}} \\
\text { S }\end{array}$ & $\begin{array}{l}6 .(7)^{b} \\
\text { nd Oxidation }\end{array}$ & $3 .^{b}$ & see footnote ${ }^{S}$ \\
\hline $\begin{array}{l}\text { (RA74) } \\
\text { (RA75) } \\
\text { (RA76) } \\
\text { (RA77) } \\
\text { (RA78) } \\
\text { (RA79) } \\
\text { (RA80) } \\
\text { (RA81a) } \\
\text { (RA81b) }^{h} \\
\text { (RA81c) }^{h}\end{array}$ & 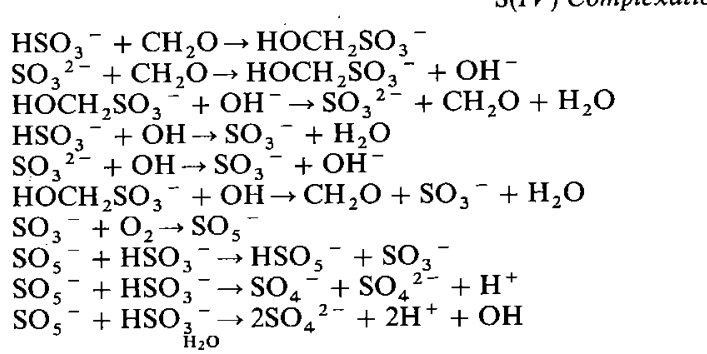 & $\begin{array}{l}7.9(2) \\
2.5(7) \\
3.6(3) \\
9.5(9) \\
5.5(9) \\
1.4(9)^{b} \\
1.5(9) \\
3 .(6)\end{array}$ & $\begin{array}{l}9.7^{b} \\
3.6^{b} \\
9 .{ }^{b} \\
3 .{ }^{b} \\
3 .{ }^{b} \\
3 .{ }^{b} \\
3 .{ }^{b} \\
4.8^{b}\end{array}$ & $\begin{array}{l}\text { Boyce and Hoffmann }[1984] \\
\text { Boyce and Hoffmann }[1984] \\
\text { Munger et al. }[1986] \\
\text { Adams and Boag }[1964] \\
\text { Adams and Boag }[1964] \\
\text { see footnote } \\
\text { Huie and Neta }[1984] \\
\text { Huie and Neta }[1984]^{j}\end{array}$ \\
\hline (RA82) & $\mathrm{SO}_{5}^{-}+\mathrm{O}_{2}^{-} \underset{\mathrm{O}_{2}}{-} \underset{\mathrm{HSO}_{5}}{-}+\mathrm{OH}^{-}+\mathrm{O}_{2}$ & 1. $(8)^{b}$ & $3 .^{b}$ & $k_{\mathrm{A} 22}$ \\
\hline (RA83) & $\mathrm{SO}_{5}{ }^{-}+\mathrm{HCOOH} \underset{\mathrm{O}_{2}}{\rightarrow} \mathrm{HSO}_{5}{ }^{-}+\mathrm{CO}_{2}+\mathrm{HO}_{2}$ & 2.(2) & $10.6^{b}$ & see footnote ${ }^{i}$ \\
\hline (RA84) & $\mathrm{SO}_{5}^{-}+\mathrm{HCOO}^{-} \stackrel{\mathrm{O}_{2}}{\rightarrow} \mathrm{HSO}_{5}^{-}+\mathrm{CO}_{2}+\mathrm{O}_{2}^{-}$ & $1.4(4)^{b}$ & $8 .^{b}$ & see footnote ${ }^{i}$ \\
\hline $\begin{array}{l}\text { (RA85) } \\
\text { (RA86) }^{(R A 87)} \\
\text { (RA88) }^{d} \\
\text { (RA89) }^{d} \\
\text { (RA90) }^{d} \\
\text { (RA91) }^{\text {(RA92) }} \\
\text { (RA93) } \\
\text { (RA94) }^{\text {(RA95) }} \\
\text { (RA96) } \\
\text { (RA97) }\end{array}$ & 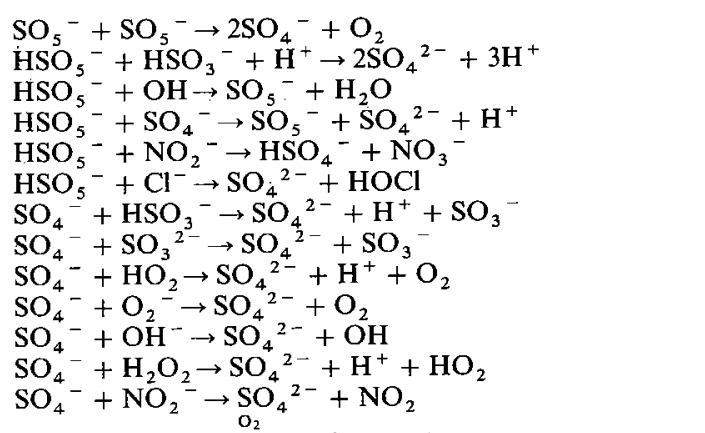 & $\begin{array}{l}2 .(8)^{b} \\
7.5(7)^{b} \\
1.7(7) \\
<1 .(5) \\
3.1(-1) \\
1.8(-3) \\
1.3(9) \\
5.3(8) \\
5 .(9)^{b} \\
5 .(9)^{b} \\
8 .(7) \\
1.2(7) \\
8.8(8)\end{array}$ & $\begin{array}{l}3 .^{b} \\
9.45^{b} \\
3.8^{b} \\
13.2 \\
14.0 \\
3 .{ }^{b} \\
3 .^{b} \\
3 .^{b} \\
3 .^{b} \\
3 .^{b} \\
4 .^{b} \\
3 .^{b}\end{array}$ & $\begin{array}{l}\text { see footnote }{ }^{j} \\
k_{\mathrm{A} 107}{ }^{j} \\
\text { Maruthamuthu and Neta }[1977] \\
\text { Maruthamuthu and Neta }[1977] \\
\text { Edwards and Mueller }[1962] \\
\text { Fortnum et al. }[1960] \\
\text { Hayon et al. }[1972] \\
\text { Hayon et al. }[1972] \\
\text { see footnote }{ }^{l} \\
\text { see footnote } \\
\text { Maruthamuthu and Neta }[1978] \\
\text { Maruthamuthu and Neta }[1978] \\
\text { Maruthamuthu and Neta }[1978]\end{array}$ \\
\hline (RA98) & $\mathrm{SO}_{4}^{-}+\mathrm{CH}_{3} \mathrm{OH} \stackrel{\mathrm{O}_{2}}{\rightarrow} \mathrm{SO}_{4}{ }^{2-}+\mathrm{H}^{+}+\mathrm{CH}_{2} \mathrm{O}+\mathrm{HO}_{2}$ & $2.5(7)$ & $3.6^{b}$ & Dogliotti and Hayon [1967] \\
\hline (RA99) & 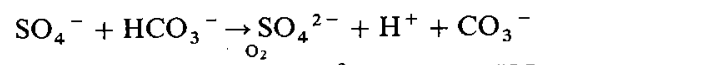 & $9.1(6)$ & $4.2^{b}$ & Dogliotti and Hayon [1967] \\
\hline (RA100) & $\mathrm{SO}_{4}{ }^{-}+\mathrm{HCOO}^{-} \rightarrow \mathrm{SO}_{4}{ }^{2-}+\mathrm{CO}_{2}+\mathrm{HO}_{2}$ & $1.7(8)^{b}$ & $3 .^{b}$ & Ross and Neta [1979] \\
\hline (RA101) & $\mathrm{SO}_{4}^{-}+\mathrm{Cl}^{-} \rightarrow \mathrm{SO}_{4}{ }^{2-}+\mathrm{Cl}$ & 2.(8) & $3 .^{b}$ & Ross and Neta [1979] \\
\hline (RA102) & $\mathrm{SO}_{4}^{-}+\mathrm{HCOOH} \stackrel{\mathrm{O}_{2}}{\rightarrow} \mathrm{SO}_{4}^{2-}+\mathrm{H}^{+}+\mathrm{CO}_{2}+\mathrm{HO}_{2}$ & $1.4(6)$ & $5.3^{\circ}$ & Ross and Neta [1979] \\
\hline $\begin{array}{l}\text { (RA103) } \\
\text { (RA104) } \\
\text { (RA105) } \\
\text { (RA106) } \\
\text { (RA107) } \\
\text { (RA108) }\end{array}$ & $\begin{array}{l}\mathrm{HSO}_{3}{ }^{-}+\mathrm{Cl}_{2}{ }^{-} \rightarrow \mathrm{SO}_{3}{ }^{-}+\mathrm{H}^{+}+2 \mathrm{Cl}^{-} \\
\mathrm{SO}_{3}{ }^{2-}+\mathrm{Cl}_{2}-\rightarrow \mathrm{SO}_{3}{ }^{-}+2 \mathrm{Cl}^{-} \\
\mathrm{HSO}_{3}{ }^{-}+\mathrm{O}_{3} \rightarrow \mathrm{SO}_{4}{ }^{2-}+\mathrm{H}^{+}+\mathrm{O}_{2} \\
\mathrm{SO}_{3}{ }^{2-}+\mathrm{O}_{3} \rightarrow \mathrm{SO}_{4}{ }^{2-}+\mathrm{O}_{2} \\
\mathrm{HSO}_{3}{ }^{-}+\mathrm{H}_{2} \mathrm{O}_{2}+\mathrm{H}^{+} \rightarrow \mathrm{SO}_{4}{ }^{2-}+2 \mathrm{H}^{+}+\mathrm{H}_{2} \mathrm{O} \\
\mathrm{HSO}_{3}{ }^{-}+\mathrm{CH}_{3} \mathrm{O}_{7} \mathrm{H}^{+} \mathrm{H}^{+} \rightarrow \mathrm{SO}_{4}{ }^{2-}+\mathrm{CH}_{3} \mathrm{OH}+2 \mathrm{H}^{+}\end{array}$ & $\begin{array}{l}4.6(7) \\
2.3(7) \\
3.2(5) \\
1 .(9) \\
7.45(7) \\
1.91(7)\end{array}$ & $\begin{array}{l}3.2^{b} \\
3.6^{b} \\
9.6 \\
8 . \\
9.45 \\
7.56\end{array}$ & $\begin{array}{l}\text { see footnote }{ }^{m} \\
\text { see footnote } \\
\text { Hoffmann and Calvert }[1985] \\
\text { Hoffmann and Calvert }[1985] \\
\text { Hoffmann and Calvert }[1985] \\
\text { J. A. Lind et al. (unpublished } \\
\quad \text { manuscript, 1986) }\end{array}$ \\
\hline
\end{tabular}

Rate constants are given at $298 \mathrm{~K}$. Read 7.(9) as 7. $\times 10^{9}$. Many reaction expressions in this table represent the sum of successive elementary reaction steps. The rate of the overall reaction is first-order in each of the species on the left-hand side of the reaction equation, to the exclusion of other species. Species above the reaction sign are reactants which do not enter into the rate expression, generally because they are involved in a non-rate-limiting step of the overall reaction. 


$$
\Phi_{\mathrm{in}}=\frac{3 \eta L D_{g, i}}{a^{2}}\left\langle n_{i}\right\rangle
$$

and the volatilization flux $\Phi_{\text {out }}$ (in molecules per cubic centimeter of air per second) of species $j$ to the gas phase is given by

$$
\Phi_{\text {out }}=\frac{3 \eta L D_{g, i}}{a^{2}} \frac{6.023 \times 10^{20} C_{j}{ }^{*}}{K_{\mathrm{H}} R T}
$$

where $a$ is the droplet radius, $L$ is the liquid water content ( $\mathrm{vol} / \mathrm{vol}), D_{g, i}$ is the diffusion coefficient of species $i$ in air, $\left\langle n_{i}\right\rangle$ is the bulk gas-phase concentration (in molecules per cubic centimeter of air) far from the droplet surface, $C_{j}{ }^{*}$ is the aqueous-phase concentration $(M)$ at the droplet surface, $K_{\mathrm{H}}$ is the Henry's law constant ( $M$ per atmosphere), $R=8.314$ $\times 10^{-2} \mathrm{~atm} 1 \mathrm{~mol}^{-1} \mathrm{~K}^{-1}$ is the gas constant, $T$ is the temperature, and $\eta$ is a coefficient correcting for free molecular effects $(0<\eta<1)$. The approximate expression for $\eta$ proposed by Fuchs and Sutugin [1971] was adopted here:

$$
\eta=\left\{1+\left[\frac{1.33+0.71 K n^{-1}}{1+K n^{-1}}+\frac{4(1-\alpha)}{3 \alpha}\right] K n\right\}^{-1}
$$

The Knudsen number $K n$ is the ratio of the mean free path of air to the droplet radius; the sticking coefficient $\alpha$ represents the probability that a gas molecule impinging on the droplet surface will stick to that surface. Figure 1 shows the dependence of $\eta$ on $\alpha$, for a range of cloud droplet radii.

The sticking coefficient is a poorly known quantity, which appears to be quite specific to the nature of the impinging gas and the composition of the surface [Chameides and Davis, 1982]. If the droplet surface were coated by a film of organic surfactants, the surface resistance to gas-droplet transfer could be considerable [Gill et al., 1983]. In the remote troposphere, however, the presence of such a film is unlikely because of the paucity of organic material; one would expect sticking coefficients larger than $10^{-4}$, based on the sparse data available for the impingement of soluble gases on liquid water surfaces [Schwartz, 1986]. Further, one would expect $\alpha$ to increase with the solubility of the gas. An accurate estimate of $\alpha$ is important only for very soluble gases, which may take a long time to equilibrate between the gas phase and the aqueous phase; weakly soluble gases equilibrate on time scales of seconds or less, even if $\alpha$ is small [Chameides, 1984, 1985; Jacob, 1985]. Preliminary data from Aerodyne Research, Inc., and Boston College (M. A. Zahniser and P. Davidovits, personal communication, 1986) indicate that the sticking coefficients of very soluble gases on clean water surfaces range between 0.01 and 1. A value $\alpha=0.1$ was chosen for the standard simulation;

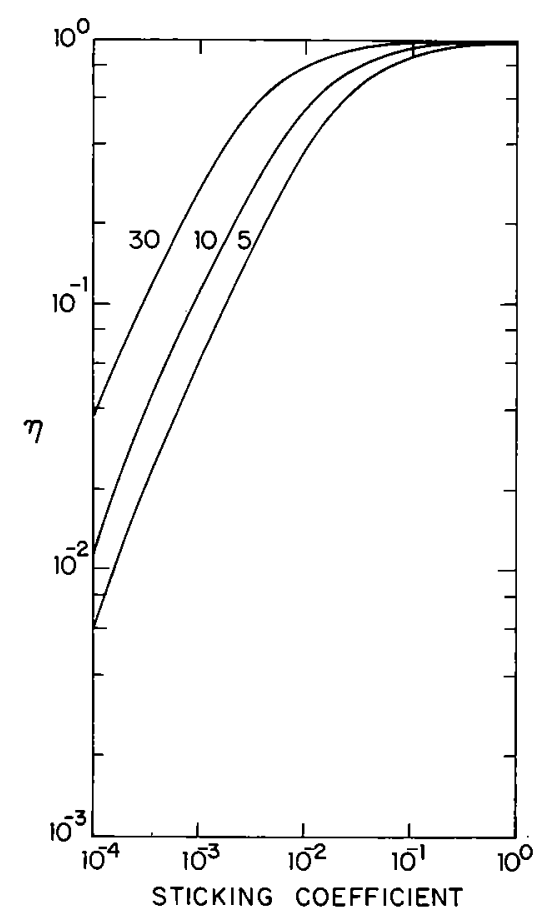

Fig. 1. Free molecular correction $\eta$ to the continuum gas-droplet transfer flux, as a function of sticking coefficient, for droplet radii 5 , 10 , and $30 \mu \mathrm{m}$.

this value has the advantage of giving fairly accurate fluxes as long as $\alpha$ ranges between 0.05 and 1 (Figure 1). Sensitivity calculations will be conducted to evaluate the dependence of the chemistry on $\alpha$.

\section{Mathematical Formulation}

The object of the calculations is to predict the chemical evolution of a well-mixed air parcel containing aqueous droplets. All droplets are assumed to have the same size and the same composition. A system of $m$ chemical species is considered, which includes both gas-phase and aqueous-phase species. Two boundary conditions (Henry's law and flux matching) exist at the surface of the droplets between the concentrations of gas-phase and aqueous-phase species. These boundary conditions do not produce significant gradients in the concentrations of gas-phase species over the scale of the air parcel, because the fraction of the total air volume occupied by cloud droplets is small $\left(10^{-7}-10^{-6}\right)$. Therefore if it

${ }^{a}$ The reaction $\left(\mathrm{HCO}_{3}{ }^{-}+\mathrm{O}_{2}{ }^{-}\right)$s's not included, following the recommendation by Schwartz [1984].

${ }^{b}$ Estimated value.

${ }^{c}$ Thomas and Ingold [1968].

${ }^{d}$ Reaction not in the computational code.

${ }^{e}$ Estimated from (RA39) and the branching ratio of the gas-phase $\left(\mathrm{CH}_{3} \mathrm{OOH}+\mathrm{OH}\right)$ reaction.

${ }^{f}$ The relation $k_{\mathrm{A} 73}=k_{\mathrm{A} 72}\left(k_{\mathrm{A} 53} / k_{\mathrm{A} 52}\right)$ is assumed.

${ }^{\theta}$ Estimated from the rate of reaction $\left(\mathrm{CH}_{3} \mathrm{SO}_{3} \mathrm{H}+\mathrm{OH}\right)$ [Lind and Eriksen, 1975; Saltzman et al., 1983 ].

${ }^{h}$ Branch (RA81 $a$ ) is assumed in the standard simulations; sensitivity calculations are conducted with branches (RA81b) and (RA81c) (see text).

${ }^{i}$ Estimated from the rate of oxidation of ascorbic acid and ascorbate by $\mathrm{SO}_{5}{ }^{-}$[Huie and Neta, 1984], and a ratio of $10^{4}$ between the rate constants for oxidation of formic acid (formate) and ascorbic acid (ascorbate) by $\mathrm{CO}_{3}{ }^{-}$and $\mathrm{Cl}_{2}{ }^{-}\left[\mathrm{Ross}^{2}\right.$ and $\left.\mathrm{Neta}, 1979\right]$.

${ }^{j}$ R. E. Huie, National Bureau of Standards, personal communication, 1985.

${ }^{k}$ See text for discussion.

${ }^{l}$ Assumed to be intermediate between the rates of $\mathrm{O}_{2}(-\mathrm{I})$ oxidation by $\mathrm{OH}$ and $\mathrm{Cl}_{2}{ }^{-}$.

${ }^{m}$ Calculated from the reported rate of $3.3 \times 10^{7} \mathrm{M}^{-1} \mathrm{~s}^{-1}$ for the reaction $\left(\mathrm{Cl}_{2}{ }^{-}+\mathrm{S}(\mathrm{IV})\right)$ at $\mathrm{pH} 7$ [Hagesawa and $\left.\mathrm{Neta}, 1978\right]$, assuming that $\mathrm{HSO}_{3}{ }^{-}$reacts twice as fast as $\mathrm{SO}_{3}{ }^{2-}$ (as in the case of oxidation by $\mathrm{OH}$ ). 
is assumed that the air parcel is well mixed, it may also be assumed that the gas-phase species are well mixed within the air parcel.

Mass transport limitations within the cloud droplets must be examined carefully. The steady state diffusion equation for the concentration $C_{j}(r)(M)$ of aqueous-phase species $j$ is

$$
D_{\mathrm{aq}, j} \frac{1}{r^{2}} \frac{d}{d r}\left(r^{2} \frac{d C_{j}}{d r}\right)-k_{L, j}(r) C_{j}+P_{j}(r)=0
$$

$$
0 \leq r \leq a
$$

where $r$ is the distance from the center of the droplet, $D_{\mathrm{aq}, j}$ is the aqueous-phase molecular diffusion coefficient, $k_{L, j}$ (per second) is the global first-order loss rate constant for species $j$, and $P_{j}(M$ per second) is the global production rate of species $j$ by aqueous-phase reactions. In (4) a family of aqueous-phase species is treated as a single species if the different species in the family are related to one another by equilibria established rapidly relative to the rate of other chemical reactions involving the individual species. For example, the $\mathrm{S}(\mathrm{IV})$ species $\mathrm{SO}_{2} \cdot \mathrm{H}_{2} \mathrm{O}, \mathrm{HSO}_{3}{ }^{-}$, and $\mathrm{SO}_{3}{ }^{2-}$ are treated as a single species [see Schwartz and Freiberg, 1981]. Equation (4) is subject to the boundary conditions:

$$
\begin{gathered}
\left(d C_{j} / d r\right)_{r}=0=0 \\
C_{j}(a)=C_{j}^{*}
\end{gathered}
$$

On the basis of an aqueous-phase diffusion coefficient $D_{\mathrm{aq}, j}=2 \times 10^{-5} \mathrm{~cm}^{2} \mathrm{~s}^{-1}$ (a typical value; [cf. Schwartz, 1986]), the characteristic time for diffusion within a $10-\mu \mathrm{m}$ radius droplet is of order $5 \times 10^{-3} \mathrm{~s}$. Therefore an aqueousphase species is well mixed within a $10-\mu \mathrm{m}$ droplet if its lifetime against chemical removal $\left(k_{L, j}{ }^{-1}\right)$, and its characteristic time for aqueous-phase production $\left(C_{j} / P_{j}\right)$, are both much longer than $5 \times 10^{-3} \mathrm{~s}$. Over the range of model simulations this condition is found to be verified for all species except $\mathrm{O}_{3}(\mathrm{aq}), \mathrm{NO}_{3}(\mathrm{aq}), \mathrm{OH}(\mathrm{aq}), \mathrm{SO}_{4}{ }^{-}, \mathrm{CO}_{3}{ }^{-}$, and $\mathrm{Cl}(\mathrm{aq})+\mathrm{Cl}_{2}{ }^{-}$. Less reactive species are well mixed in the aqueous phase. The treatment of mass transport limitations in the cloud droplet chemistry can then be simplified considerably by noting that chemical reactions between the seven poorly mixed species do not contribute significantly to the chemical evolution of the system. These species are present at concentrations which are very low compared to the concentrations of the well-mixed species with which they react rapidly. Therefore the aqueousphase reactions that need to be considered in the model are at most first order in the concentrations of poorly mixed species; the aqueous-phase reaction rates integrated over the droplet volume can be calculated directly from the bulk concentrations $\left\langle C_{j}\right\rangle$, defined by

$$
\left\langle C_{j}\right\rangle=\left(\frac{4}{3} \pi a^{3}\right)^{-1} \int_{0}^{a} 4 \pi r^{2} C_{j}(r) d r
$$

The surface concentrations of $\mathrm{O}_{3}(\mathrm{aq}), \mathrm{NO}_{3}(\mathrm{aq})$, and $\mathrm{OH}(\mathrm{aq})$ must still be determined in order to calculate the volatilization fluxes of these species. The species $\mathrm{O}_{3}(\mathrm{aq})$ and $\mathrm{NO}_{3}(\mathrm{aq})$ are rapidly removed in the droplets by reactions with well-mixed species $\left(k_{L, j}\right.$ independent of $r$ ), and they are not produced by aqueous-phase sources. The main contributors to $k_{L, j}$ are (RA27) and (RA106) for $\mathrm{O}_{3}(\mathrm{aq})$, and (RA69) and (RA70) for
$\mathrm{NO}_{3}(\mathrm{aq})$. The solution to the aqueous-phase diffusion equation for $\mathrm{O}_{3}(\mathrm{aq})$ and $\mathrm{NO}_{3}(\mathrm{aq})$ is [Schwartz and Freiberg, 1981]

$$
C_{j}(r)=C_{j}{ }^{*} \frac{a}{r} \frac{\sinh \left(q_{j} r / a\right)}{\sinh q_{j}} \quad 0 \leq r \leq a
$$

where

$$
q_{j}=a\left(\frac{k_{L, j}}{D_{\mathrm{aq}, j}}\right)^{1 / 2}
$$

By substituting (8) into (7), one can express the surface concentration $C_{j}{ }^{*}$ as a function of bulk concentrations:

$$
C_{j}^{*}=\left\langle C_{j}\right\rangle\left[3\left(\frac{\operatorname{coth} q_{j}}{q_{j}}-\frac{1}{q_{j}^{2}}\right)\right]^{-1}
$$

The behavior of $\mathrm{OH}(\mathrm{aq})$ is more complicated than that of $\mathrm{O}_{3}(\mathrm{aq})$ or $\mathrm{NO}_{3}(\mathrm{aq})$. $\mathrm{OH}(\mathrm{aq})$ reacts rapidly with a number of well-mixed species (global first-order loss rate constant $k_{L, \mathrm{OH}}$ independent of $r$ ) and is also produced within the aqueous phase. The main aqueous-phase source is the reaction $\mathrm{O}_{2}{ }^{-}+$ $\mathrm{O}_{3}$ (RA27); the rate of $\mathrm{OH}(\mathrm{aq})$ production by this reaction has a radial dependence which follows the radial dependence of the $\mathrm{O}_{3}(\mathrm{aq})$ concentration. The other $\mathrm{OH}(\mathrm{aq})$ sources (mainly (RA14)) involve only well-mixed species, and the corresponding $\mathrm{OH}(\mathrm{aq})$ production rates are independent of $r$. Let $P_{\mathrm{OH}}{ }^{\prime}$ represent the global rate of $\mathrm{OH}(\mathrm{aq})$ production by all aqueous-phase sources except (RA27) $\left(P_{\mathrm{OH}}{ }^{\prime}\right.$ is independent of $r)$ :

$$
P_{\mathrm{OH}}(r)=P_{\mathrm{OH}^{\prime}}+k_{\mathrm{A} 27}\left\langle C_{\mathrm{O}_{2}-}\right\rangle C_{\mathrm{O}_{3}}(r)
$$

The solution to the aqueous-phase diffusion equation for $\mathrm{OH}(\mathrm{aq})$ is

$$
\begin{aligned}
& C_{\mathrm{OH}}(r)=\frac{P_{\mathrm{OH}}{ }^{\prime}}{k_{L, \mathrm{OH}}}+\left(C_{\mathrm{OH}^{*}}{ }^{*}-\frac{P_{\mathrm{OH}}{ }^{\prime}}{k_{L, \mathrm{OH}}}\right) \frac{a}{r} \frac{\sinh \left(q_{\mathrm{OH}} r / a\right)}{\sinh q_{\mathrm{OH}}} \\
& +\frac{k_{\mathrm{A} 27}{ }^{\prime}\left\langle C_{\mathrm{O}_{2}-}\right\rangle C_{\mathrm{O}_{3}}{ }^{*}}{k_{L, \mathrm{OH}}-k_{L, \mathrm{O}_{3}}} \frac{a}{r}\left[\frac{\sinh \left(q_{\mathrm{O}_{3}} r / a\right)}{\sinh q_{\mathrm{O}_{3}}}-\frac{\sinh \left(q_{\mathrm{OH}} r / a\right)}{\sinh q_{\mathrm{OH}}}\right]
\end{aligned}
$$

By substituting (12) into (7), one can express the surface concentration $C_{\mathrm{OH}}^{-a}(a)$ as a function of bulk concentrations :

$$
\begin{aligned}
C_{\mathrm{OH}}{ }^{*}= & \frac{P_{\mathrm{OH}}{ }^{\prime}}{k_{L, \mathrm{OH}}}+\frac{k_{\mathrm{A} 27}\left\langle C_{\mathrm{O}_{2}-}\right\rangle\left\langle C_{\mathrm{O}_{3}}\right\rangle}{k_{L, \mathrm{OH}}-k_{L, \mathrm{O}_{3}}}\left[3\left(\frac{\operatorname{coth} q_{\mathrm{O}_{3}}}{q_{\mathrm{O}_{3}}}-\frac{1}{q_{\mathrm{O}_{3}}{ }^{2}}\right)\right]^{-1} \\
+ & \left(\left\langle C_{\mathrm{OH}}\right\rangle-\frac{P_{\mathrm{OH}}{ }^{\prime}}{k_{L, \mathrm{OH}}}-\frac{k_{\mathrm{A} 27}\left\langle C_{\mathrm{O}_{2}-}\right\rangle\left\langle C_{\mathrm{O}_{3}}\right\rangle}{k_{\mathrm{L}, \mathrm{OH}}-k_{L, \mathrm{O}_{3}}}\right) \\
& \cdot\left[3\left(\frac{\operatorname{coth} q_{\mathrm{OH}}}{q_{\mathrm{OH}}}-\frac{1}{q_{\mathrm{OH}}{ }^{2}}\right)\right]^{-1}
\end{aligned}
$$

Therefore the chemical system can be solved using bulk concentrations for all gas-phase and aqueous-phase species. No distinction is made in the mathematical treatment between these two types of species. Aqueous-phase concentrations and reaction rates are calculated in units of molecules per cubic centimeter of air, in the same way as gas-phase concentrations and reaction rates. Aqueous-phase reaction rate constants are scaled by the liquid water content of the cloud. The concentration $\left\langle n_{j}\right\rangle$ of aqueous-phase species $j$ in molecules per $\mathrm{cm}^{3}$ of air is obtained from $\left\langle C_{j}\right\rangle$ by: 
n equa-

1981]

ce con-

that of nber of it $k_{L, \mathrm{OH}}$ queous $\mathrm{O}_{2}{ }^{-}+$ ion has ence of (mainly sspondet $P_{\mathrm{OH}}{ }^{\prime}$ by all dent of

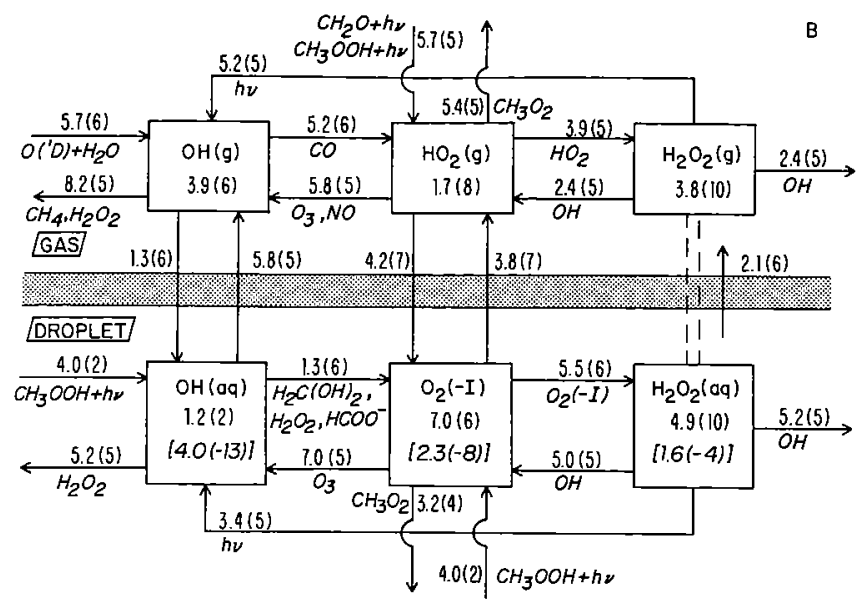

Fig. 2. The odd hydrogen cycle (a) immediately before cloud formation and $(b) 1$ hour after cloud formation. Model conditions are those of Table 1. The main reaction pathways are indicated. Concentrations are in units of molecules per cubic centimeter of air and transformation rates are in units of molecules odd $H$ per cubic centimeter of air per second. Aqueous-phase concentrations $(M)$ are given in brackets. The $\mathrm{H}_{2} \mathrm{O}_{2}(\mathrm{aq})$ volatilization flux is given as the net flux; $\mathrm{H}_{2} \mathrm{O}_{2}(\mathrm{~g})$ and $\mathrm{H}_{2} \mathrm{O}_{2}(\mathrm{aq})$ concentrations are within $1 \%$ of equilibrium by Henry's law.

$$
\left\langle n_{j}\right\rangle=6.023 \times 10^{20} L\left\langle C_{j}\right\rangle
$$

The evolution of the chemical composition of the air parcel is then determined by the system of $m$ equations for gas-phase and aqueous-phase species:

$$
\begin{aligned}
\frac{d\left\langle n_{k}\right\rangle}{d t}=R P_{k}\left(\left\langle n_{1}\right\rangle,\left\langle n_{2}\right\rangle\right. & \left., \cdots,\left\langle n_{m}\right\rangle\right) \\
& -R L_{k}\left(\left\langle n_{1}\right\rangle,\left\langle n_{2}\right\rangle, \cdots,\left\langle n_{m}\right\rangle\right),
\end{aligned}
$$

where $R P_{k}$ and $R L_{k}$ are the total production and loss rates, respectively, of species $k$. These rates include gas-phase or aqueous-phase reaction rates, plus absorption and volatilization at the droplet surface. The reversible aqueous-phase reactions (RA1-RA12) are very fast [Hoffmann, 1981] and are constrained to be at equilibrium at all times in the calculations. The system of (15) is solved by an implicit finite difference method [Richtmeyer, 1957].

\section{The Odd Hydrogen CyCle in Cloud}

The standard simulation considers a cloud forming under the conditions of Table 1. The initial gas-phase composition of the air parcel is determined by iteration of the gas-phase chemical mechanism over successive diurnal cycles until identical noontime concentrations are reproduced from day to day. Figure $2 a$ shows the gas-phase odd $\mathbf{H}$ cycle immediately before cloud formation, and Figure $2 b$ shows the gas-phase and aqueous-phase odd $\mathrm{H}$ cycles one hour after cloud formation. Because $\mathrm{OH}$ has a very short lifetime and is involved in a large number of reactions, its chemistry is more complicated than that of the two other odd hydrogen species, $\mathrm{H}_{2} \mathrm{O}_{2}$ and $\mathrm{HO}_{2}$. Therefore I will first discuss the in-cloud chemistry of $\mathrm{H}_{2} \mathrm{O}_{2}$ and $\mathrm{HO}_{2}$ and from there discuss the chemistry of $\mathrm{OH}$.

\section{Hydrogen Peroxide}

Hydrogen peroxide is very soluble in water, and a large fraction of $\mathrm{H}_{2} \mathrm{O}_{2}(\mathrm{~g})$ initially present is scavenged by the droplets upon cloud formation. In addition, $\mathrm{H}_{2} \mathrm{O}_{2}(\mathrm{aq})$ is produced within the aqueous phase by recombination of perhydroxyl radicals. The rate of aqueous-phase $\mathrm{H}_{2} \mathrm{O}_{2}(\mathrm{aq})$ production is enhanced considerably by partial dissociation of $\mathrm{HO}_{2}(\mathrm{aq})$ to $\mathrm{O}_{2}{ }^{-}$, because of rapid electron transfer between $\mathrm{HO}_{2}(\mathrm{aq})$ and $\mathrm{O}_{2}^{-}$:

$$
\mathrm{HO}_{2}+\mathrm{O}_{2}^{-} \stackrel{-\mathrm{H}_{2} \mathrm{O}}{\rightarrow} \mathrm{H}_{2} \mathrm{O}_{2}+\mathrm{O}_{2}+\mathrm{OH}^{-}
$$

In a cloud, aqueous-phase production of $\mathrm{H}_{2} \mathrm{O}_{2}$ (aq) by (RA22) is much faster than production of $\mathrm{H}_{2} \mathrm{O}_{2}(\mathrm{~g})$ by the analogous gas-phase reaction $\mathrm{HO}_{2}+\mathrm{HO}_{2}$ (Figure 2). Further, (RA22) is faster than gas-phase production of $\mathrm{H}_{2} \mathrm{O}_{2}(\mathrm{~g})$ in the initially clear atmosphere. Therefore $\mathrm{H}_{2} \mathrm{O}_{2}$ production is enhanced by the presence of cloud. The importance of aqueous-phase $\mathrm{H}_{2} \mathrm{O}_{2}$ production in clouds has been discussed by Chameides [1984].

Oxidation of $\mathrm{S}(\mathrm{IV})$ can be a very rapid sink for $\mathrm{H}_{2} \mathrm{O}_{2}(\mathrm{aq})$ because the reaction

(RA107)

$$
\mathrm{HSO}_{3}{ }^{-}+\mathrm{H}_{2} \mathrm{O}_{2}+\mathrm{H}^{+} \rightarrow \mathrm{SO}_{4}{ }^{2-}+2 \mathrm{H}^{+}+\mathrm{H}_{2} \mathrm{O}
$$

is fast. In polluted environments where $\mathrm{SO}_{2}$ is in excess of $\mathrm{H}_{2} \mathrm{O}_{2}$, (RA107) would deplete $\mathrm{H}_{2} \mathrm{O}_{2}$ from the atmosphere on a time scale of minutes [Jacob and Hoffmann, 1983; Seigneur and Saxena, 1984]. In the remote troposphere, however, $\mathrm{H}_{2} \mathrm{O}_{2}$ is in large excess of $\mathrm{SO}_{2}$, so that the extent of $\mathrm{H}_{2} \mathrm{O}_{2}$ depletion by (RA107) is limited by the amount of $\mathrm{SO}_{2}$ present. The present simulation assumes initial concentrations of 8.3 $\times 10^{10}$ molecules $\mathrm{cm}^{-3}$ air $(3.4 \mathrm{ppb})$ and $2.5 \times 10^{9}$ molecules $\mathrm{cm}^{-3}$ air $(0.1 \mathrm{ppb})$ for $\mathrm{H}_{2} \mathrm{O}_{2}$ and $\mathrm{SO}_{2}$, respectively; under those conditions, (RA107) may remove at most $3 \%$ of the $\mathrm{H}_{2} \mathrm{O}_{2}$ initially present. After 1 hour of cloud, $\mathrm{SO}_{2}$ has been nearly quantitatively oxidized and (RA107) has become a negligible sink for $\mathrm{H}_{2} \mathrm{O}_{2}$.

Hydrogen peroxide oxidizes other species in the aqueous phase besides S(IV), but all these reactions are very slow at atmospheric concentrations (Table 2c). The main chemical sinks for $\mathrm{H}_{2} \mathrm{O}_{2}$ (aq), 1 hour after cloud formation, are photolysis and oxidation by $\mathrm{OH}(\mathrm{aq})$, both of which drive the aqueousphase odd $\mathrm{H}$ cycle:

$$
\begin{gathered}
\mathrm{H}_{2} \mathrm{O}_{2}+h v \rightarrow 2 \mathrm{OH} \\
\mathrm{OH}+\mathrm{H}_{2} \mathrm{O}_{2} \rightarrow \mathrm{H}_{2} \mathrm{O}+\mathrm{HO}_{2}
\end{gathered}
$$

Removal of $\mathrm{H}_{2} \mathrm{O}_{2}$ (aq) by (RA14) and (RA17) is slower than aqueous-phase production of $\mathrm{H}_{2} \mathrm{O}_{2}$ (aq) by (RA22). Therefore $\mathrm{H}_{2} \mathrm{O}_{2}$ (aq) produced in the droplets is volatilized, and $\mathrm{H}_{2} \mathrm{O}_{2}$ 
TABLE 3. Sources and Sinks of OH(aq) in Cloud

\begin{tabular}{|c|c|c|}
\hline $\begin{array}{l}\text { Reaction } \\
\text { No. }\end{array}$ & Reaction & $\begin{array}{l}\text { Rate, } \\
M \mathrm{~s}^{-1}\end{array}$ \\
\hline $\begin{array}{l}\text { (H2) } \\
\text { (RA14) }\end{array}$ & $\begin{array}{ll}\mathrm{OH}(\mathrm{g}) \rightarrow \underset{\mathrm{OH}(\mathrm{aq})}{ } & \text { Sources } \\
\mathrm{H}_{2} \mathrm{O}_{2}+h v \rightarrow 2 \mathrm{OH} & \end{array}$ & $\begin{array}{c}2.5(-9) \\
(2 x) 5.7(-10)\end{array}$ \\
\hline (RA27) & $\mathrm{O}_{2}^{-}+\mathrm{O}_{3} \rightarrow \mathrm{OH}+2 \mathrm{O}_{2}+\mathrm{OH}^{-}$ & $\begin{array}{l}2.3(-9) \\
5.9(-9)^{a}\end{array}$ \\
\hline & Sinks & \\
\hline (RA44) & $\mathrm{OH}+\mathrm{H}_{2} \mathrm{C}(\mathrm{OH})_{2} \stackrel{\mathrm{O}_{2}}{\rightarrow} \mathrm{HCOOH}+\mathrm{HO}_{2}+\mathrm{H}_{2} \mathrm{O}$ & $2.9(-9)$ \\
\hline (RA17) & $\mathrm{OH}+\mathrm{H}_{2} \mathrm{O}_{2} \rightarrow \underset{\mathrm{O}_{2}}{\mathrm{HO}_{2}}+\mathrm{H}_{2} \mathrm{O}$ & $1.7(-9)$ \\
\hline (RA47) & $\mathrm{OH}+\mathrm{HCOO}^{-} \stackrel{\mathrm{O}_{2}}{\rightarrow} \mathrm{CO}_{2}+\mathrm{HO}_{2}+\mathrm{OH}^{-}$ & $1.2(-9)$ \\
\hline $\begin{array}{l}\text { (RA19) } \\
\text { (RA15) }\end{array}$ & $\begin{array}{l}\mathrm{OH}+\mathrm{Cl}^{-}+\mathrm{H}^{+} \rightarrow \mathrm{Cl}+\mathrm{H}_{2} \mathrm{O} \\
\mathrm{OH}+\mathrm{HO}_{2} \rightarrow \mathrm{O}_{\mathrm{O}_{2}}+\mathrm{H}_{2} \mathrm{O}\end{array}$ & $\begin{array}{l}2.1(-11) \\
4.8(-11)\end{array}$ \\
\hline (RA46) & $\mathrm{OH}+\mathrm{HCOOH} \rightarrow \mathrm{CO}_{2}+\mathrm{HO}_{2}+\mathrm{H}_{2} \mathrm{O}$ & $3.7(-11)$ \\
\hline (RA41) & $\mathrm{OH}+\mathrm{CH}_{3} \mathrm{OH} \stackrel{\mathrm{O}_{2}}{\rightarrow} \mathrm{CH}_{2} \mathrm{O}+\mathrm{HO}_{2}+\mathrm{H}_{2} \mathrm{O}$ & $4.0(-11)$ \\
\hline \multirow[t]{2}{*}{ (RA16) } & $\mathrm{OH}+\mathrm{O}_{2}^{-} \rightarrow \mathrm{O}_{2}+\mathrm{OH}^{-}$ & $2.1(-11)$ \\
\hline & & $5.9(-9)^{b}$ \\
\hline
\end{tabular}

Read 2.5(-9) as $2.5 \times 10^{-9}$. Model conditions are those of Table 1, 1 hour after cloud formation (Figure $2 b$ ).

${ }^{a}$ Total rate for sources.

${ }^{b}$ Total rate for sinks.

accumulates in both the gas phase and the aqueous phase. The rate of $\mathrm{H}_{2} \mathrm{O}_{2}$ accumulation in both phases $\left(1.8 \times 10^{6}\right.$ molecules $\mathrm{cm}^{-3}$ air s $\mathrm{s}^{-1}$ ) is still fairly slow compared to the initial $\mathrm{H}_{2} \mathrm{O}_{2}$ concentration $\left(8.3 \times 10^{10}\right.$ molecules $\mathrm{cm}^{-3}$ air $)$, so that $\mathrm{H}_{2} \mathrm{O}_{2}$ concentrations are expected to show little change with time over the typical lifetime of a cloud. Concentrations of $\mathrm{H}_{2} \mathrm{O}_{2}(\mathrm{~g})$ and $\mathrm{H}_{2} \mathrm{O}_{2}(\mathrm{aq})$ in cloud are mostly set by Henry's law partitioning of the initial $\mathrm{H}_{2} \mathrm{O}_{2}$ between the gas phase and the aqueous phase.

\section{Perhydroxyl Radical}

The perhydroxyl radical is very soluble in water, and its solubility is further enhanced by the acid-base dissociation of $\mathrm{HO}_{2}(\mathrm{aq})\left(p \mathrm{~K}_{298}=4.69\right)$ :

$$
\mathrm{HO}_{2}(\mathrm{aq}) \rightleftarrows \mathrm{H}^{+}+\mathrm{O}_{2}^{-}
$$

The species $\mathrm{HO}_{2}(\mathrm{aq})$ and $\mathrm{O}_{2}{ }^{-}$are in rapid equilibrium in the aqueous phase, and it is convenient to define $\mathrm{O}_{2}(-\mathrm{I})$ as their sum:

$$
\left[\mathrm{O}_{2}(-\mathrm{I})\right]=\left[\mathrm{HO}_{2}(\mathrm{aq})\right]+\left[\mathrm{O}_{2}{ }^{-}\right]
$$

In the aqueous phase, $\mathrm{O}_{2}(-\mathrm{I})$ is rapidly removed by electron transfer reactions involving $\mathrm{O}_{2}{ }^{-}$:

$$
\begin{gathered}
\mathrm{O}_{2}^{-}+\mathrm{O}_{3} \stackrel{\mathrm{H}_{2} \mathrm{O}}{\rightarrow} \mathrm{OH}+2 \mathrm{O}_{2}+\mathrm{OH}^{-} \\
\mathrm{HO}_{2}+\mathrm{O}_{2} \stackrel{-}{-\mathrm{H}_{2} \mathrm{O}} \rightarrow \mathrm{H}_{2} \mathrm{O}_{2}+\mathrm{O}_{2}+\mathrm{OH}^{-}
\end{gathered}
$$

If $\mathrm{HO}_{2}(\mathrm{aq})$ did not dissociate (low $p \mathrm{H}$ ), aqueous-phase removal of $\mathrm{O}_{2}(-\mathrm{I})$ would proceed mostly by the reaction $\mathrm{HO}_{2}$ $+\mathrm{HO}_{2}$ (RA21), which is much slower than (RA22). Therefore the partial dissociation of $\mathrm{HO}_{2}(\mathrm{aq})$ enhances the aqueousphase removal of $\mathrm{O}_{2}^{\prime}(-\mathrm{I})$, which in turn enhances the rate of scavenging of $\mathrm{HO}_{2}(\mathrm{~g})$ by the droplets. As a result, the fate of
$\mathrm{HO}_{2}$ in cloud is strongly dependent on the cloud water $p \mathrm{H}$. This will be discussed in the next section.

In the standard simulation $(p \mathrm{H}=4.16)$ the aqueous-phase reactions removing $\mathrm{O}_{2}(-\mathrm{I})$ proceed sufficiently fast that equilibirum between $\mathrm{HO}_{2}(\mathrm{~g})$ and $\mathrm{HO}_{2}(\mathrm{aq})$ is not fully achieved. Mass transport limitations involved in $\mathrm{HO}_{2}$ gas-droplet transfer have been discussed in detail previously by Schwartz [1984]. Scavenging of $\mathrm{HO}_{2}(\mathrm{~g})$ from the gas phase constitutes the main source of $\mathrm{O}_{2}(-\mathrm{I})$, but aqueous-phase oxidation of $\mathrm{H}_{2} \mathrm{C}(\mathrm{OH})_{2}, \mathrm{H}_{2} \mathrm{O}_{2}(\mathrm{aq})$, and $\mathrm{HCOO}^{-}$by $\mathrm{OH}(\mathrm{aq})$ provide important secondary sources of $\mathrm{O}_{2}(-\mathrm{I})$ :

(RA44) $\mathrm{H}_{2} \mathrm{C}(\mathrm{OH})_{2}+\mathrm{OH} \stackrel{\mathrm{O}_{2}}{\rightarrow} \mathrm{HCOOH}+\mathrm{HO}_{2}+\mathrm{H}_{2} \mathrm{O}$

$$
\begin{gathered}
\mathrm{OH}+\mathrm{H}_{2} \mathrm{O}_{2} \rightarrow \mathrm{H}_{2} \mathrm{O}+\mathrm{HO}_{2} \\
\mathrm{HCOO}^{-}+\mathrm{OH} \rightarrow \mathrm{CO}_{2}+\mathrm{HO}_{2}+\mathrm{OH}^{-}
\end{gathered}
$$

Because of the rapid aqueous-phase removal of $\mathrm{O}_{2}{ }^{-}$the droplets constitute a dynamic sink for $\mathrm{HO}_{2}(\mathrm{~g})$ which is much more rapid than the gas-phase $\mathrm{HO}_{2}(\mathrm{~g})$ sinks. As a result, $\mathrm{HO}_{2}(\mathrm{~g})$ is depleted in the cloud; the concentration of $\mathrm{HO}_{2}(\mathrm{~g})$ in the cloud is only $29 \%$ of the concentration before cloud formation. The scavenging of $\mathrm{HO}_{2}(\mathrm{~g})$ interrupts the gas-phase odd $\mathrm{H}$ cycle by slowing down the conversions $\mathrm{HO}_{2}(\mathrm{~g}) \rightarrow$ $\mathrm{OH}(\mathrm{g})$ and $\mathrm{HO}_{2}(\mathrm{~g}) \rightarrow \mathrm{H}_{2} \mathrm{O}_{2}(\mathrm{~g})$, and instead, drives the aqueous-phase odd $\mathrm{H}$ cycle by the conversions $\mathrm{O}_{2}(-\mathrm{I}) \rightarrow$ $\mathrm{OH}(\mathrm{aq})$ and $\mathrm{O}_{2}(-\mathrm{I}) \rightarrow \mathrm{H}_{2} \mathrm{O}_{2}$ (aq) (reactions (RA27) and (RA22)). We have previously seen that this modification of the odd $\mathrm{H}$ cycle leads to enhanced production of $\mathrm{H}_{2} \mathrm{O}_{2}$ in clouds but has only minor implications on the $\mathrm{H}_{2} \mathrm{O}_{2}$ concentration; as we will now see, the effect on $\mathrm{OH}$ chemistry is considerably more important.

\section{Hydroxyl Radical}

The $\mathrm{OH}$ radical is less soluble than $\mathrm{H}_{2} \mathrm{O}_{2}$ or $\mathrm{HO}_{2}$ (Table 2). However, Figure 2 shows that the concentrations of $\mathrm{OH}(\mathrm{g})$ and $\mathrm{OH}(\mathrm{aq})$ are controlled more by homogeneous sources and sinks than by exchanges at the droplet surface. Therefore the coupling by gas-droplet transfer between gas-phase and aqueous-phase $\mathrm{OH}$ concentrations is less important than in the case of $\mathrm{H}_{2} \mathrm{O}_{2}$ or $\mathrm{HO}_{2}$.

The concentration of $\mathrm{OH}(\mathrm{g})$ in cloud is $25 \%$ lower than the concentration before cloud formation. Gas-phase production of $\mathrm{OH}(\mathrm{g})$ is slowed down in the cloud because of the depletion of $\mathrm{HO}_{2}(\mathrm{~g})$ and $\mathrm{H}_{2} \mathrm{O}_{2}(\mathrm{~g})$. On the other hand, the gas-phase sinks are little affected by cloud because $\mathrm{CO}$ and $\mathrm{CH}_{4}$, the main species removing $\mathrm{OH}(\mathrm{g})$, are not scavenged by the cloud droplets. Loss of $\mathrm{OH}(\mathrm{g})$ by transfer to the aqueous phase is slower than the gas-phase $\mathrm{OH}(\mathrm{g})$ sinks and has only a minor effect on $\mathrm{OH}(\mathrm{g})$ concentrations. Therefore the main cause of the decrease of $\mathrm{OH}(\mathrm{g})$ concentrations in cloud is not the scavenging of $\mathrm{OH}(\mathrm{g})$ but rather the scavenging of $\mathrm{H}_{2} \mathrm{O}_{2}(\mathrm{~g})$ and $\mathrm{HO}_{2}(\mathrm{~g})$.

Table 3 lists the main sources and sinks of $\mathrm{OH}(\mathrm{aq})$ and their rates. The species $\mathrm{H}_{2} \mathrm{O}_{2}(\mathrm{aq})$ and $\mathrm{O}_{2}(-\mathrm{I})$ are important sources of $\mathrm{OH}(\mathrm{aq})$ by (RA14) and (RA27). Scavenging of $\mathrm{OH}(\mathrm{g})$ provides a source of $\mathrm{OH}(\mathrm{aq})$ which is of comparable importance to these two aqueous-phase sources. The main $\mathrm{OH}(\mathrm{aq})$ sinks are the oxidation reactions with $\mathrm{H}_{2} \mathrm{C}(\mathrm{OH})_{2}, \mathrm{H}_{2} \mathrm{O}_{2}(\mathrm{aq})$, and $\mathrm{HCOO}^{-}$, three of the most abundant reduced species.

From Table 3 the chemical lifetime of $\mathrm{OH}(\mathrm{aq})$ is $6.7 \times 10^{-5}$ $\mathrm{s}$. Because of this short lifetime, OH(aq) is poorly mixed within

Fi
dista
Dasł
cond

the
the
OHı
can
proc
redu
The1
appı
gives
exclı
phas
aque
so tł
cent]
face
high
Be
rate
woul
sensi
shor
ulati
sume
OH(
centr
HSC
the c
the F
appe
remo


ir $p \mathrm{H}$.

-phase equillieved. transhwartz titutes ion of de im-

$2^{-}$the s much result, $\mathrm{HO}_{2}(\mathrm{~g})$ a cloud s-phase )$_{2}(\mathrm{~g}) \rightarrow$ 'es the $(-\mathrm{I}) \rightarrow$ 7) and $\mathrm{n}$ of the 1 clouds tration; iderably

Table 2). if $\mathrm{OH}(\mathrm{g})$ rces and fore the ase and than in

than the oduction depletion ;as-phase $\mathrm{CH}_{4}$, the the cloud phase is a minor cause of the scav)$_{2}(\mathrm{~g})$ and

and their it sources $\mathrm{H}(\mathrm{g})$ proaportance (aq) sinks (aq), and 3. $.7 \times 10^{-5}$ red within

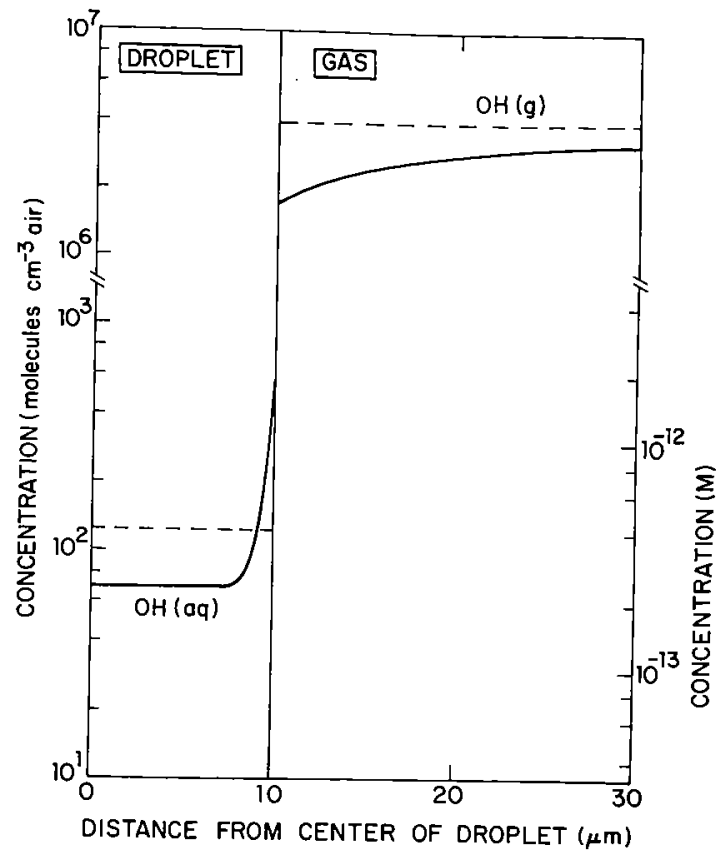

Fig. 3. Concentrations of $\mathrm{OH}(\mathrm{aq})$ and $\mathrm{OH}(\mathrm{g})$ as a function of distance from the center of a droplet, 1 hour after cloud formation. Dashed lines represent bulk concentrations in each phase. Model conditions are those of Table 1.

the droplets (Figure 3). The OH(aq) concentration away from the droplet surface is not affected by gas-droplet transfer; $\mathrm{OH}(\mathrm{g})$ absorbed at the surface of the droplet reacts before it can penetrate to the interior of the droplet, while $\mathrm{OH}(\mathrm{aq})$ produced in the droplet interior by aqueous-phase reactions is reduced before it can be volatilized at the droplet surface. Therefore the concentration of $\mathrm{OH}(\mathrm{aq})$ in the droplet interior approaches an aqueous-phase chemical steady state value given by a balance between aqueous-phase sources and sinks, excluding gas-droplet transfer. From Table 3, the aqueousphase production rate of $\mathrm{OH}(\mathrm{aq})$ is $3.4 \times 10^{-9} \mathrm{M} \mathrm{s}^{-1}$, and the aqueous-phase first-order loss rate constant is $1.5 \times 10^{4} \mathrm{~s}^{-1}$, so that the aqueous-phase chemical steady state $\mathrm{OH}(\mathrm{aq})$ concentration in the droplet interior is $2.3 \times 10^{-13} \mathrm{M}$. The surface concentration of $\mathrm{OH}(\mathrm{aq})$ is $1.8 \times 10^{-12} \mathrm{M}, 4.4$ times higher than the bulk concentration $\left(4.0 \times 10^{13} \mathrm{M}\right)$.

Because of the high surface concentration of $\mathrm{OH}(\mathrm{aq})$ the rate of transfer of $\mathrm{OH}(\mathrm{g})$ to the aqueous phase is slower than it would be if $\mathrm{OH}(\mathrm{aq})$ were well mixed in the droplets. The sensitivity of the overall chemistry to the poor mixing of short-lived species was examined by conducting the same simulation as above but with $\mathrm{O}_{3}(\mathrm{aq}), \mathrm{NO}_{3}(\mathrm{aq})$, and $\mathrm{OH}(\mathrm{aq})$ assumed to be well mixed in the droplets. That simulation gave $\mathrm{OH}(\mathrm{aq})$ concentrations $21 \%$ too high and $\mathrm{OH}(\mathrm{g})$ concentrations $5 \%$ too low. The concentrations of $\mathrm{HCOOH}$ and $\mathrm{HSO}_{5}{ }^{-}$were $11 \%$ and $18 \%$ too high, respectively. None of the other species were affected by more than $10 \%$. Therefore the poor mixing of short-lived aqueous-phase species does not appear to be a major factor in the overall chemistry of a remote cloud.

\section{The Methane Oxidation Chain and THE Production of Formic ACID}

Methane is converted to $\mathrm{CO}_{2}$ in the gas phase by a series of successive oxidation steps involving $\mathrm{OH}(\mathrm{g})$ [Logan et al.,
1981]. Figure $4 a$ shows the $\mathrm{CH}_{4}$ oxidation chain in the clear atmosphere preceding the cloud, with the standard model conditions (Table 1). Cloud formation perturbs the $\mathrm{CH}_{4}$ oxidation chain by scavenging of water-soluble intermediates $\left(\mathrm{CH}_{3} \mathrm{O}_{2}\right.$, $\mathrm{CH}_{3} \mathrm{OOH}, \mathrm{CH}_{2} \mathrm{O}, \mathrm{HCOOH}$ ). A parallel oxidation chain is set up in the aqueous phase as these scavenged intermediates react with aqueous-phase odd $\mathrm{H}$ species.

Figure $4 b$ shows the $\mathrm{CH}_{4}$ oxidation chain 1 hour after cloud formation. The initial attack of $\mathrm{OH}(\mathrm{g})$ on $\mathrm{CH}_{4}$ to produce $\mathrm{CH}_{3} \mathrm{O}_{2}$ is slower than before cloud formation because of the lower $\mathrm{OH}(\mathrm{g})$ concentration. The gas-phase reaction of $\mathrm{CH}_{3} \mathrm{O}_{2}(\mathrm{~g})$ with $\mathrm{NO}(\mathrm{g})$ to produce $\mathrm{CH}_{2} \mathrm{O}(\mathrm{g})$ is not inhibited by cloud formation because of the low solubility of $\mathrm{NO}$; on the other hand, the gas-phase reaction of $\mathrm{CH}_{3} \mathrm{O}_{2}(\mathrm{~g})$ with $\mathrm{HO}_{2}(\mathrm{~g})$ to produce $\mathrm{CH}_{3} \mathrm{OOH}(\mathrm{g})$ is inhibited because of the depletion of $\mathrm{HO}_{2}(\mathrm{~g})$. The Henry's law constant for $\mathrm{CH}_{3} \mathrm{O}_{2}$ is estimated to be of order unity (Table $2 a$ ), so that the droplets do not constitute a significant $\mathrm{CH}_{3} \mathrm{O}_{2}$ sink. In the aqueous phase, $\mathrm{CH}_{3} \mathrm{O}_{2}(\mathrm{aq})$ should react rapidly with $\mathrm{O}_{2}{ }^{-}$to produce $\mathrm{CH}_{3} \mathrm{OOH}(\mathrm{aq})$ :

(RA37) $\mathrm{CH}_{3} \mathrm{O}_{2}+\mathrm{O}_{2} \stackrel{-}{-} \stackrel{\mathrm{H}_{2} \mathrm{O}}{\rightarrow} \mathrm{CH}_{3} \mathrm{OOH}+\mathrm{O}_{2}+\mathrm{OH}^{-}$

The main sink for $\mathrm{CH}_{3} \mathrm{OOH}(\mathrm{aq})$ is volatilization to the gas phase, where it may cycle back to $\mathrm{CH}_{3} \mathrm{O}_{2}(\mathrm{~g})$ or be converted to $\mathrm{CH}_{2} \mathrm{O}(\mathrm{g})$. Oxidation of $\mathrm{HSO}_{3}{ }^{-}$by $\mathrm{CH}_{3} \mathrm{OOH}(\mathrm{aq})$ is unimportant past the first few minutes of cloud, because of the total depletion of $\mathrm{SO}_{2}$.

The aqueous phase is not a significant source of $\mathrm{CH}_{2} \mathrm{O}$; oxidation of $\mathrm{CH}_{3} \mathrm{OOH}(\mathrm{aq})$ and $\mathrm{CH}_{3} \mathrm{OH}(\mathrm{aq})$ contribute less than $1 \%$ of the total $\mathrm{CH}_{2} \mathrm{O}$ produced in cloud. On the other hand, cloud droplets provide an important sink for $\mathrm{CH}_{2} \mathrm{O}$ produced in the gas phase. Formaldehyde is very soluble in water because it hydrates to its diol form, methylene glycol:

(RA10)

$$
\mathrm{CH}_{2} \mathrm{O} \stackrel{\mathrm{H}_{2} \mathrm{O}}{\rightleftarrows} \mathrm{H}_{2} \mathrm{C}(\mathrm{OH})_{2}
$$

The equilibrium constant for (RA10) is $1.8 \times 10^{3}$, so that $\mathrm{CH}_{2} \mathrm{O}$ in cloud water is almost totally present as $\mathrm{H}_{2} \mathrm{C}(\mathrm{OH})_{2}$. Methylene glycol does not photolyze but is rapidly oxidized by $\mathrm{OH}(\mathrm{aq})$ to produce $\mathrm{HCOOH}$ via (RA44). Therefore cloud formation introduces an important $\mathrm{CH}_{2} \mathrm{O}$ sink as $\mathrm{H}_{2} \mathrm{C}(\mathrm{OH})_{2}$ oxidized by $\mathrm{OH}(\mathrm{aq})$ is replenished by scavenging of $\mathrm{CH}_{2} \mathrm{O}(\mathrm{g})$. This droplet sink results in the slow depletion of $\mathrm{CH}_{2} \mathrm{O}$ in cloud, on a time scale of several hours.

Aqueous-phase production of $\mathrm{HCOOH}$ by the reaction $\mathrm{H}_{2} \mathrm{C}(\mathrm{OH})_{2}+\mathrm{OH}$ is 3 orders of magnitude faster than gasphase production. Over the first few minutes of cloud, this aqueous-phase source produces more $\mathrm{HCOOH}$ than was initially present in the gas phase. Therefore the $\mathrm{HCOOH}$ concentration in cloud becomes rapidly independent of the initial amount of atmospheric $\mathrm{HCOOH}$. Under cloud-free conditions the lifetime of $\mathrm{HCOOH}$ against oxidation by $\mathrm{OH}(\mathrm{g})$ is several weeks; depending on the frequency of clouds and rain at a given location, one may expect clouds to control the atmospheric concentration of $\mathrm{HCOOH}$. The importance of clouds as a source of $\mathrm{HCOOH}$ has been pointed out previously by Chameides [1984] and Adewuyi et al. [1984].

Clouds are not only a rapid source of $\mathrm{HCOOH}$ but also a rapid sink. The aqueous-phase sink $\left(\mathrm{HCOO}^{-}+\mathrm{OH}\right)$ is 3 orders of magnitude faster than the gas-phase sink $(\mathrm{HCOOH}+\mathrm{OH})$. Therefore the cloud is not an efficient source of $\mathrm{HCOOH}$ if the $\mathrm{HCOOH}$ produced remains in the 

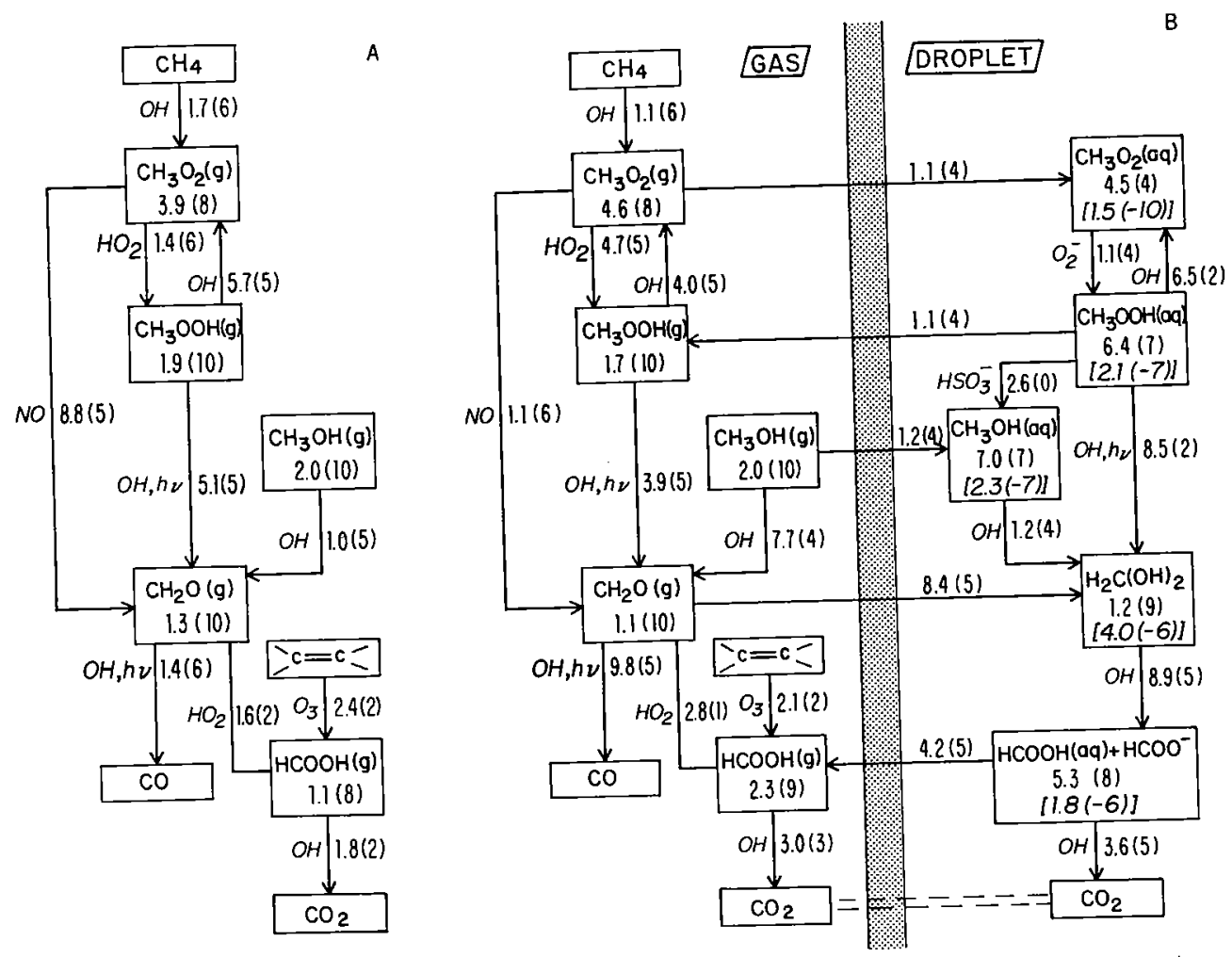

4. The mefore cloud formation and $(b) 1$ hour after cloud formation.

Fig. 4. The methane oxidation chain (a) immediatelon are in units of Model conditions are those of Table 1. The main reaction pathways are indicated. Concer cubic centimeter of air per molecules per cubic centimeter of air and transformation rates are in units of molecules per are given as net fluxes; all second. Aqueous-phase concentrations $(M)$ are given
species are within $1 \%$ of equilibrium by Henry's law.

aqueous phase. Formic acid produced in the aqueous phase can be stabilized by volatilizing to the gas phase, where it has a long lifetime against oxidation by $\mathrm{OH}(\mathrm{g})$. The volatilization of $\mathrm{HCOOH}$ depends on the degree of $\mathrm{HCOOH}(\mathrm{aq}) / \mathrm{HCOO}^{-}$ dissociation in the droplet $\left(p \mathrm{~K}_{298}=3.75\right)$ and is thus strongly $p \mathrm{H}$ dependent. In the standard simulation shown in Figure 4, most of the $\mathrm{HCOOH}$ produced in the droplets volatilizes; after 1 hour of cloud, $\mathrm{HCOOH}$ has accumulated in the gas phase to $2.3 \times 10^{9}$ molecules $\mathrm{cm}^{-3}(0.09 \mathrm{ppb})$. The cloud water $p \mathrm{H}$ in this simulation is low $(p \mathrm{H}=4.16)$, which facilitates the volatilization of $\mathrm{HCOOH}$ and its subsequent accumulation. At higher $p \mathrm{H}$, accumulation of $\mathrm{HCOOH}$ would be much less efficient, as is discussed later.

The value of the Henry's Law constant for $\mathrm{HCOOH}$ is uncertain at this date. In the model, $K_{\mathrm{H} 9}=3.7 \times 10^{3} \mathrm{M}$ atm $^{-1}$ at $298 \mathrm{~K}$ is used, which was calculated from free energy data for $\mathrm{HCOOH}(\mathrm{g})$ and $\mathrm{HCOOH}(\mathrm{aq})$ compiled by Latimer [1952]. Two more recent compilations give slightly different values for the free energies of formation of $\mathrm{HCOOH}(\mathrm{g})[$ Chao and Zwolinski, 1978] and $\mathrm{HCOOH}(\mathrm{aq})$ [Wagman et al., 1982]. From these data one calculates $K_{\mathrm{H} 9}=5.6 \times 10^{3} \mathrm{M} \mathrm{atm}^{-1}$. This discrepancy appears to be within the uncertainties on the free energy data. The sensitivity of the model results to the value selected for $K_{\mathrm{H} 9}$ was tested by running a simulation with standard conditions (Table 1), but with $K_{\mathrm{H} 9}=5.6 \times 10^{3} \mathrm{M}$ $\mathrm{atm}^{-1}$. Concentrations of $\mathrm{HCOOH}(\mathrm{g})$ and $\mathrm{HCOO}^{-} 1$ hour after cloud formation were $18 \%$ lower and $23 \%$ higher than in the standard simulation, respectively. Concentrations of all other species differed by less than $5 \%$. Therefore the model results show little sensitivity to the uncertainty on $K_{\mathrm{H} 9}$.

\section{OXIDATION OF S(IV) вY OH(aq)}

Sulfur dioxide is absorbed by cloud droplets and dissociates in the aqueous phase:

$$
\begin{gathered}
\stackrel{\mathrm{H}_{2} \mathrm{O}}{\mathrm{SO}_{2}(\mathrm{~g}) \rightleftarrows \mathrm{SO}_{2} \cdot \mathrm{H}_{2} \mathrm{O}} \\
\mathrm{SO}_{2} \cdot \mathrm{H}_{2} \mathrm{O} \rightleftarrows \mathrm{H}^{+}+\mathrm{HSO}_{3}{ }^{-} \\
\mathrm{HSO}_{3}{ }^{-} \rightleftarrows \mathrm{H}^{+}+\mathrm{SO}_{3}{ }^{2-}
\end{gathered}
$$

Oxidation of $\mathrm{HSO}_{3}{ }^{-}$and $\mathrm{SO}_{3}{ }^{2-}$ by $\mathrm{OH}(\mathrm{aq})$ produces the $\mathrm{SO}_{3}{ }^{-}$radical [Dogliotti and Hayon, 1968]:

$$
\begin{aligned}
& \mathrm{HSO}_{3}{ }^{-}+\mathrm{OH} \rightarrow \mathrm{SO}_{3}{ }^{-}+\mathrm{H}_{2} \mathrm{O} \\
& \mathrm{SO}_{3}{ }^{2-}+\mathrm{OH} \rightarrow \mathrm{SO}_{3}{ }^{-}+\mathrm{OH}^{-}
\end{aligned}
$$

Under atmospheric conditions, $\mathrm{SO}_{3}{ }^{-}$rapidly adds $\mathrm{O}_{2}$ [Huie and Neta, 1984]:

(RA80)

$$
\mathrm{SO}_{3}{ }^{-}+\mathrm{O}_{2} \rightarrow \mathrm{SO}_{5}
$$

The radical $\mathrm{SO}_{5}{ }^{-}$is a mild oxidant $\left(E\left(\mathrm{SO}_{5}{ }^{-} / \mathrm{HSO}_{5}{ }^{-}\right)=1.1\right.$ V; Huie and Neta, [1984]). McElroy [1986] has suggested that $\mathrm{SO}_{5}{ }^{-}$would rapidly oxidize $\mathrm{Cl}^{-}$, but this reaction does not appear to be thermodynamically favorable. Instead, I expect the main sinks for $\mathrm{SO}_{5}{ }^{-}$in a remote cloud to be the exothermic reactions with $\mathrm{O}_{2}{ }^{-}, \mathrm{HCOO}^{-}$, and $\mathrm{HSO}_{3}{ }^{-}$:

$$
\begin{aligned}
& \mathrm{SO}_{5}{ }^{-}+\mathrm{O}_{2}^{-} \stackrel{\mathrm{H}_{2} \mathrm{O}}{\rightarrow} \mathrm{HSO}_{5}{ }^{-}+\mathrm{OH}^{-}+\mathrm{O}_{2} \\
& \mathrm{SO}_{5}{ }^{-}+\mathrm{HCOO}^{-} \stackrel{\mathrm{O}_{2}}{\rightarrow} \mathrm{HSO}_{5}{ }^{-}+\mathrm{CO}_{2}+\mathrm{O}_{2}
\end{aligned}
$$


(RA81a)

$$
\begin{aligned}
& \mathrm{SO}_{5}{ }^{-}+\mathrm{HSO}_{3}{ }^{-} \rightarrow \mathrm{HSO}_{5}{ }^{-}+\mathrm{SO}_{3}{ }^{-} \\
& \mathrm{SO}_{5}{ }^{-}+\mathrm{HSO}_{3}{ }^{-} \rightarrow \mathrm{SO}_{4}{ }^{-}+\mathrm{SO}_{4}{ }^{2-}+\mathrm{H}^{+} \\
& \mathrm{SO}_{5}{ }^{-}+\mathrm{HSO}_{3}{ }^{-} \rightarrow 2 \mathrm{HO}_{4}{ }^{2-}+2 \mathrm{H}^{+}+\mathrm{OH}
\end{aligned}
$$

(RA81b)

(RA81c)

Caro's acid, $\mathrm{H}_{2} \mathrm{SO}_{5}$, is produced by (RA82) and (RA84), and by $(\mathrm{RA} 81 a)$. The first and second $p \mathrm{Ks}$ for $\mathrm{H}_{2} \mathrm{SO}_{5}$ are $<2$ and 10 , respectively $[K y r k i, 1963]$; at the $p \mathrm{H}$ values found in cloud, the species present is $\mathrm{HSO}_{5}{ }^{-}$(peroxymonosulfate). Peroxymonosulfate is a strong oxidant $\left(E\left(\mathrm{HSO}_{5}{ }^{-} / \mathrm{HSO}_{4}{ }^{-}\right)=\right.$ $1.82 \mathrm{~V}$; Steele and Appelman [1982]). Hydrogen peroxide has a similar redox potential $\left(E\left(\mathrm{H}_{2} \mathrm{O}_{2} / \mathrm{H}_{2} \mathrm{O}\right)=1.77 \mathrm{~V}\right.$; Latimer [1952]). The chemical properties of $\mathrm{HSO}_{5}{ }^{-}$should follow those of $\mathrm{H}_{2} \mathrm{O}_{2}(\mathrm{aq})$, so I expect the main sinks to be reduction of $\mathrm{OH}(\mathrm{aq})$ and oxidation of $\mathrm{HSO}_{3}{ }^{-}$:

(RA86)

$$
\begin{gathered}
\mathrm{HSO}_{5}{ }^{-}+\mathrm{OH} \rightarrow \mathrm{SO}_{5}{ }^{-}+\mathrm{H}_{2} \mathrm{O} \\
\mathrm{HSO}_{5}{ }^{-}+\mathrm{HSO}_{3}{ }^{-} \rightarrow 2 \mathrm{SO}_{4}{ }^{2-}+2 \mathrm{H}^{+}
\end{gathered}
$$

Peroxymonosulfate also oxidizes $\mathrm{Cl}^{-}$[Fortnum et al., 1962] and $\mathrm{NO}_{2}{ }^{-}$[Edwards and Mueller, 1962] by nucleophilic displacement on oxygen, but these reactions are slow at atmospheric concentrations. Decomposition by self-reaction $\left(\mathrm{HSO}_{5}{ }^{-}+\mathrm{SO}_{5}{ }^{2-}\right)$ is very slow at atmospheric concentrations [Edwards, 1964]. Oxidation of $\mathrm{HSO}_{5}{ }^{-}$by $\mathrm{OH}(\mathrm{aq})$ proceeds with a rate constant similar to that for the oxidation of $\mathrm{H}_{2} \mathrm{O}_{2}$ (aq) [Maruthamuthu and Neta, 1977].

No kinetic data are available for the oxidation of S(IV) by $\mathrm{HSO}_{5}{ }^{-}$. Devuyst et al. [1979] have reported that the oxidation by air of a $\mathrm{Na}_{2} \mathrm{SO}_{3}$ solution at $p \mathrm{H}>8$ yields significant concentrations of a stable oxidant with the properties of $\mathrm{HSO}_{5}{ }^{-}$; the yield of this oxidant is zero below $p \mathrm{H} 8$ and increases with $p \mathrm{H}$ above $p \mathrm{H} 8$. This result suggests that the oxidation of S(IV) by $\mathrm{HSO}_{5}{ }^{-}$is an acid-catalyzed reaction, similar to oxidation by other peroxides such as $\mathrm{H}_{2} \mathrm{O}_{2}$ (aq) or $\mathrm{CH}_{3} \mathrm{OOH}(\mathrm{aq})$ (J. A. Lind et al., unpublished manuscript, 1986). In the present mechanism it is assumed that the rate law for (RA86) is the same as that for the oxidation of S(IV) by $\mathrm{H}_{2} \mathrm{O}_{2}$ (aq).

The branching ratio (RA81a):(RA81b):(RA81c) is uncertain at this date. The results of Devuyst et al. [1979] suggest that the pathway (RA81a) is important. Pathway (RA81a) propagates a chain reaction in which $\mathrm{HSO}_{3}{ }^{-}$is oxidized to $\mathrm{HSO}_{5}{ }^{-}$ by the addition of $\mathrm{O}_{2}(\mathrm{aq})$. Pathway (RA81b) produces $\mathrm{SO}_{4}{ }^{-}$, which can also propagate the $\mathrm{S}$ (IV) oxidation chain by reacting with $\mathrm{HSO}_{3}{ }^{-}$, following (RA91). However, $\mathrm{SO}_{4}{ }^{-}$is a very strong oxidant [Maruthamuthu and Neta, 1978] and is more likely to terminate the chain by oxidation of species more abundant than $\mathrm{HSO}_{3}{ }^{-}$, in particular, $\mathrm{Cl}^{-}[M c E l r o y, 1986]$. Therefore pathway (RA81a) is a more effective propagation step than (RA81b).

More generally, the efficiency with which the S(IV) oxidation chain is propagated is determined by the relative abundances of S(IV) on the one hand and other oxidizable species on the other hand. In the remote troposphere, S(IV) constitutes only a small fraction of total oxidizable material and is rapidly depleted by $\mathrm{H}_{2} \mathrm{O}_{2}$. The species $\mathrm{H}_{2} \mathrm{C}(\mathrm{OH})_{2}, \mathrm{HCOO}^{-}$, $\mathrm{Cl}^{-}$, and $\mathrm{H}_{2} \mathrm{O}_{2}(\mathrm{aq})$ are all more abundant than $\mathrm{S}(\mathrm{IV})$ and compete for oxidation by $\mathrm{SO}_{4}{ }^{-}$. The species $\mathrm{O}_{2}{ }^{-}$and $\mathrm{HCOO}^{-}$compete with $\mathrm{S}(\mathrm{IV})$ for oxidation by $\mathrm{SO}_{5}{ }^{-}$. Therefore little chain propagation is expected. In polluted environments, however, S(IV) is one of the most abundant oxidizable species and is present in excess of $\mathrm{H}_{2} \mathrm{O}_{2}$. Under such conditions, oxidation of S(IV) by $\mathrm{OH}(\mathrm{aq})$ may be very efficient at producing $\mathrm{HSO}_{5}{ }^{-}$and $\mathrm{SO}_{4}{ }^{2-}$, even under acidic conditions, because of the propagation of the oxidation chain.

The role of OH(aq) in the oxidation of S(IV) is particularly important when $\mathrm{S}(\mathrm{IV})$ is present as a $\mathrm{S}(\mathrm{IV})-\mathrm{CH}_{2} \mathrm{O}$ adduct, hydroxymethanesulfonate (HMSA). Above $p \mathrm{H} \mathrm{3,} \mathrm{HMSA} \mathrm{is}$ mostly produced by the reaction of $\mathrm{SO}_{3}{ }^{2-}$ with nonhydrated $\mathrm{CH}_{2} \mathrm{O}(\mathrm{aq})$ [Boyce and Hoffmann, 1984]:

(RA75)

$$
\mathrm{SO}_{3}{ }^{2-}+\mathrm{CH}_{2} \mathrm{O} \stackrel{\mathrm{H}_{2} \mathrm{O}}{\rightarrow} \mathrm{HOCH}_{2} \mathrm{SO}_{3}{ }^{-}+\mathrm{OH}^{-}
$$

Recent kinetic studies [Kok et al., 1986; Deister et al., 1986] suggest that dissociation of HMSA proceeds by nucleophilic displacement of $\mathrm{HSO}_{3}{ }^{-}$by $\mathrm{OH}^{-}$[Munger et al., 1986]:

$$
\mathrm{HOCH}_{2} \mathrm{SO}_{3}{ }^{-}+\mathrm{OH}^{-} \rightarrow \mathrm{CH}_{2} \mathrm{O}+\mathrm{SO}_{3}{ }^{2-}+\mathrm{H}_{2} \mathrm{O}
$$

This dissociation reaction is rapid under alkaline conditions but is very slow at the $p \mathrm{H}$ values found in cloud; the lifetime of HMSA against dissociation is of the order of 100 hours at $p \mathrm{H} \mathrm{5}$. The formation of HMSA is of particular interest, because HMSA is not oxidized by $\mathrm{H}_{2} \mathrm{O}_{2}(\mathrm{aq})$ [Kok et al., 1986] or $\mathrm{O}_{3}(\mathrm{aq})$ [Hoigne et al., 1985]. Therefore formation of HMSA could stabilize S(IV) in the cloud and has been invoked to explain the observation of high S(IV) concentrations in nighttime fogs [Munger et al., 1984]. However, HMSA is likely to be rapidly oxidized by $\mathrm{OH}(\mathrm{aq})$ in the daytime. M. R. Hoffmann (California Institute of Technology, private communication, 1986) has observed an explosive reaction upon addition of $\mathrm{Fe}^{2+}$ to a solution containing HMSA and $\mathrm{H}_{2} \mathrm{O}_{2}(\mathrm{aq})$, probably due to the decomposition of $\mathrm{H}_{2} \mathrm{O}_{2}(\mathrm{aq})$ to $\mathrm{OH}(\mathrm{aq})$ [Walling, 1975], followed by $\mathrm{OH}(\mathrm{aq})$ attack on HMSA. The oxidation reaction

$$
\mathrm{HOCH}_{2} \mathrm{SO}_{3}{ }^{-}+\mathrm{OH} \rightarrow \mathrm{CH}_{2} \mathrm{O}+\mathrm{SO}_{3}{ }^{-}+\mathrm{H}_{2} \mathrm{O}
$$

initiates the reaction chain discussed above. Based on the bulk $\mathrm{OH}(\mathrm{aq})$ concentration of $4.0 \times 10^{-13} \mathrm{M}$ in the standard simulation and an estimated rate constant of $1.4 \times 10^{9} \mathrm{M}^{--} \mathrm{s}^{-1}$ for (RA79), the lifetime of HMSA in cloud is expected to be of the order of $30 \mathrm{~min}$. Therefore HMSA should be efficiently oxidized by $\mathrm{OH}(\mathrm{aq})$ in clouds under noontime radiation conditions.

\section{Simúlitations Over a Range of Cloud Water $p \mathrm{H}$}

\section{Odd Hydrogen}

The $p \mathrm{~K}$ of the $\mathrm{HO}_{2}(\mathrm{aq}) / \mathrm{O}_{2}{ }^{-}$couple is 4.69 , which is in the range of $p \mathrm{H}$ values found in atmospheric cloud water. Therefore the concentrations of odd $\mathrm{H}$ species are expected to be strongly $p \mathrm{H}$ dependent. The sensitivity to $p \mathrm{H}$ is explored here by a series of simulations using the model conditions of Table 1 but with condensation nuclei of various acidities.

Figure 5 shows the dependence of the concentrations of $\mathrm{OH}$ and $\mathrm{HO}_{2}$ species on cloud water $p \mathrm{H}, 1$ hour after cloud formation. The concentration of $\mathrm{OH}(\mathrm{g})$ shows little sensitivity to $p \mathrm{H}$ because the main source, the reaction $\mathrm{O}\left({ }^{1} D\right)+\mathrm{H}_{2} \mathrm{O}$, and the main sinks, the reactions $\mathrm{OH}+\mathrm{CO}$ and $\mathrm{OH}+\mathrm{CH}_{4}$, do not involve $\mathrm{HO}_{2}$. The reaction $\mathrm{OH}+\mathrm{CO}$ is in turn the main source of $\mathrm{HO}_{2}(\mathrm{~g})$, so that $\mathrm{HO}_{2}(\mathrm{~g})$ production shows little dependence on $p \mathrm{H}$. However, loss of $\mathrm{HO}_{2}(\mathrm{~g})$ by transfer to the droplets increases with increasing $p \mathrm{H}$, because it is driven by the removal of $\mathrm{O}_{2}{ }^{-}$in the aqueous phase. Therefore a steady decrease in $\mathrm{HO}_{2}(\mathrm{~g})$ concentration is found as the $p \mathrm{H}$ rises from 3 to 6 . Above $p \mathrm{H} 6$ the dependence of the $\mathrm{HO}_{2}(\mathrm{~g})$ concentration on $p \mathrm{H}$ becomes progressively weaker; $\mathrm{O}_{2}(-\mathrm{I})$ is 


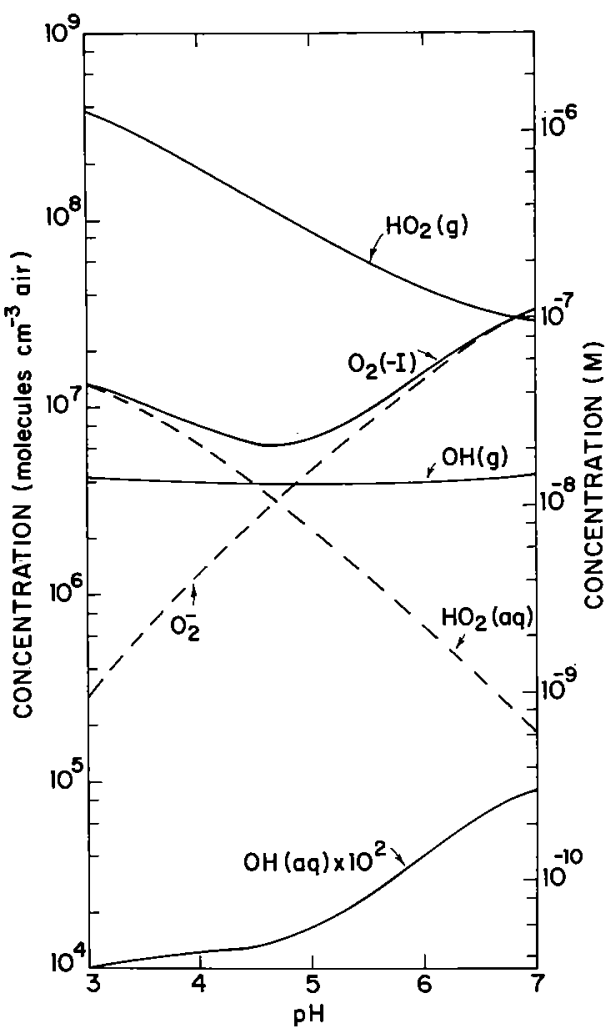

Fig. 5. Concentrations of odd hydrogen species 1 hour after cloud formation, as a function of cloud water $p \mathrm{H}$. Model conditions are those of Table 1. Gas-phase concentrations are in units of molecules per cubic centimeter of air (left-hand scale), and aqueous-phase concentrations are in units of moles per liter of water (right-hand scale). Both scales are equivalent (equation (14)).

then nearly entirely dissociated, so that the droplets behave essentially as a diffusion-limited sink for $\mathrm{HO}_{2}(\mathrm{~g})$.

The concentration of $\mathrm{O}_{2}(-\mathrm{I})$ decreases with increasing $p \mathrm{H}$ up to $p \mathrm{~K}_{\mathrm{HO}_{2}}$. Most of the $\mathrm{O}_{2}(-\mathrm{I})$ in that low $p \mathrm{H}$ range is present as $\mathrm{HO}_{2}(\mathrm{aq})$, so that loss of $\mathrm{O}_{2}(-\mathrm{I})$ by aqueous-phase reactions is slow. Under those conditions, $\mathrm{HO}_{2}$ (aq) approaches Henry's law equilibrium with $\mathrm{HO}_{2}(\mathrm{~g})$, and the dependence of $\mathrm{O}_{2}(-\mathrm{I})$ on $p \mathrm{H}$ follows that of $\mathrm{HO}_{2}(\mathrm{~g})$. At $p \mathrm{H}$ values above $p \mathrm{~K}_{\mathrm{HO}_{2}}$, however, the flux of $\mathrm{HO}_{2}(\mathrm{~g})$ to the droplets is considerably enhanced by the dissociation of $\mathrm{HO}_{2}(\mathrm{aq})$ to $\mathrm{O}_{2}{ }^{-}$, so that the $\mathrm{O}_{2}(-\mathrm{I})$ concentration increases with increasing $p \mathrm{H}$. The concentration of $\mathrm{O}_{2}(-\mathrm{I})$ goes through a

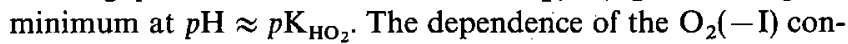
centration on $p \mathrm{H}$ becomes progressively weaker above $p \mathrm{H} 6$, as $\mathrm{O}_{2}(-\mathrm{I})$ then approaches a steady state between production by diffusion-limited scavenging of $\mathrm{HO}_{2}(\mathrm{~g})$ and loss by the reaction $\mathrm{O}_{2}{ }^{-}+\mathrm{O}_{3}$.

The concentration of $\mathrm{OH}(\mathrm{aq})$ increases with increasing $p \mathrm{H}$ because of the increase in $\mathrm{O}_{2}{ }^{-}$concentration, which enhances the rate of $\mathrm{OH}(\mathrm{aq})$ production by the reaction $\mathrm{O}_{2}{ }^{-}+\mathrm{O}_{3}$. The dependence of the $\mathrm{OH}(\mathrm{aq})$ concentration on $p \mathrm{H}$ becomes weaker above $p \mathrm{H} 6$, following the pattern of the $\mathrm{O}_{2}{ }^{-}$concentration. At high $p \mathrm{H}$ the reaction $\mathrm{O}_{2}{ }^{-}+\mathrm{O}_{3}$ is so rapid that $\mathrm{OH}(\mathrm{aq})$ is supersaturated in the droplet and volatilizes to the gas phase. The aqueous phase is then a source of $\mathrm{OH}(\mathrm{g})$; this explains the slight increase in the $\mathrm{OH}(\mathrm{g})$ concentration at high $p \mathrm{H}$.

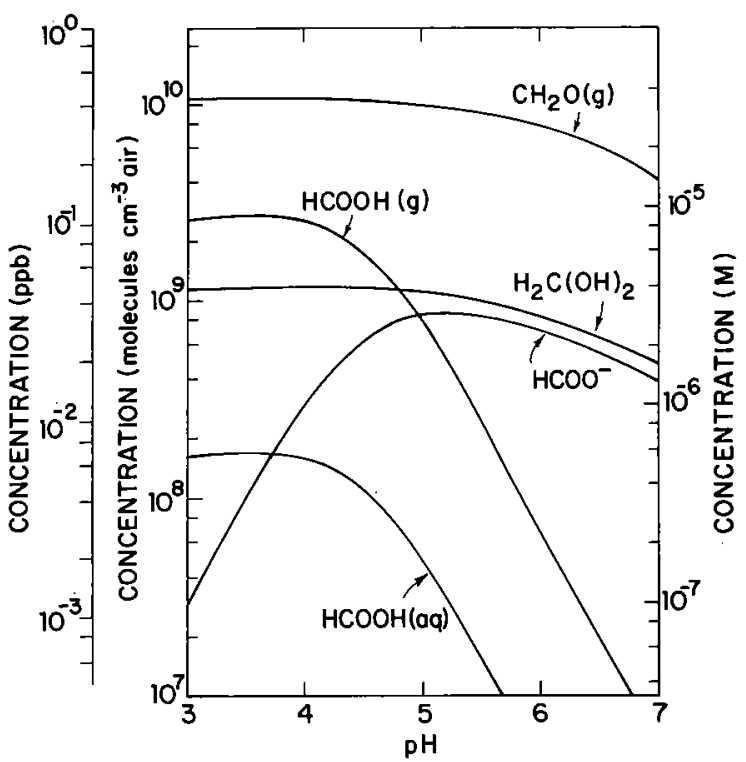

Fig. 6. Concentrations of $\mathrm{CH}_{2} \mathrm{O}$ and $\mathrm{HCOOH}$ species 1 hour after cloud formation, as a function of cloud water $p \mathrm{H}$. Model conditions are those of Table 1. Gas-phase concentrations are in units of molecules per cubic centimeter of air and ppb (left-hand scales), and aqueous-phase concentrations are in units of moles per liter of water (right-hand scale). The scales are equivalent (equation (14)).

\section{Formic Acid}

Figure 6 shows the concentrations of $\mathrm{CH}_{2} \mathrm{O}$ and $\mathrm{HCOOH}$ species 1 hour after cloud formation, as a function of cloud water $p \mathrm{H}$. As the $p \mathrm{H}$ increases and the $\mathrm{OH}(\mathrm{aq})$ concentration increases, the aqueous-phase $\mathrm{HCOOH}$ source, reaction $\mathrm{H}_{2} \mathrm{C}(\mathrm{OH})_{2}+\mathrm{OH}$, also rises. At low $p \mathrm{H}$ most of the $\mathrm{HCOOH}$ produced in the aqueous phase volatilizes to the gas phase, where it has a long lifetime against oxidation by $\mathrm{OH}(\mathrm{g})$. As the $p \mathrm{H}$ increases, however, an increasing fraction of the $\mathrm{HCOOH}$ produced remains in the aqueous phase as $\mathrm{HCOO}^{-}$and is
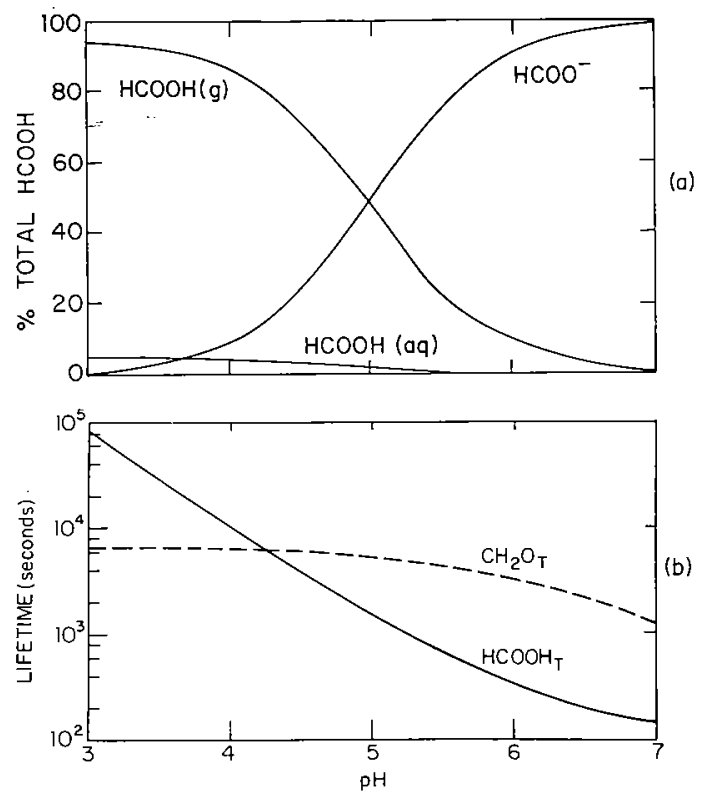

Fig. 7. (a) Equilibrium speciation of $\mathrm{HCOOH}$ in the cloud and $(b)$ chemical lifetimes of $\mathrm{HCOOH}_{T} \quad(=\mathrm{HCOOH}(\mathrm{g})+\mathrm{HCOOH}(\mathrm{aq})$ $\left.+\mathrm{HCOO}^{-}\right)$and $\mathrm{CH}_{2} \mathrm{O}_{\mathrm{T}}\left(=\mathrm{CH}_{2} \mathrm{O}(\mathrm{g})+\mathrm{H}_{2} \mathrm{C}(\mathrm{OH})_{2}\right)$. Model conditions are those of Table 1 . 
oxidized by the rapid reaction $\mathrm{HCOO}^{-}+\mathrm{OH}$. A maximum in the total (gas phase plus aqueous phase) $\mathrm{HCOOH}$ concentration is found at $p \mathrm{H} \approx 3.5$; at that $p \mathrm{H}, \mathrm{HCOOH}$ is mostly in the gas phase. The total $\mathrm{HCOOH}$ concentration decreases rapidly with increasing $p \mathrm{H}$ above $p \mathrm{H} 4$. A maximum in the aqueous-phase $\mathrm{HCOO}^{-}$concentration is found at $p \mathrm{H} \approx 5$.

The dependence of the concentrations of $\mathrm{HCOOH}$ species on $p \mathrm{H}$ can be clearly explained with simple thermodynamic and kinetic arguments. The characteristic time for $\mathrm{HCOOH}$ to equilibrate between the gas phase and the aqueous phase is less than $1 \mathrm{~min}$ for $p \mathrm{H}<7$ [Chameides, 1985]; the oxidation of $\mathrm{HCOO}^{-}$is slower, even at high $\mathrm{pH}$. Therefore the species $\mathrm{HCOOH}(\mathrm{g}), \mathrm{HCOOH}(\mathrm{aq})$, and $\mathrm{HCOO}^{-}$are at equilibrium. The fractions $x, y, z$, of $\mathrm{HCOOH}$ present as $\mathrm{HCOOH}(\mathrm{g})$, $\mathrm{HCOOH}(\mathrm{aq})$, and $\mathrm{HCOO}^{-}$, respectively, are given by

$$
\begin{gathered}
x=\frac{1}{R T \beta} \\
y=\frac{L K_{\mathrm{H} 9}}{\beta} \\
z=\frac{L K_{\mathrm{H} 9} K_{\mathrm{A} 4}}{\beta\left[\mathrm{H}^{+}\right]} \\
\beta=\frac{1}{R T}+L K_{\mathrm{H} 9}\left(1+\frac{K_{\mathrm{A} 4}}{\left[\mathrm{H}^{+}\right]}\right)
\end{gathered}
$$

Figure $7 a$ shows the equilibrium speciation of $\mathrm{HCOOH}$, as a function of $p \mathrm{H}$. Let $\mathrm{HCOOH}_{T}$ represent total (gas phase plus aqueous phase) $\mathrm{HCOOH}$ :

$$
\begin{aligned}
& n_{\mathrm{HCOOH}_{T}}=n_{\mathrm{HCOOH}(\mathrm{g})} \\
& \quad+6.023 \times 10^{20} L\left\{[\mathrm{HCOOH}(\mathrm{aq})]+\left[\mathrm{HCOO}^{-}\right]\right\}
\end{aligned}
$$

The chemical lifetime of $\mathrm{HCOOH}_{T}$ in cloud, $\tau_{\mathrm{HCOOH}_{T}}$, is given by

$$
\tau_{\mathrm{HCOOH}_{T}}=\left\{x k_{\mathrm{G} 13} n_{\mathrm{OH}(\mathrm{g})}+\left(y k_{\mathrm{A} 46}+z k_{\mathrm{A} 47}\right)[\mathrm{OH}(\mathrm{aq})]\right\}^{-1}
$$

This lifetime ranges over almost 2 orders of magnitude be-

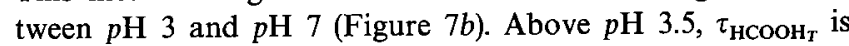
given to a good approximation by the lifetime of $\mathrm{HCOO}^{-}$, that is, loss of $\mathrm{HCOOH}$ in the atmosphere is controlled by the aqueous-phase reaction $\mathrm{HCOO}^{-}+\mathrm{OH}$ :

$$
\tau_{\mathrm{HCOOH}_{T}} \approx\left\{z k_{\mathrm{A} 47}[\mathrm{OH}(\mathrm{aq})]\right\}^{-1}
$$

Chameides [1984] has argued that a steady state in cloud is approached between production of $\mathrm{HCOOH}$ by the aqueousphase source $\mathrm{H}_{2} \mathrm{C}(\mathrm{OH})_{2}+\mathrm{OH}$ and depletion by the aqueousphase sink $\mathrm{HCOO}^{-}+\mathrm{OH}$, so that:

$$
\frac{\left[\mathrm{HCOO}^{-}\right]}{\left[\mathrm{H}_{2} \mathrm{C}(\mathrm{OH})_{2}\right]}=\frac{k_{\mathrm{A} 44}}{k_{\mathrm{A} 47}}
$$

The present calculation indicates that (21) is a correct steady state representation for cloud water $p \mathrm{H}$ values above 3.5 . The characteristic time for reaching this constant ratio between $\mathrm{HCOO}^{-}$and $\mathrm{H}_{2} \mathrm{C}(\mathrm{OH})_{2}$ concentrations is given by $\tau_{\mathrm{HCOOH}_{T}}$ and ranges from 2 min at $p \mathrm{H} 7$ to 8 hours at $p \mathrm{H} 3.5$ (Figure $7 b$ ). Note, however, that the characteristic time for the concentration of $\mathrm{HCOOH}$ to approach a steady state is dependent on the time required for the $\mathrm{H}_{2} \mathrm{C}(\mathrm{OH})_{2}$ concentration to itself approach steady state. Figure $7 b$ shows the chemical lifetime $\tau_{\mathrm{CH}_{2} \mathrm{O}_{T}}$ of total $\mathrm{CH}_{2} \mathrm{O}$ in cloud $\left(\mathrm{CH}_{2} \mathrm{O}(\mathrm{g})\right.$ $\left.+\mathrm{H}_{2} \mathrm{C}(\mathrm{OH})_{2}\right)$, calculated in the same manner as $\tau_{\mathrm{HCOOH}_{T}}$

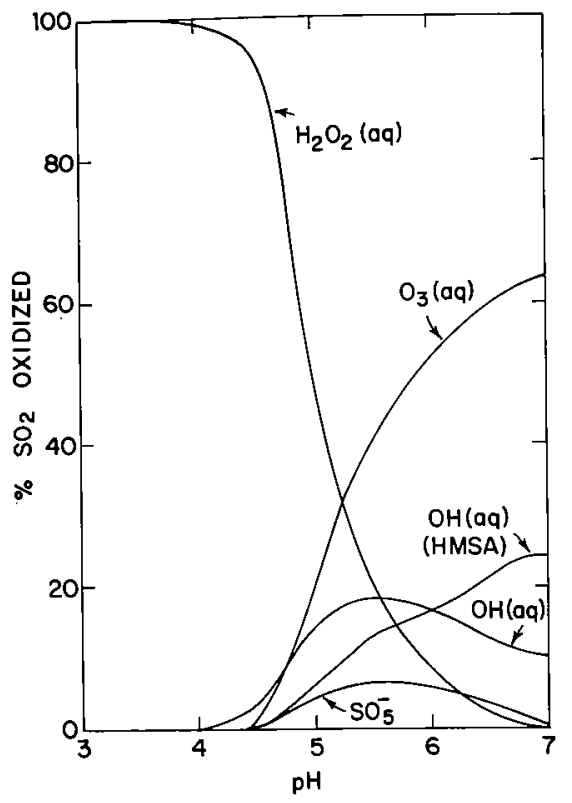

Fig. 8. Contributions of individual aqueous-phase oxidants to the oxidation of $\mathrm{SO}_{2}$, as a function of cloud water $p \mathrm{H}$. The label $\mathrm{OH}$ (HMSA) indicates the oxidation of HMSA by $\mathrm{OH}(\mathrm{aq})$. Model conditions are those of Table 1 .

Above $p \mathrm{H} 4.2, \tau_{\mathrm{CH}_{2} \mathrm{O}_{T}}>\tau_{\mathrm{HCOOH}_{T}}$, so the attainment of a steady state for the concentration of $\mathrm{HCOOH}$ is controlled by $\tau_{\mathrm{CH}_{2} \mathrm{O}_{T}}$. Therefore even at high $p \mathrm{H}$, it takes on the order of 1 hour for $\mathrm{HCOOH}$ to approach a steady state concentration in cloud.

In Figure 6 the steady state ratio (21) between $\mathrm{H}_{2} \mathrm{C}(\mathrm{OH})_{2}$ and $\mathrm{HCOO}^{-}$concentrations, as shown by parallel curves in the concentration versus $p \mathrm{H}$ profiles, is verified only for $p \mathrm{H}>5$. At lower $p \mathrm{H}$ most of the $\mathrm{HCOOH}$ produced in the aqueous phase is volatilized (Figure $7 a$ ), and several hours are required to accumulate sufficient amounts of $\mathrm{HCOO}^{-}$to balance the $\mathrm{H}_{2} \mathrm{C}(\mathrm{OH})_{2}+\mathrm{OH}$ source. This explains the maximum in the $\mathrm{HCOO}^{-}$concentration observed at $p \mathrm{H} \approx 5$. One also notes that the dependence of the $\mathrm{HCOOH}(\mathrm{g})$ concentration on $p \mathrm{H}$ becomes very weak below $p \mathrm{H} 4$; this is because removal of $\mathrm{HCOOH}$ is too slow to be a significant $\mathrm{HCOOH}$ sink during the first hour of cloud. Below $p \mathrm{H} 3.5$ the $\mathrm{HCOOH}(\mathrm{g})$ concentration increases with increasing $p \mathrm{H}$ because the $\mathrm{OH}(\mathrm{aq})$ concentration increases, and therefore the rate of $\mathrm{HCOOH}$ production increases. This explains the maximum in the $\mathrm{HCOOH}(\mathrm{g})$ concentration at $\mathrm{pH} \approx 3.5$.

Data for $\mathrm{HCOO}^{-}$concentrations in precipitation at remote marine sites have been collected by W. C. Keene and J. N. Galloway from the University of Virginia (private communication, 1986). They report volume-weighted average $\mathrm{HCOO}^{-}$ concentrations ranging from 1.4 to $4.2 \mu \mathrm{eq} 1^{-1}$ for three different sites, with rainwater $p \mathrm{H}$ values typically close to 5 . The cloud water $\mathrm{HCOO}^{-}$concentration predicted by the present model at $p \mathrm{H} 5$ is $2.4 \mu \mathrm{eq} \mathrm{L}^{-1}$, which is in the range of the observed rainwater concentrations. Therefore the model results are consistent with the currently available field data.

\section{$S(I V)$ Oxidation}

Complete oxidation of S(IV) proceeds rapidly in a remote cloud because oxidants are present in large excess of $\mathrm{SO}_{2}$. After 1 hour of cloud, over $99 \%$ of the $\mathrm{SO}_{2}$ initially present has been depleted by aqueous-phase oxidation of S(IV). Figure 8 shows the contribution of the different oxidants to the oxi- 


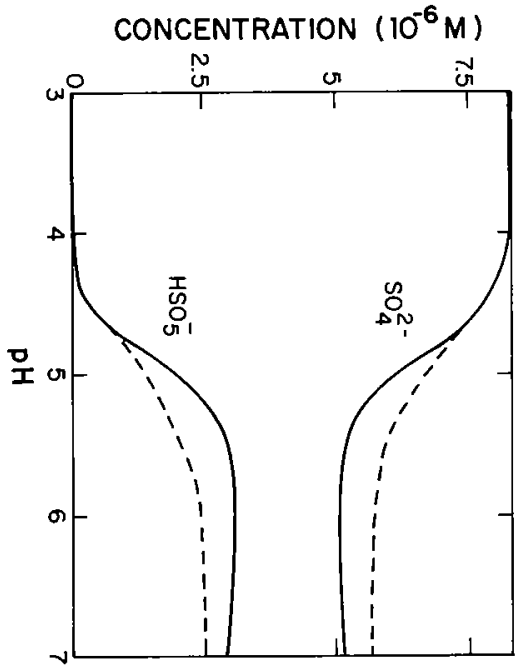

Fig. 9. Concentrations of $\mathrm{SO}_{4}{ }^{2-}$ and $\mathrm{HSO}_{5}{ }^{-} 1$ hour after cloud formation, as a function of cloud water $p \mathrm{H}$. Reaction is assumed to proceed either by branch (RA81a) (solid line), or by branches (RA81b) or (RA81c) (dashed line). Branches (RA81b) and (RA81c) give identical results. Model conditions are those of Table 1.

dation of S(IV), as a function of cloud water $p \mathrm{H}$. At low $p \mathrm{H}$ (condensation on acid nuclei) the only important oxidant is $\mathrm{H}_{2} \mathrm{O}_{2}(\mathrm{aq})$, because the reaction $\mathrm{H}_{2} \mathrm{O}_{2}+\mathrm{HSO}_{3}{ }^{-}$is acid catalyzed [McArdle and Hoffmann, 1983]. At high $p \mathrm{H}$ (condensation on alkaline nuclei), $\mathrm{S}(\mathrm{IV})$ is oxidized by $\mathrm{O}_{3}(\mathrm{aq})$ and $\mathrm{OH}(\mathrm{aq})$ more rapidly than by $\mathrm{H}_{2} \mathrm{O}_{2}$.

The intrinsic rate of oxidation of S(IV) by $\mathrm{O}_{3}(\mathrm{aq})$ is first order in $\mathrm{SO}_{3}{ }^{2-}$ concentration, and therefore the rate increases rapidly with increasing $p \mathbf{H}$. However, the actual reaction rate becomes increasingly limited at high $p \mathrm{H}$ by the rate of aqueous-phase diffusion of $\mathrm{O}_{3}(\mathrm{aq})$. Because of this mass transport limitation in the rate of oxidation of $\mathrm{S}(\mathrm{IV})$ by $\mathrm{O}_{3}(\mathrm{aq})$, $\mathrm{OH}(\mathrm{aq})$ remains an important $\mathrm{S}(\mathrm{IV})$ oxidant even at high $p \mathrm{H}$. Above $p \mathrm{H} 6$ it is predicted that the main S(IV) species oxidized by $\mathrm{OH}(\mathrm{aq})$ is HMSA, which is formed rapidly in the initial stage of the cloud and is not oxidized by $\mathrm{O}_{3}(\mathrm{aq})$.

The only sulfur species present in significant concentrations 1 hour after cloud formation are $\mathrm{SO}_{4}{ }^{2-}$ and $\mathrm{HSO}_{5}{ }^{-}$. Figure 9 shows the concentrations of both species, as a function of cloud water $p \mathrm{H}$. Under acidic conditions only $\mathrm{SO}_{4}{ }^{2-}$ is formed, because $\mathrm{H}_{2} \mathrm{O}_{2}(\mathrm{aq})$ is the only important $\mathrm{S}(\mathrm{IV})$ oxidant. Above $p \mathrm{H} \mathrm{5}$, however, oxidation of $\mathrm{S}(\mathrm{IV})$ by $\mathrm{OH}(\mathrm{aq})$ produces substantial amounts of $\mathrm{HSO}_{5}{ }^{-}$. In the $p \mathrm{H}$ range 5.5-7, $\mathrm{HSO}_{5}{ }^{-}$constitutes about $35 \%$ of total cloud water sulfur. Peroxymonosulfate is reduced to $\mathrm{SO}_{4}{ }^{2-}$ by oxidation of $\mathrm{HSO}_{3}{ }^{-}$, but this reaction is inhibited as $\mathrm{SO}_{2}$ is depleted rapidly in the cloud by reaction of S(IV) with other oxidants (in particular, $\mathrm{O}_{3}(\mathrm{aq})$ ). Therefore $\mathrm{HSO}_{5}{ }^{-}$is not depleted over the lifetime of the cloud. A steady state between $\mathrm{SO}_{5}{ }^{-}$and $\mathrm{HSO}_{5}{ }^{-}$is eventually approached:

$$
\begin{gathered}
\mathrm{SO}_{5}{ }^{-}+\mathrm{O}_{2}{ }^{-} \stackrel{\mathrm{H}_{2} \mathrm{O}}{\rightarrow} \mathrm{HSO}_{5}{ }^{-}+\mathrm{OH}^{-}+\mathrm{O}_{2} \\
\mathrm{HSO}_{5}{ }^{-}+\mathrm{OH} \rightarrow \mathrm{SO}_{5}{ }^{-}+\mathrm{H}_{2} \mathrm{O}
\end{gathered}
$$

Figure 9 indicates that the amount of $\mathrm{HSO}_{5}{ }^{-}$produced is only weakly dependent on the branching ratio of (RA81), $\mathrm{SO}_{5}{ }^{-}+\mathrm{HSO}_{3}{ }^{-}$. This is because ( $\mathrm{RA} 82$ ), $\mathrm{SO}_{5}{ }^{-}+\mathrm{O}_{2}{ }^{-}$, is a faster sink for $\mathrm{SO}_{5}{ }^{-}$than (RA81). Reaction (RA81), propagating the S(IV) oxidation chain, is important only in the very early stage of the cloud when the $\mathrm{HSO}_{3}{ }^{-}$concentration is high. This is illustrated by Figure 8 : the initiation step in the chain, reaction $\mathrm{OH}+\mathrm{S}(\mathrm{IV})$, is a more important contributor to $\mathrm{S}(\mathrm{IV})$ oxidation than the propagation step, reaction $\mathrm{SO}_{5}{ }^{-}$ $+\mathrm{HSO}_{3}{ }^{-}$. (RA81b) and (RA81c) give identical results because $\mathrm{SO}_{4}{ }^{-}$is removed by oxidation of $\mathrm{Cl}^{-}$and $\mathrm{H}_{2} \mathrm{O}_{2}$ (aq) and does not propagate the chain oxidation of $\mathrm{S}(\mathrm{IV})$. The main sinks for $\mathrm{Cl}_{2}{ }^{-}$, produced by the reaction $\mathrm{SO}_{4}{ }^{-}+\mathrm{Cl}^{-}$ are the reactions with $\mathrm{H}_{2} \mathrm{O}_{2}$ and $\mathrm{O}_{2}(-\mathrm{I})$.

\section{Sensitivity to Model Conditions}

\section{Changes in Radiation Field}

The sensitivity of the chemistry to changes in radiation field upon cloud formation was investigated by running two simulations in which the $J$ values were assumed to change upon cloud formation by $+50 \%$ in one case, and $-50 \%$ in the other case (other model conditions as given in Table 1). Results are shown in Table 4.

The concentrations of $\mathrm{OH}(\mathrm{g})$ and $\mathrm{OH}(\mathrm{aq})$ respond almost linearly to changes in the radiation field. This is because the main sources of these species are the photolysis reactions of $\mathrm{O}_{3}$ and $\mathrm{H}_{2} \mathrm{O}_{2}$. The concentrations of $\mathrm{HO}_{2}$ species show a weaker response to changes in radition field, even though the main source of $\mathrm{HO}_{2}$ is the conversion $\mathrm{OH}(\mathrm{g}) \rightarrow \mathrm{HO}_{2}(\mathrm{~g})$. The reason for this weaker response of $\mathrm{HO}_{2}$ species is that the main $\mathrm{HO}_{2}$ sink in cloud, aqueous-phase reaction $\mathrm{HO}_{2}+\mathrm{O}_{2}{ }^{-}$, is second order in $\mathrm{HO}_{2}$ concentration. Therefore an increase in the $\mathrm{HO}_{2}$ source is moderated by a higher-order increase in the $\mathrm{HO}_{2}$ sink.

The $\mathrm{HCOOH}$ concentration increases with a stronger radiation field because of the increase in the $\mathrm{OH}(\mathrm{aq})$ concentration. However, the dependence of the $\mathrm{HCOOH}$ concentration on the radiation field is itself strongly dependent on cloud water $p \mathrm{H}$. At low $p \mathrm{H}$, when $\mathrm{HCOOH}$ produced by the aqueous-phase reaction $\mathrm{H}_{2} \mathrm{C}(\mathrm{OH})_{2}+\mathrm{OH}$ is volatilized, the concentration of $\mathrm{HCOOH}$ responds linearly to changes in the radiation field in the same way as the concentration of $\mathrm{OH}(\mathrm{aq})$. On the other hand, at high $\mathrm{pH}, \mathrm{HCOOH}$ is mostly present as $\mathrm{HCOO}^{-}$, which follows (21); the dependence of the $\mathrm{HCOOH}$ concentration on the radiation field then follows that of the $\mathrm{CH}_{2} \mathrm{O}$ concentration, which is very weak.

\section{Sticking Coefficient, Droplet Radius}

A series of simulations was conducted with the standard conditions of Table 1 , but with $\alpha$ ranging from $10^{-4}$ to 1 (the

TABLE 4. Effect of Changes in the Radiation Field

\begin{tabular}{lccc}
\hline & \multicolumn{3}{c}{$\begin{array}{c}\text { Change in } J \text { Values } \\
\text { Upon Cloud Formation }\end{array}$} \\
\cline { 2 - 4 } Species & $-50 \%$ & $0 \%$ & $+50 \%$ \\
\hline & Concentration, molecules cm ${ }^{-3}$ air \\
$\mathrm{OH}(\mathrm{g})$ & $2.0(6)$ & $3.9(6)$ & $5.9(6)$ \\
$\mathrm{HO}_{2}(\mathrm{~g})$ & $1.2(8)$ & $1.7(8)$ & $2.1(8)$ \\
$\mathrm{HCOOH}_{T}$ & $2.0(9)$ & $2.9(9)$ & $3.5(9)$ \\
$\mathrm{CH}_{2} \mathrm{O}_{T}{ }^{a}$ & $1.2(10)$ & $1.2(10)$ & $1.1(10)$ \\
& \multicolumn{4}{c}{ Concentration, $M$} \\
$\mathrm{OH}(\mathrm{aq})$ & $2.5(-13)$ & $4.1(-13)$ & $5.6(-13)$ \\
$\mathrm{O}_{2}(-\mathrm{I})$ & $1.7(-8)$ & $2.3(-8)$ & $2.9(-8)$ \\
\hline
\end{tabular}

Read $2.0(6)$ as $2.0 \times 10^{6}$. Other conditions are as in Table 1 ; concentrations are taken 1 hour after cloud formation.

${ }^{a}$ The value $\left.n_{\mathrm{CH}_{2} \mathrm{O}_{T}}=n_{\mathrm{CH}_{2} \mathrm{O}(\mathrm{g})}+6.023 \times 10^{20} L\left[\mathrm{H}_{2} \mathrm{ClOH}\right)_{2}\right]$. 


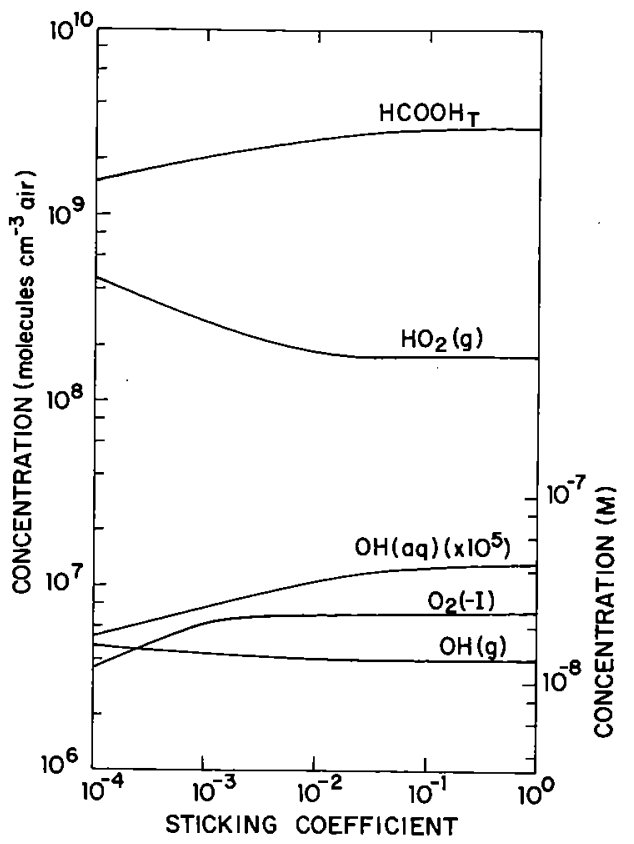

Fig. 10. Concentrations of $\mathrm{OH}, \mathrm{HO}_{2}$, and $\mathrm{HCOOH}_{T} 1$ hour after cloud formation, as a function of sticking coefficient. Other model conditions are those of Table 1. Gas-phase and $\mathrm{HCOOH}_{T}$ concentrations are in units of molecules per cubic centimeter of air (lefthand scale), and aqueous-phase concentrations are in units of moles per liter of water (right-hand scale). Both scales are equivalent (equation (14)).

same value of $\alpha$ was assumed for all gases). Results are shown in Figure 10. The cloud water $p \mathrm{H}$ is controlled by the scavenging of very soluble gases $\left(\mathrm{HNO}_{3}, \mathrm{HCl}, \mathrm{NH}_{3}\right)$ in the initial stage of the cloud. The time required for $95 \%$ scavenging of infinitely soluble gases increases from $20 \mathrm{~s}$ for $\alpha=1$ to $40 \mathrm{~min}$ for $\alpha=1 \times 10^{-4}$ [Jacob, 1985]. Even with $\alpha=1 \times 10^{-4}$, a stable cloud water $p \mathrm{H}$ of 4.16 is reached within 1 hour following cloud formation. Therefore $p \mathrm{H}$ is not a factor in the dependence of concentrations on $\alpha$ shown in Figure 10. Note that a stable $p \mathrm{H}$ would not be reached after 1 hour of cloud if $\alpha$ was lower than $10^{-4}$; however, as pointed out above, such low values are not likely in remote clouds.

Other soluble species, such as $\mathrm{CH}_{2} \mathrm{O}$ and $\mathrm{H}_{2} \mathrm{O}_{2}$, approach Henry's law equilibrium within minutes following cloud formation, even with $\alpha$ as low as $10^{-4}$ [Jacob, 1985]. Therefore the concentrations of these species show little dependence on $\alpha$. The concentration of $\mathrm{OH}(\mathrm{g})$ is also quite insensitive to $\alpha$, because gas-droplet exchange is not a major source or sink for this species. The only gas-phase species showing a strong dependence on $\alpha$ is $\mathrm{HO}_{2}(\mathrm{~g})$, whose lifetime in cloud is controlled by the rate of gas-droplet transfer (Figure 2). Concentrations of $\mathrm{HO}_{2}(\mathrm{~g})$ are 2.7 times higher for $\alpha=1 \times 10^{-4}$ than for $\alpha=1$. This dependence of the $\mathrm{HO}_{2}(\mathrm{~g})$ concentration on $\alpha$ is consistent with that previously predicted by Schwartz [1984].

The dependence of the $\mathrm{O}_{2}(-\mathrm{I})$ concentration on $\alpha$ follows the dependence of the $\mathrm{HO}_{2}(\mathrm{~g})$ source, but it is much weaker. This is partly because $\mathrm{O}_{2}(-\mathrm{I})$ is also produced by aqueousphase sources and partly because removal of $\mathrm{O}_{2}(-\mathrm{I})$ by the reaction $\mathrm{HO}_{2}+\mathrm{O}_{2}^{-}$is a second-order sink. The concentration of $\mathrm{OH}(\mathrm{aq})$ is weakly dependent on $\alpha$; this dependence is due to the flux of $\mathrm{OH}(\mathrm{g})$ to the droplets and the rate of the aqueous-phase source reaction $\mathrm{O}_{2}{ }^{-}+\mathrm{O}_{3}$. The depen- dence of the $\mathrm{HCOOH}$ concentration on $\alpha$ follows that of $\mathrm{OH}(\mathrm{aq})$.

The sensitivity of the chemistry to the rate of gas-droplet transfer was further explored by a series of simulations with different droplet radii ranging from 5 to $30 \mu \mathrm{m}$ (other conditions as in Table 1; liquid water content was held constant at $\left.5 \times 10^{-7} \mathrm{vol} / \mathrm{vol}\right)$. The continuum gas-droplet transfer flux varies as $\left(1 / a^{2}\right)$, and the noncontinuum correction to the flux is small when $\alpha=0.1$ (Figure 1). Changes in droplet radius and changes in $\alpha$ both affect only the rates of gas-droplet transfer; therefore they are interpreted in the same manner. Results are shown in Figure 11 for $\mathrm{OH}$ and $\mathrm{HO}_{2}$ species and for $\mathrm{HCOOH}_{T}$. The concentration of $\mathrm{OH}(\mathrm{aq})$ decreases by a factor of 3 as the droplet radius increases from $5 \mu \mathrm{m}$ to $30 \mu \mathrm{m}$; the concentration of $\mathrm{OH}(\mathrm{g})$ increases by $30 \%$ over this same range.

\section{Liquid Water Content}

The sensitivity of the chemistry to $L$ was explored by a series of simulations with $L$ ranging from $1 \times 10^{-7}$ to $1.5 \times$ $10^{-6} \mathrm{vol} / \mathrm{vol}$ (other model conditions as in Table 1). As $L$ increases, gas-droplet transfer fluxes increase because of the larger liquid water surface area. Further, the equilibrium partitioning of a soluble species between the gas phase and the aqueous phase is shifted towards the aqueous phase. Aqueousphase concentrations $(M)$ generally decrease because of the higher dilution; the $p \mathrm{H}$ of the cloud rises from 3.48 with $L=$ $1 \times 10^{-7} \mathrm{vol} / \mathrm{vol}$ to 4.61 with $L=1.5 \times 10^{-6} \mathrm{vol} / \mathrm{vol}$.

Results are shown in Figure 12 for $\mathrm{OH}$ and $\mathrm{HO}_{2}$ species and for $\mathrm{HCOOH}_{T}$. The $\mathrm{HO}_{2}(\mathrm{~g})$ concentration decreases rapidly with increasing $L$ because of the increase in the droplet sink. Scavenging of $\mathrm{HO}_{2}(\mathrm{~g})$ by the droplets is enhanced both

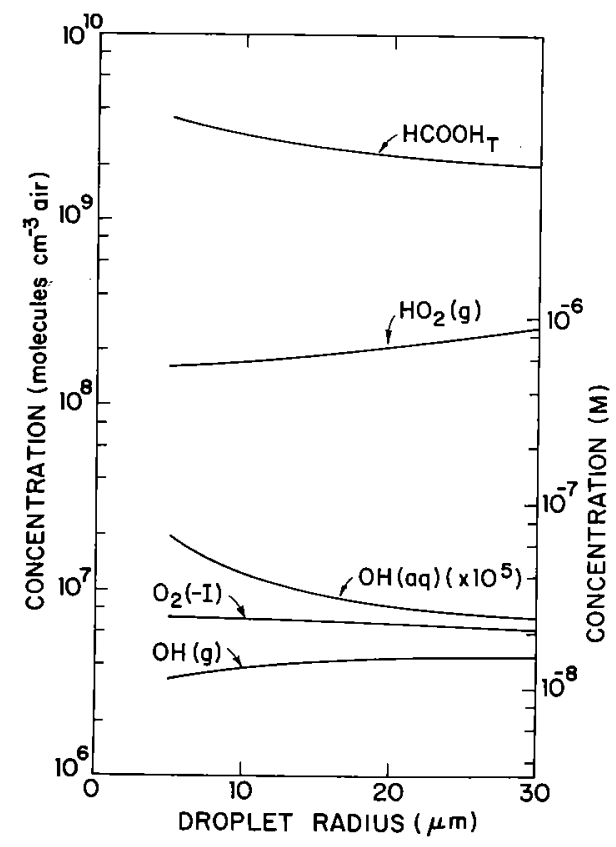

Fig. 11. Concentrations of $\mathrm{OH}, \mathrm{HO}_{2}$, and $\mathrm{HCOOH}_{T} 1$ hour after cloud formation, as a function of droplet radius (constant liquid water content). Other model conditions are those of Table 1. Gas-phase and $\mathrm{HCOOH}_{T}$ concentrations are in units of molecules per cubic centimeter of air (left-hand scale), and aqueous-phase concentrations are in units of moles per liter of water (right-hand scale). Both scales are equivalent (equation (14)). 


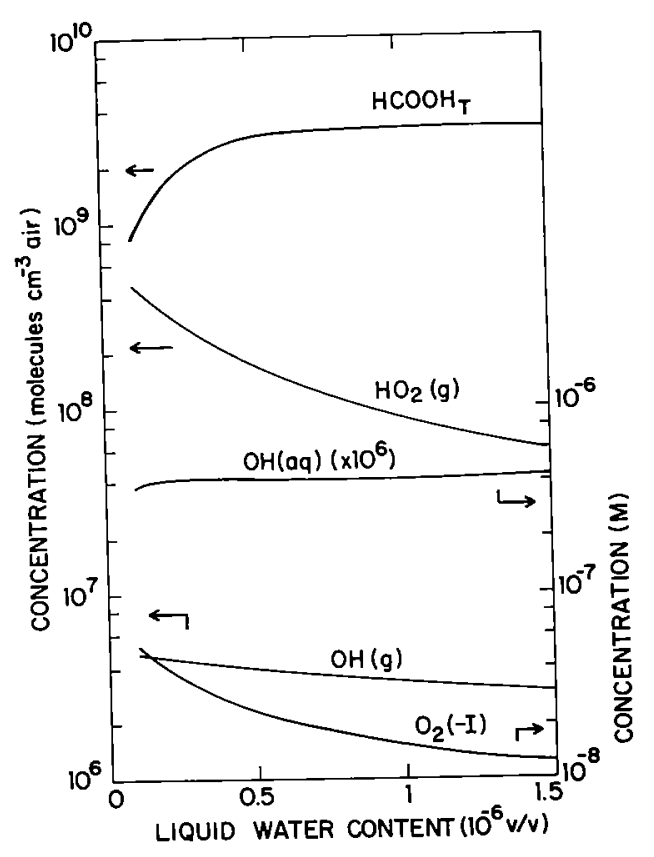

Fig. 12. Concentrations of $\mathrm{OH}, \mathrm{HO}_{2}$, and $\mathrm{HCOOH}_{T} 1$ hour after cloud formation, as a function of liquid water content (constant droplet radius). Other model conditions are those of Table 1. Gas-phase and $\mathrm{HCOOH}_{T}$ concentrations are in units of molecules per cubic centimeter of air (left-hand scale), and aqueous-phase concentrations are in units of moles per liter of water (right-hand scale). The two scaies are not equivalent because the liquid water content is not constant.

by the increase in the gas-droplet transfer flux and by the rise in $p \mathrm{H}$, which favors $\mathrm{HO}_{2}(\mathrm{aq})$ dissociation in the aqueous phase. The dissociation of $\mathrm{HO}_{2}(\mathrm{aq})$ enhances the $\mathrm{O}_{2}(-\mathrm{I})$ sink; therefore the $\mathrm{O}_{2}(-\mathrm{I})$ concentration $(M)$ decreases with increasing $L$. The concentration of $\mathrm{OH}(\mathrm{g})$ decreases slightly with increasing $L$, for two major reasons: (1) increased scavenging of $\mathrm{H}_{2} \mathrm{O}_{2}(\mathrm{~g})$ inhibits the $\mathrm{H}_{2} \mathrm{O}_{2}+h v$ source, and (2) transfer of $\mathrm{OH}(\mathrm{g})$ to the droplets is faster. The decrease in the concentration of $\mathrm{OH}(\mathrm{g})$ lowers the gas-phase source of $\mathrm{OH}(\mathrm{aq})$, but on the other hand, the aqueous-phase source of $\mathrm{OH}(\mathrm{aq})$ (RA27) rises because of the increase in $p \mathrm{H}$ (see above). These opposite effects balance one another, so that the $\mathrm{OH}(\mathrm{aq})$ concentration $(M)$ shows very little sensitivity to liquid water content. The concentration of $\mathrm{HCOOH}_{T}$ increases rapidly with increasing $L$ up to $5 \times 10^{-7} \mathrm{vol} / \mathrm{vol}$, because of enhanced scavenging of $\mathrm{CH}_{2} \mathrm{O}$ by cloud. The $p \mathrm{H}$ of the cloud is low, therefore $\mathrm{HCOOH}$ is stabilized by volatilization to the gas phase. For $L>5 \times 10^{-7} \mathrm{vol} / \mathrm{vol}$, however, volatilization of $\mathrm{HCOOH}$ to the gas phase is restricted both by the rise in $p \mathrm{H}$ and by the increasing amount of liquid water present; this increases the efficiency of the aqueous-phase sink, reaction $\mathrm{HCOO}^{-}+\mathrm{OH}$. As a result, the $\mathrm{HCOOH}_{T}$ concentration shows little dependence on $L$ above $5 \times 10^{-7} \mathrm{vol} / \mathrm{vol}$.

\section{CONCLUSIONS}

A detailed gas-phase/aqueous-phase cloud chemistry model has been developed which takes into account the radial dependence of the concentrations of short-lived aqueous-phase species. The model is applied to the study of $\mathrm{OH}$ chemistry in a remote marine tropical cloud. The main sources of $\mathrm{OH}(\mathrm{aq})$ are the aqueous-phase reactions $\mathrm{O}_{2}{ }^{-}+\mathrm{O}_{3}$ and $\mathrm{H}_{2} \mathrm{O}_{2}+h v$ and the absorption of $\mathrm{OH}(\mathrm{g})$. The main sinks are the oxidation of $\mathrm{H}_{2} \mathrm{C}(\mathrm{OH})_{2}, \mathrm{H}_{2} \mathrm{O}_{2}(\mathrm{aq})$, and $\mathrm{HCOO}^{-}$. The concentration of $\mathrm{OH}(\mathrm{aq})$ increases with increasing cloud water $p \mathrm{H}$ but shows little dependence on liquid water content, droplet radius, or sticking coefficient. The chemical lifetime of $\mathrm{OH}(\mathrm{aq})$ is of the order of $10^{-4} \mathrm{~s}$, which is too short to allow for mixing within the droplets. Therefore a strong $\mathrm{OH}(\mathrm{aq})$ concentration gradient exists between the interior and the surface of the droplets. The concentration of $\mathrm{OH}(\mathrm{aq})$ away from the droplet surface is given by an aqueous-phase chemical steady state independent of $\mathrm{OH}$ gas-droplet transfer.

Scavenging of $\mathrm{OH}(\mathrm{g})$ by cloud droplets must be modeled as a reversible process, that is, one cannot assume that the droplets behave as diffusion-limited sinks for $\mathrm{OH}(\mathrm{g})$. The $\mathrm{OH}$ flux is generally directed from the gas phase to the aqueous phase, but a net $\mathrm{OH}$ flux out of the droplets is found when aqueousphase production of $\mathrm{OH}(\mathrm{aq})$ is very rapid (for example, at high $p \mathrm{H})$. Cloud formation is found to cause a $25 \%$ decrease in the $\mathrm{OH}(\mathrm{g})$ concentration, mostly because scavenging of $\mathrm{HO}_{2}(\mathrm{~g})$ and $\mathrm{H}_{2} \mathrm{O}_{2}(\mathrm{~g})$ interrupts the gas-phase odd hydrogen cycle. The concentration of $\mathrm{OH}(\mathrm{g})$ in cloud shows little dependence on cloud water $p \mathrm{H}$, liquid water content, droplet radius, or sticking coefficient.

The effect of aqueous-phase radical chemistry on the $\mathrm{CH}_{4}$ oxidation chain in cloud has been investigated. The main feature of this chemistry is the rapid aqueous-phase production of $\mathrm{HCOOH}$; the efficiency of a cloud as a source of $\mathrm{HCOOH}$ is shown to be strongly dependent on cloud water $p H$. At $p \mathrm{H}<5$, $\mathrm{HCOOH}$ produced in the aqueous phase is volatilized to the gas phase, where it has a long lifetime against oxidation by $\mathrm{OH}(\mathrm{g})$. At $p \mathrm{H}>5$, however, $\mathrm{HCOOH}$ remains in the aqueous phase as $\mathrm{HCOO}^{-}$and is rapidly oxidized by $\mathrm{OH}(\mathrm{aq})$. Therefore clouds with $p \mathrm{H}>5$ are not efficient sources of $\mathrm{HCOOH}$. Production of $\mathrm{HCOOH}$ is most efficient at $p \mathrm{H} \approx 3.5$. The concentration of $\mathrm{HCOO}^{-}$is highest at $p \mathrm{H} \approx 5$. Concentrations of $\mathrm{HCOOH}$ species shows little dependence on droplet radius or sticking coefficient and little dependence on liquid water content above $5 \times 10^{-7} \mathrm{vol} / \mathrm{vol}$.

A novel mechanism has been proposed for the oxidation of $\mathrm{S}(\mathrm{IV})$ by $\mathrm{OH}(\mathrm{aq})$ in remote clouds. It is predicted from this mechanism that the intermediate $\mathrm{SO}_{5}{ }^{-}$does not propagate a $\mathrm{S}(\mathrm{IV})$ oxidation chain by the reaction $\mathrm{SO}_{5}{ }^{-}+\mathrm{HSO}_{3}{ }^{-}$but reacts instead with $\mathrm{O}_{2}{ }^{-}$to produce $\mathrm{HSO}_{5}{ }^{-}$(peroxymonosulfate). At cloud water $\mathrm{pH}$ values above $5, \mathrm{HSO}_{5}{ }^{-}$ is found to contribute about $35 \%$ of total cloud water sulfur (the remainder being contributed by $\mathrm{SO}_{4}{ }^{2-}$ ). At this date, no attempts have been made to determine $\mathrm{HSO}_{5}{ }^{-}$concentrations in cloud water samples. It is hoped that this model study will encourage such attempts.

Acknowledgments. S. C. Wofsy and M. J. Prather provided inspiration and many stimulating discussions. I thank J. A. Logan and M. B. McElroy for their careful review of the manuscript and C. Spivakovsky for her advice on the mathematics. Valuable discussions with M. R. Hoffmann, R. E. Huie, and C. J. Walcek are gratefully acknowlM. R. Hoffmann, R. E. Huie, and C. J. Walcek from the National Aeronautics and Space Administration (grant NAGW-731) and from the National Science Foundation (grant ATM-83-17009).

\section{REFERENCES}

Adams, G. E. and J. W. Boag, Spectroscopic studies of reactions of the OH radical, Proc. Chem. Soc. London, 112, 1964.

Adewuyi, Y. G., S.-Y. Cho, R.-P. Tsay, and G. R. Carmichael, Importance of formaldehyde in cloud chemistry, Atmos. Environ., 18, $2413-2420,1984$. 
ida-
Anbar, M., and P. Neta, A compilation of specific bimolecular rate constants for the reactions of hydrated electrons, hydrogen atoms and hydroxyl radicals with inorganic and organic compounds in aqueous solution, Int. J. Appl. Radiat. Isot., 18, 493-523, 1967.

Atkinson, R., and A. C. Lloyd, Evaluation of kinetic and mechanistic data for modeling of photochemical smog, J. Phys. Chem. Ref. Data, 13, 315-444, 1984.

Ayers, G. P., and J. L. Gras, The concentration of ammonia in southern ocean air, J. Geophys. Res., 88, 10,655-10,659, 1983.

Baxendale, J. H., M. D. Ward, and P. Wardman, Heats of ionization of $\mathrm{HO}_{2}$ and $\mathrm{OH}$ in aqueous solution, Trans. Farad. Soc., 67, 2532$2537,1971$.

Behar, D., G. Czapski, and I. Duchovny, Carbonate radical in flash photolysis and pulse radiolysis of aqueous carbonate solutions, $J$. Phys. Chem., 74, 2206-2210, 1970.

Bell, R. P., The reversible hydration of carbonyl compounds, Adv. Phys. Org. Chem., 4, 1-29, 1966.

Bielski, B. H. J., Reevaluation of the spectral and kinetic properties of $\mathrm{HO}_{2}$ and $\mathrm{O}_{2}{ }^{-}$free radicals, Photochem. Photobiol., 28, 645-649, 1978.

Bothe, E., and D. Schulte-Frohlinde, Reaction of dihydroxymethyl radical with molecular oxygen in aqueous solution, $Z$. Naturforsch. B, Anorg. Chem. Org. Chem., 35, 1035-1039, 1980.

Boyce, S. D., and M. R. Hoffmann, Kinetics and mechanism of the formation of hydroxymethanesulfonic acid at low $p \mathrm{H}, J$. Phys. Chem., 88, 4740-4746, 1984.

Buhler, R. E., J. Staehelin, and J. Hoigne, Ozone decomposition in water studied by pulse radiolysis, $1, \mathrm{HO}_{2} / \mathrm{O}_{2}{ }^{-}$and $\mathrm{HO}_{3} / \mathrm{O}_{3}{ }^{-}$as intermediates, J. Phys. Chem., 88, 2560-2564, 1984.

Calvert, J. G., and W. R. Stockwell, Mechanisms and rates of the gas-phase oxidations of sulfur dioxide and nitrogen oxides in the atmosphere, in $\mathrm{SO}_{2}, \mathrm{NO}$ and $\mathrm{NO}_{x}$ Oxidation Mechanisms: Atmospheric Considerations, Acid Precipitation Ser., vol. 3, edited by J. G. Calvert, pp. 1-62, Butterworth, Stoneham, Mass., 1984.

Cavanagh, L. A., C. F. Schadt, and E. Robinson, Atmospheric hydrocarbon and carbon monoxide measurements at Point Barrow, Alaska, Environ. Sci. Technol., 3, 251-257, 1969.

Chameides, W. L., The photochemistry of a remote marine stratiform cloud, J. Geophys. Res., 89, 4739-4755, 1984.

Chameides, W. L., Reply, J. Geophys. Res., 90, 5865, 1985.

Chameides, W. L., and D. D. Davis, The free radical chemistry of cloud droplets and its impact upon the composition of rain, $J$. Geophys. Res., 87, 4863-4877, 1982.

Chameides, W. L., and A. Tan, The two-dimensional diagnostic model for tropospheric $\mathrm{OH}$ : An uncertainty analysis, $J$. Geophys. Res., 86, 5209-5223, 1981.

Chao, J., and B. J. Zwolinski, Ideal gas thermodynamic properties of methanoic and ethanoic acids, J. Phys. Chem. Ref. Data, 7, 363-377, 1978.

Chen, S., V. W. Cope, and M. Z. Hoffman, Behavior of $\mathrm{CO}_{3}{ }^{-}$radicals generated in the flash photolysis of carbonatoamines complexes of cobalt(III) in aqueous solution, J. Phys. Chem., 77, 1111-1116, 1973.

Christensen, H., K. Sehested, and H. Corfitzen, Reactions of hydroxyl radicals with hydrogen peroxide at ambient and elevated temperatures, J. Phys. Chem., 86, 1588-1590, 1982.

Damschen, D. E., and L. R. Martin, Aqueous aerosol oxidation of nitrous acid by $\mathrm{O}_{2}, \mathrm{O}_{3}$, and $\mathrm{H}_{2} \mathrm{O}_{2}$, Atmos. Environ., 17, 2005-2011, 1983.

Daniels, M., Radiolysis and photolysis of the aqueous nitrate system. Adv. Chem. Ser., 81, 153-163, 1968.

Deister, U., V. R. Neeb, J. Helas, and P. Warneck, The equilibrium of $\mathrm{CH}_{2}[\mathrm{OH}]_{2}+\mathrm{HSO}_{3}{ }^{-} \rightleftarrows \mathrm{CH}_{2}[\mathrm{OH}] \mathrm{SO}_{3}{ }^{-}$in aqueous solution: Temperature dependence and importance in cloud, J. Phys. Chem., in press, 1986.

Devuyst, E. A. P., V. A. Ettel, and M. A. Mosoiu, An oxidant of unexpected utility, Chemtech, 426-427, 1979.

Dogliotti, L., and E. Hayon, Flash photolysis of persulfate ions in aqueous solutions. Study of the sulfate and ozonide radical ions, $J$. Phys. Chem., 71, 2511-2516, 1967.

Dogliotti, L., and E. Hayon, Flash photolysis study of sulfite, thiocyanate and thiosulphate ions in solution, J. Phys. Chem., 72, 1800 $1807,1968$.

Edwards, J. O., Inorganic Reaction Mechanisms, p. 84, W. A. Benjamin, New York, 1964.

Edwards, J. O., and J. J. Mueller, The rates of oxidation of nitrite ion by several peroxides, Inorg. Chem., 1, 696-699, 1962.
Fortnum, D. H., C. J. Battaglia, S. R. Cohen, and J. O. Edwards, The kinetics of the oxidation of halide ions by monosubstituted peroxides, J. Am. Chem. Soc., 82, 778-782, 1960.

Fuchs, N. A., and A. G. Sutugin, High-dispersed aerosols, in International Reviews of Aerosol Physics and Chemistry, vol. 2, edited by G. M. Hidy and J. R. Brock, pp. 1-60, Pergamon, New York, 1971.

Gill, P. S., T. E. Graedel, and C. J. Wechsler, Organic films on atmospheric aerosol particles, fog droplets, cloud droplets, raindrops, and snowflakes, Rev. Geophys., 21, 903-920, 1983.

Gillette, D. A., and I. H. Blifford, Jr., Composition of tropospheric aerosols as a function of altitude, J. Atmos. Sci., 28, 1199-1210, 1971.

Glasstone, S., K. J. Laidler, and H. Eyring, The Theory of Rate Processes, p. 523, McGraw-Hill, New York, 1941.

Graedel, T. E., and K. I. Goldberg, Kinetic studies of raindrop chemistry, 1, Inorganic and organic processes, J. Geophys. Res., 88, $10,865-10,882,1983$

Graedel, T. E., and C. J. Wechsler, Chemistry within aqueous aerosols and raindrops, Rev. Geophys., 19, 505-539, 1981.

Gratzel, M., A. Henglein, and S. Taniguchi, Pulsradiolytische Beobachtungen uber die reduktion des $\mathrm{NO}_{3}{ }^{-}$-Ions und uber Bildung und Zerfall des persalpetrigen Saure in wassriger Losung, Ber. Bunsenges. Phys. Chem., 74, 292-298, 1970.

Hagesawa, K., and P. Neta, Rate constants and mechanisms of reaction for $\mathrm{Cl}_{2}{ }^{-}$radicals, J. Phys. Chem., 82, 854-857, 1978.

Hales, J. M., and D. R. Drewes, Solubility of ammonia in water at low concentrations, Atmos. Environ., 13, 1133-1147, 1979.

Hayon, E., A. Treinin, and J. Wilf, Electronic spectra, photochemistry, and autoxidation mechanism of the sulfite-bisulfite-pyrosulfite systems; The $\mathrm{SO}_{2}{ }^{-}, \mathrm{SO}_{3}{ }^{-}, \mathrm{SO}_{4}{ }^{-}$, and $\mathrm{SO}_{5}{ }^{-}$radicals, J. Am. Chem. Soc., 94, 47-57, 1972.

Hegg, D. A., The importance of liquid-phase oxidation of $\mathrm{SO}_{2}$ in the troposphere, J. Geophys. Res., 90, 3773-3779, 1985.

Hoffmann, M. R., Thermodynamic, kinetic, and extrathermodynamic considerations in the development of equilibrium models for aquatic systems, Environ. Sci. Technol., 15, 345-353, 1981.

Hoffmann, M. R., On the kinetics and mechanism of oxidation of aquated sulfur dioxide by ozone, Atmos. Environ., in press, 1986.

Hoffmann, M. R., and J. G. Calvert, Chemical transformation modules for Eulerian acid deposition models, vol. 2, The aqueous-phase chemistry, Rep. EPA/600/3-85/017, Environ. Prot. Agency, Research Triangle Park, N. C., 1985.

Hoigne, J., and $\mathrm{H}$. Bader, Rate constants of reactions of ozone with organic and inorganic compounds in water, 1, Non-dissociating organic compounds, Water Res., 17, 173-183, 1983a.

Hoigne, J., and H. Bader, Rate constants of reactions of ozone with organic and inorganic compounds in water, 2, Dissociating organic compounds, Water Res., 17, 185-194, $1983 b$.

Hoigne, J., H. Bader, W. R. Haag, and J. Staehelin, Rate constants of reactions of ozone with organic and inorganic compounds in water, 3. Inorganic compounds and radicals, Water Res., 19, 993-1004, 1985 .

Huie, R. E., and P. Neta, Chemical behavior of $\mathrm{SO}_{3}{ }^{-}$and $\mathrm{SO}_{5}{ }^{-}$ radicals in aqueous solutions, $J$. Phys. Chem., 88, 5665-5669, 1984.

Jacob, D. J., Comment on "The photochemistry of a remote marine stratiform cloud" by William L. Chameides, J. Geophys. Res., 90, $5864,1985$.

Jacob, D. J., and M. R. Hoffmann, A dynamic model for the production of $\mathrm{H}^{+}, \mathrm{NO}_{3}{ }^{-}$, and $\mathrm{SO}_{4}{ }^{2-}$, in urban fog, J. Geophys. Res., $88,6611-6621,1983$.

Jacob, D. J., J. W. Munger, J. M. Waldman, and M. R. Hoffmann, The $\mathrm{H}_{2} \mathrm{SO}_{4}-\mathrm{HNO}_{3}-\mathrm{NH}_{3}$ system at high humidities and in fogs, 1 , Spatial and temporal patterns in the San Joaquin Valley of California, J. Geophys. Res., 91, 1073-1088, 1986a.

Jacob, D. J., J. M. Waldman, J. W. Munger, and M. R. Hoffmann, The $\mathrm{H}_{2} \mathrm{SO}_{4}-\mathrm{HNO}_{3}-\mathrm{NH}_{3}$ system at high humidities and in fogs, 2, Comparison of field data with thermodynamic calculations, J. Geophys. Res., 91, 1089-1096, $1986 b$.

Jayson, G. G., B. J. Parsons, and A. J. Swallow, Some simple, highly reactive, inorganic chlorine derivatives in aqueous solution, Trans. Farad. Soc., 69, 1597-1607, 1973.

Jet Propulsion Laboratory, Chemical kinetics and photochemical data for use in stratospheric modeling, Evaluation 6,JPL Publ. 83-62, California Institute of Technology, Pasadena, 1983.

Keene, W. C., J. N. Galloway, and J. D. Holden, Jr., Measurement of weak organic acidity in precipitation from remote areas of the world, J. Geophys. Res., 88, 5122-5130, 1983. 
Klaning, U. K., K. Sehested, and J. Holcman, Standard Gibbs free energy of folution; Rate constants for the reaction $\mathrm{ClO}_{2}^{-}+\mathrm{O}_{3} \rightleftarrows \mathrm{O}_{3}{ }^{-}+\mathrm{ClO}_{2}, J$ Phys. Chem., 89, 760-763, 1985.

Kok, G. L S. N. Gitlin, and A. L Lazrus, Kinetics of the formation and decomposition of hydroxymethanesulfonate, J. Geophys. Res. 91, 2801-2804, 1986

Kyrki, J., Caro's acid and its thermal hydrolysis in acid and alkaline .

W. The Oxidation States of the Elements and their Poten列, pp. 45, 128, Prentice-Hall, New York, 1952

Ledbury, W., and E. W. Blair, The partial formaldehyde vapour pressolutions of formaldehyde, II, J. Chem. Soc., 127 2832-2839, 1925.

Lee, Y. N., and S. E. Schwartz, Reaction kinetics of nitrogen dioxide , $848,1981$.

and S. E Schwartz, In-cloud and below-cloud scavLevine, S. Z., and S. E. Schwart, Inos. Environ., 16, 1725-1734, 1982. enging of nitric acid vapor, Atmos. Environ., Lind, J., and T. E. Eriksen, Pulse radiolys-181, 1975. acid, Radiochem. Radioanal. Lett., 21,17 determinations for aqueous Lind, J. A., and G. L. Kok, Henry's law determinations for and persolutions of hydrogen peroxide, methylhydroperoxid oxyacetic acid, J. Geophys. Res., $91,7889-7895,1986$. Logan, J. A., M. J. Prather, S. C. Wofsy, and M. B. McElroy, Tropo-
spheric chemistry: A global perspective, J. Geophys. Res., 86, $7210-$ $7254,1981$.

Maroulis, P. J., A. L. Torres, A. B. Goldberg, and A. R. Bandy, Atmospheric $\mathrm{SO}_{2}$ measurements on project GAMETAG, J. Geophys. Res., 85, 7345-7349, 1980.

Maruthamuthu, P., and P. Neta, Radiolytic chain decomposition of peroxomonophosphoric and peroxomonosulfuric acids, $J$. Phys. Chem., 81, 937-940, 1977.

Maruthamuthu, P., and P. Neta, Phosphate radicals, Spectra, acidbase equilibria, and reactions with inorganic compounds, $J$. Phys. Chem., 82, 710-713, 1978.

McArdle, J. V., and M. R. Hoffmann, Kinetics and mechanism of the oxidation of aquated sulfur dioxide by hydrogen peroxide at low pH, J. Phys. Chem., 87, 5425-5429, 1983.

McElroy, W. J., The aqueous oxidation of $\mathrm{SO}_{2}$ by $\mathrm{OH}$ radicals, Atmos. Environ., 20, 323-330, 1986

Aunger, J. W., D. J. Jacob, and M. R. Hoffmann, The occurrence of bisulfite-aldehyde addition products in fog- and cloudwater, $J$. Atmos. Chem., 1, 335-350, 1984.

Munger, J. W., C. Tiller, and M. R. Hoffmann, Identification of hyC. Tiler, and Mcience, 231, 247-249, 1986. droxymethanesulfonate in fogwater, Science, 231, 247-249. Tables, 2nd National Bureau of Standards, JANAF Thermody, Washington, D. C.,

1971. National Research Councington, D. C., 1984.

for Action, National Academ Klett, Microphysics of Clouds and PrePruppacher, H. R., 421, D. Reidel, Hingham, Mass., 1978. cipitation, pp. 133, 421, D. Reidel, Hinghal reactions of aqueous nitric acid, Diss. Abstr. Int. B, 38, 5968, 1978.

Diss. Abstr. Int. B, $38,5968,1978$. Richtmeyer, R. D., Difference Methods Jor

101, Wiley-Interscience, New York, 1957 .

Ross, A. B., and P. Neta, Rate constants for reactions of radicals in aqueous solution, Rep.

Commerce, Washington, D. C., 1979 .

Rudolph, J., and D. H. Ehhalt, Measurements of $C_{2}-C_{5}$ hydrocarbons over the North Atlantic, J. Geophys. Res., 86,1 , M. Prospero, MethSaltzman, E. S., D. L. Savoie, R. G. Zika, and J. M. Prospero, Methane sulfonic acic $10,902,1983$.

Schwartz, S. E., Gas- and aqueous-phase chemistry of $\mathrm{HO}_{2}$ in liquid water clouds, J. Geophys. Res., 89, 11,589-11,598, 1984.

Schwartz, S. E., Mass-transport considerations pertinent to aqueousphase reactions of gases in liquid-water clouds, in Chemistry of Multiphase Atmospheric Systems, edited by W. Jaeschke, vol. G6, Mu 415-471, Springer-Verlag, New York, 1986.

p. 415-471, Springer chwartz, $\mathrm{S}$. E., an J . E. Fin liquid droplets: application to oxidation (15, 1129-1144, 1981.

Schwartz, S. E., and W. H. White, Solubility equilibria of the nitrogen oxides and oxyacids in aqueous solution, Adv. Environ. Sci. Eng., 4, $1-45,1981$.

Rasmussen, and $\mathrm{H}$. Fricke, Rate constants of $\mathrm{OH}$ with $\mathrm{HO}_{2}, \mathrm{O}_{2}{ }^{-}$, and $\mathrm{H}_{2} \mathrm{O}_{2}{ }^{+}$from hydrogen peroxide formation in pulse-irradiated oxygenated water, J. Phys. Chem., 72, 626-631, 1968.

Sehested, K., J. Holcman, and E. J. Hart, Rate constants and products of the reactions of $e_{-}^{-}, \mathrm{O}_{2}^{-}$, and $\mathrm{H}$ with ozone in aqueous solutions, J. Phys. Chem., 87, 1951-1954, 1983.

. Jolcman, E. Bjergbakke, and E. J. Hart, A pulse radiolytic study of the reaction $\mathrm{OH}+\mathrm{O}_{3}$ in aqueous medium, $J$. Phys. Chem., 88, 4144-4147, 1984.

Peigneur, $C$ and $P$. Saxena, A study of atmospheric acid formation in different environments, Atmos. Environ., I8, 2109-2124, 1984.

different of pollutants in stratus clouds: Application to nocturnal acid forpol pechnol., 19, 821-828, 1985.

Shapiloy, O. D., and Y. L. Kostyukovskii, Reaction kinetics of hyhapilov, O. D., and Y. L. Kostyukid in aqueous solutions, Kinet. Katal, 15, 1065-1067, 1974

Katal., 15, 1065-1067, Martell, Stability constants of metal-ion complexes, Spec. Publ. Chem. Soc., 17, 357, 1964.

plexes, Spec. Pnd G. A. Dawson, Tropospheric light alcohols, car-

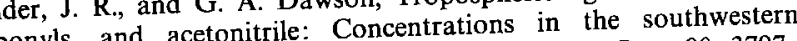
United States and Henry's law data, J. Geophys. Res., 90, 37973805,1985 .

Sorensen, P. E., and V. S. Andersen, The formaldehyde-hydrogen sulphite system in alkaline aqueous solution: kinetics, mechanism, and

and equilibria, Acta Hoigne, Decomposition of ozone in water: Rate of initiation by hydroxide ions and hydrogen peroxide, Environ. Sci. Technol., 16, 676-681, 1982.

Tochesition in water studied by pulse radiolysis, $2, \mathrm{OH}$ and $\mathrm{HO}_{4}$ as chain intermediates, J. Phys. Chem., 88, 5999-6004, 1984.

mediates of formation of peroxymonosulfate $\left(\mathrm{HSO}_{5}{ }^{-}\right)$and the standard electrode potential of the peroxymonosulfate-bisulfate couple, $J$. Chem. Thermodyn., 14, 337-344, 1982.

Stockwell, W. R., and J. G. Calvert, The mechanism of $\mathrm{NO}_{3}$ and HONO formation in the nighttime chemistry of the urban atmosphere, J. Geophys. Res., 88, 6673-6682, 1983.

spher, J. Geophida-

$\mathrm{Su}$, F., J. G. Calvert, and J. H. Shaw, Mechanism of the phot 1979. tion of gaseous formaldehyde, J. Phys. Chem., $83,3185-3191,1979$.

Thomas, J. R., and K. U. Ingold, Determination of rate constants for the self-reactions of peroxy radicals by electron spectroscopy, Adv. Chem. Ser., 75, 258-268, 1968 . $113,1970$.

Vierkorn-Rudolph, B., K. Bachmann, and B. Schwarz, Vertical profiles of hydrogen chloride in the troposphere, J. Atmos. Chem., 2, $47-63,1984$.

Wagman, D. D., W. H. Evans, V. B. Parker, R. H. Schumm, I. Halow, S. M. Bailey, K. L. Churney, and R. L. Nuttall, The NBS tables of ( chemical thermodynamic propertes in SI units, J. Phys. Chem. Ref. and $\mathrm{C}_{1}$ and $\mathrm{C}_{2}$ organic substanc

Data Suppl., 11, suppl. 2, 1982. revisited, Acc. Chem. Res., 8, 125-131, Wallin

1975. Weeks, J. L., and J. Rabani, The pulse radiol spectrum and mechanism; carbonate solutions, 1, Transient Chem., 70, 2100-2106, 1966.

II, $p \mathrm{~K}$ for OH radicals, J. Bielski, Kinetics of the interaction of $\mathrm{HO}_{2}$ Weinstein, J., and $\mathrm{B}$. H. J. Bielski, Keroxide; The Haber-Weiss reac. Soc, 101, 58-62,1979.

tion, J. Am. Chem. Soc., 101, 58-62, 1979. Zetzsch, C., and F. Stuhl, Rate constants for reactions of OH with carbonic acids, in Proceedings of 2nd European Symposium on Physico-Chemical Behavior of At

D. Jacob, Center for Earth and Planetary Physics, Harvard UniverDity, Ja Oxford Street, Cambridge, MA 02138

(Received December 17, 1985; revised May 6, 1986; accepted May $15,1986$. 